Historic, Archive Document

Do not assume content reflects current scientific knowledge, policies, or practices. 



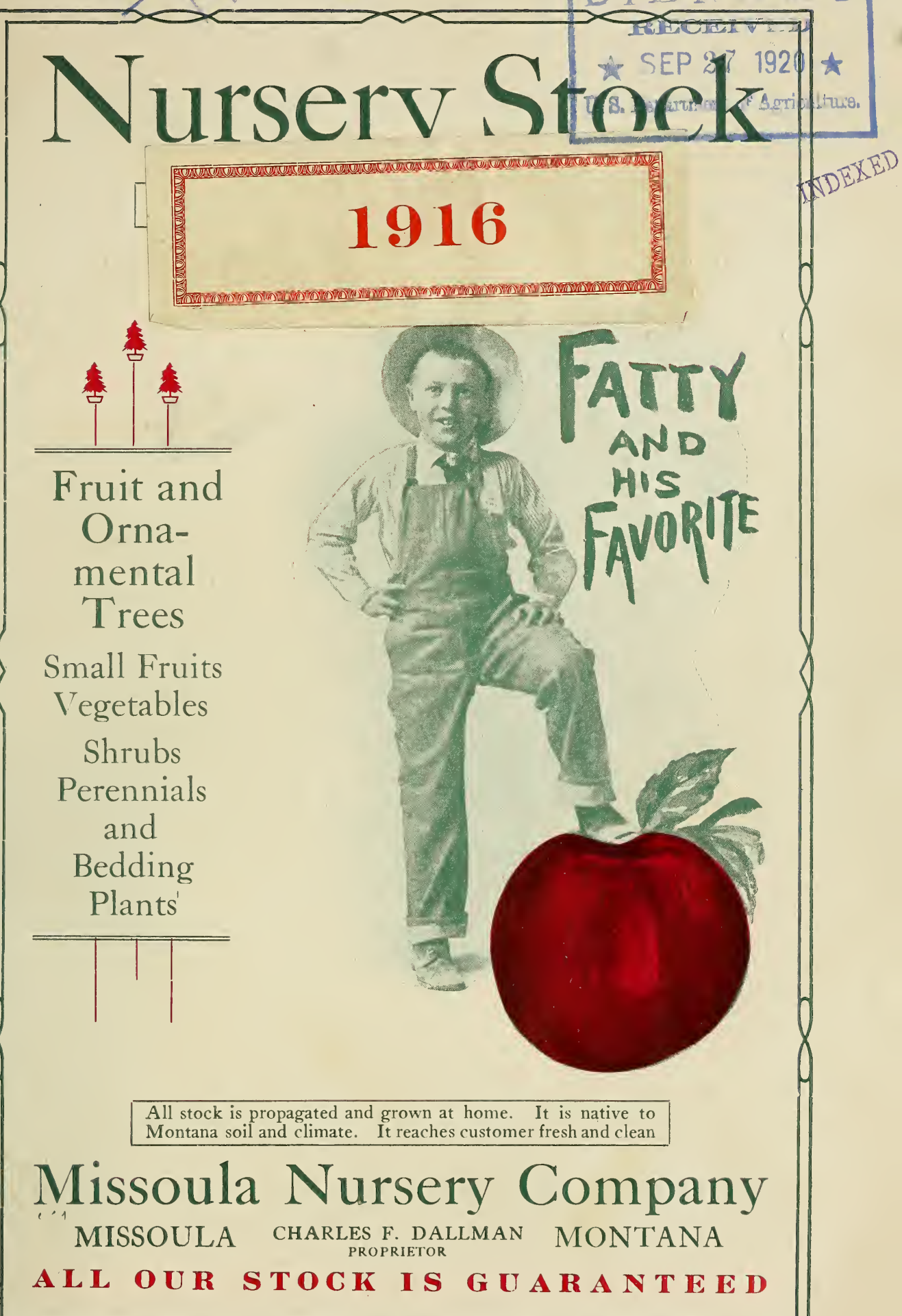

\section{Missoula Nursery Company MISSOULA CHARLES F. DALLMAN MONTANA

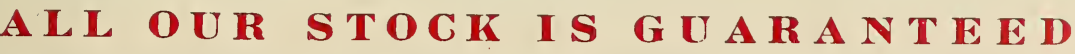




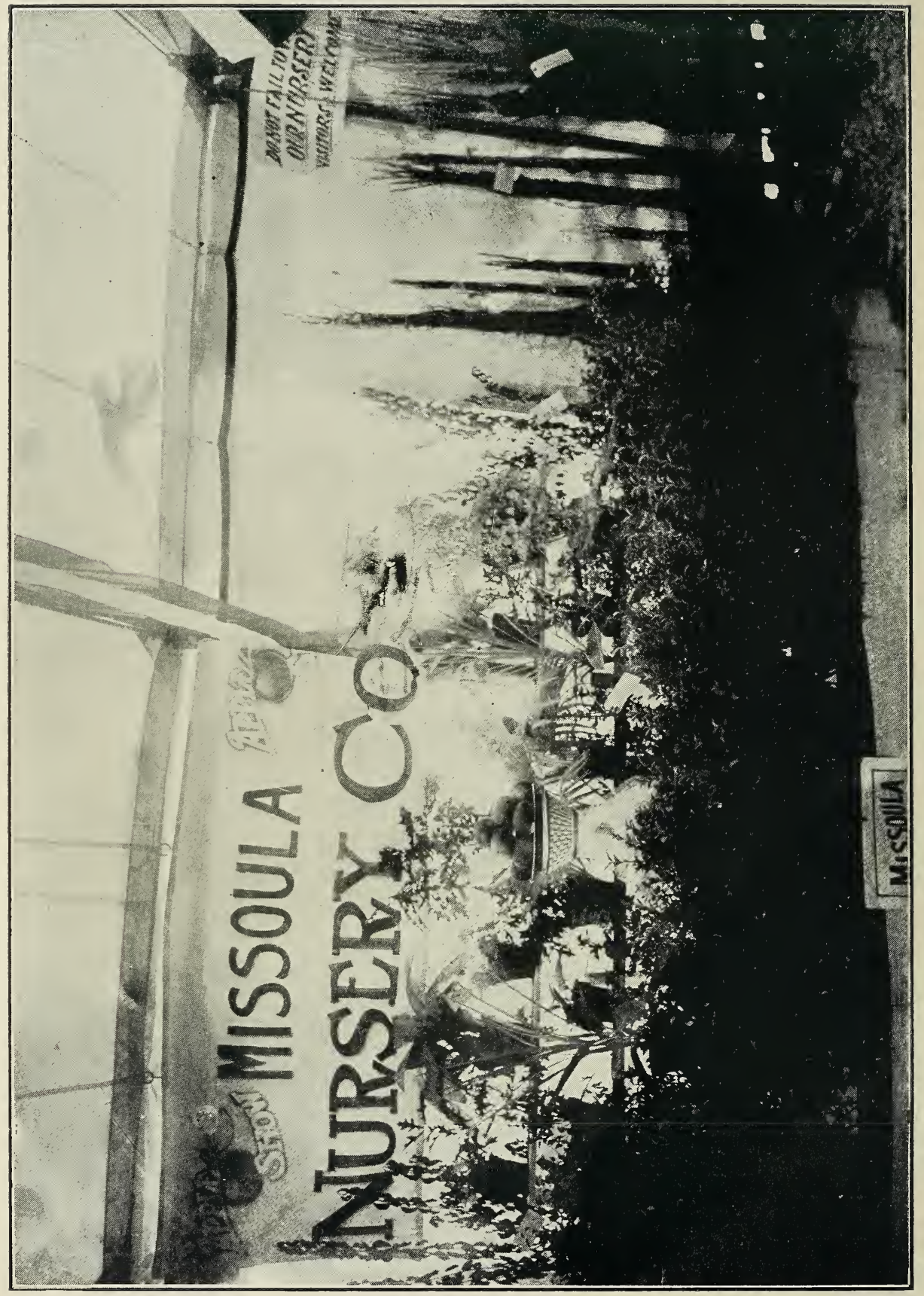




\section{GECTION OF NOME\&CLATURE}

\section{O N T E N T S}

Page.

Charles F. Dallman, Proprietor-Frontispiece.... 1

"Montana Grown Trees for Montana Plantters"

Terms

Transplanting Directions

Pruning, Irrigation, etc. ……………................. 4-5

Distance for Planting and Numbering Trees to Acre

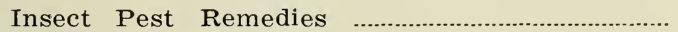

The Apple "Missoula" ............................................... 10

Testimonials ……............................................... 11-13

Apples-different varieties ………......................... 14-18

Testimonials ……...................................................... 18-19

Pears …................................................................ 20

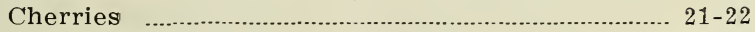

Testimonials ………................................................. 22-23

Plums and Prunes ..................................................... 24-25

Apricots, Quinces and Peaches.......................... 25

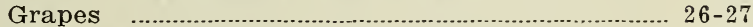

Currants and Their Culture

Gooseberries and Testimonials............................ 28-29

Raspberries …........................................................... 29-30

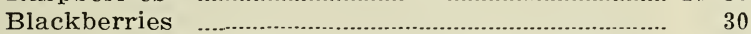

Loganberries, Dewberries and Strawberries...... 31-32

Garden Roots-Rhubarb, Horseradish, etc........ 33-34

Shade Trees-varieties and prices........................... 36-39

Hedge Plants ...................................................... 39

Flowering Shrubs .................................................. 40-41

Hardy Ornamental Climbing Vines.................... 41-42

Roses-varieties and description........................... 42-45

Hardy Perennial Plants..................................... 46-47

Plant Department-hints and suggestions.......... 48-51

Bedding Plants ………........................................... 52-56

Flowering Plants in Pots..................................... 57-59

Palms, Ferns and Bulbs......................................... 60-62

Cut Flower Department................................................. 64

Testimonials ……..................................................... 64-65

Transplanted Vegetable Plants............................... 66

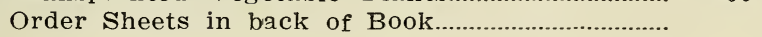




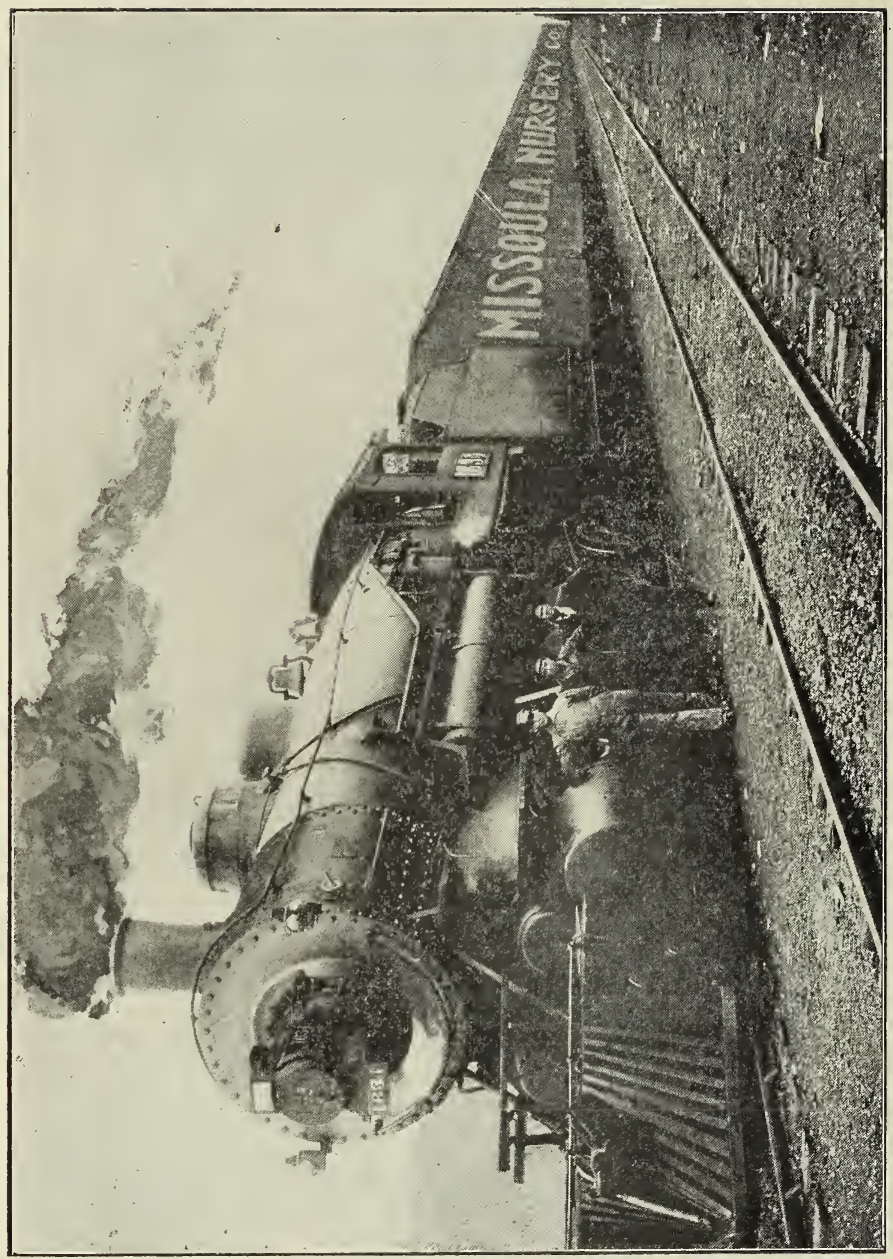

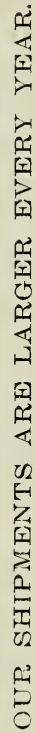




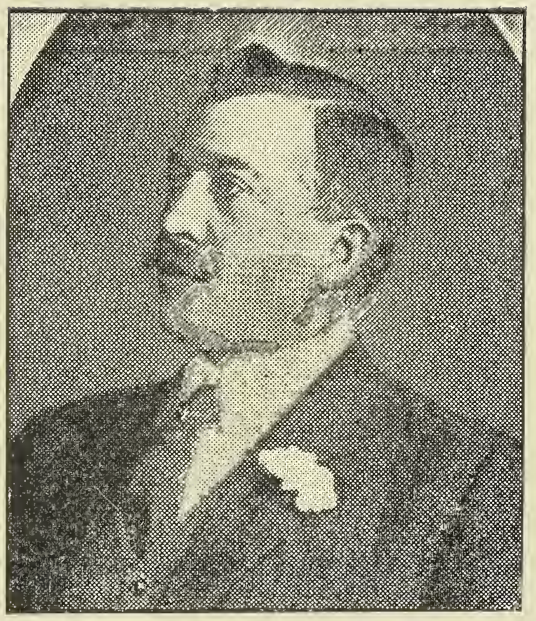

CHARLES F. DALLMAN 


\section{"Montana Grown Trees for Montana Planters."}

To the Fruitgrowers of the Pacific Northwest.

GREETING:-In 1892, when we started the above-the first nursery in Nontana-with a very limited list of apple grafts and small fruit cuttings, we adopted as our motto, "Montana Grown Trees for Montana Planters." By it we stand, and by it we have grown from a small block of a few hundred to a full-fledged nursery of as many hundred thousand high grade and giltedged fruit and ornamental trees and plants-65 acres of solid general nursery stock, all grown under the best possible soil and climatic conditionsall grown from selected pedigree Montana material, from hardy adapted varieties; in fact, "Montana Grown Trees for Montana Planters." Our greenhouses for the growing of cut flowers now cover more ground space than our little nursery in the hills in 1892. At no time during the past 21 years have we been fully able to supply the demand for home-grown trees. For this season we have a large and magnificent supply of high grade, true-to-name line of nursery stock, and we can supply all of the varieties mentioned in this catalogue. Orders by mail will receive careful and considerate treatment.

Thanking you for the patronage so generously extended to us in the past, we solicit a continuation of your future orders. We extend a cordial invitation to all interested in fruitgrowing to visit and inspect our nurseries, which are located two and a half miles southwest of the City of Missoula. Respectfully, MISSOULA NURSERY CO.

\section{TERMS}

We guarantee satisfaction to our patrons.

We warrant all our stock to be in good condition, sound and healthy.

All stock prepaid at prices named in this catalogue. We make no charge for packing or drayage.

All orders from unknown correspondents must be accompanied with CASH or satisfactory references.

When varieties named, or size, cannot be furnished, we reserve the right to send others similar or better in their place, unless instructed not to do so.

All our stock is shipped with CERTIFICATE OF INSPECTION by the proper state official, showing that our stock is free from San Jose Scale and other dangerously injurious insect pests and diseases.

Immediate notice should be giver of any error or omission in filling an crder. While we exercise great care, and mistakes are rare, we hold ourselves ready to rectify all mistakes or give satisfactory explanation if claim is made within ten days.

We warrant all our stock to be true to name and label, with the agreement that should any prove not true to rame we will replace free of charge with stock that is. But it is mutually agreed between the purchaser and ourselves that our guarantee of genuineness shall in no case make us liable for a greater sum than that originally paid for the stock that may prove untrue.

Note what planters say about our goods. 


\title{
TRANSPLANTING DIRECTIONS
}

\author{
Issued by the Missoula Nursery Co., Missoula, Montana. \\ Read Carefully and Preserve for Future Reference.
}

After receiving, give your stock good care. Do not expect to have a cow pasture and orchard in the same enclosure; it is not a success. Cultivate your orchard when young. Do your best to follow these simple directions. It will require some labor-nothing good comes without it. You can not reap without you sow. Follow directions closely and fruit in abundance will be your reward.

In presenting these instructions to our patrons, we would earnestly request that they give the most careful attention to the details. Years of experience have taught us that the public loses nursery stock because they reglect it; and we take the precaution to send a copy of our Transplanting Directions to every customer, so that none may claim they do not know how to plant and care for their stock.

We guarantee to deliver the stock in good condition, and could we plant and care for it the first three months, would willingly insure the growth of every tree and plant set out. Our agents report that very few people pay any attention to transplanting directions. Anything that has to be cultivated in the earth can no more live without nourishment and care than can a human being.

\section{CARE OF TREES ON ARRIVAL}

If you are ready for them, proceed to plant at once; if not, with a possibility of any delay, unpack carefully without exposing the roots to cold or air, dig a trench about 18 inches deep in a well-drained spot, carefully covering all the roots; if dry, water copiously. Trees can thus remain in trenches till you are ready to plant in the orchard. If frozen when received, bury the trees, without unpacking, in well-drained ground, or place in a cellar to thaw out gradually without exposure to air or light. If shriveled and dry from delay in transit, take out from package and bury in a slanting position all but the tops, soak well with water and let them remain until they regain their plump appearance; then plant.

\section{PREPARATION OF THE SOIL}

For fruit trees the condition of the soil must be such as would be adapted to grow farm crops successfully.

\section{PREPARING TREES FOR PLANTING}

The broken or mutilated portions of the roots must be cut off, so as to leave the ends smooth and sound, and the ends of all the other roots should be pruned. From these ends the new fibrous roots usually start.

\section{PLANTING}

The hole must be large enough to receive the roots freely, without cramping or bending them from their natural position; the larger the better. Let the tree be an inch or two deeper than it stood in the nursery (the old mark can be readily discerned). The tree being held upright, the finest and best earth from the surface should be worked carefully among the roots with the fingers, filling every space and bringing every root in contact with it. Set the tree as firm as a post, but leave the surface filling light and loose. 


\section{PRUNING}

The stems should now be put in condition for the formation of the top by removing all the limbs to the point where it is desired to have the top; then cut back each remaining limb, leaving from four to six buds of last season's growth. In the absence of any limbs suitable to form a top, cut the tree down to the requisite height, leaving the dormant buds to make the top.

The necessity of pruning vigorously at time of setting is generally a very ungrateful one to the planter, as it injures for a time the appearance of the tree to an unpracticed eye. It should, however, be unhesitatingly performed, all the branches to the extent of at least one-half the length of the previous vear's growth being removed. Care should also be used to give the proper form to the tree. The head may be left high or low, as the taste of the planter may prefer, or as the nature of the tree in some cases may require.

The requirements of pruning vary somewhat, according to the kind of tree; we prefer, however, low training for all trees. The pruning should be àne each year, so that no necessity may arise for cutting large limbs. Care must also be used to keep the head of the tree open and well balanced, cutting the limbs which may be superfluous.

Trees should be trimmed as early as possible up to the height it is intended the future head should be, that cutting off of large limbs may not in future be necessary. This should be avoided when possible, as decay is liable to commence at the point of separation and extend into the trunk. When such removal is absolutely necessary, the wound should be carefully rared smooth, and a coat of paint and grafting wax applied to protect it from the action of the weather.

For the first two or three years after planting, fully one-half the growth of the previous year should be removed by heading in or reducing the length of each limb. The top limbs require to be cut back more, the lower limbs less, thus producing a more equal distribution of sap, and consequent vigor to the lower limbs. After the tree has passed, say to the third or fourth year after planting, the requirement of pruning is only to keep it in symmetrical shape and prevent particular limbs from taking a disproportionate srowth. Limbs so inclined should be headed back sufficiently and all superfiuous wood on the tree kept promptly removed. This promptly attended to will obviate any necessity for amputating large limbs.

\section{EVERGREEN AND OTHER ORNAMENTAL TREES}

The beauty of which depends on preserving the natural form, should be pruned very little. Hence, great pains should be taken in planting and caring for these.

\section{STAKING}

If the trees are tall or in exposed situations, they should be supported by stakes to prevent injury by the action of the wind. Staking is done in the best manner by driving two strong stakes firmly in the ground, one on each side of the tree, about a foot distant from it, and fastening the tree firmly between them with a band of straw or other soft material, so that it may be kept in an upright position, without chafing, till the roots obtain a firm hold upon the soil.

\section{CULTIVATING AND TRAINING AFTER PLANTING}

Many cultivators, after taking great trouble and expense in the selecting and planting of their trees, fail of success by neglecting that after-care and attention which is equally essential. The wants of the growing tree must be carefully foreseen, and a faithful effort made to insure health and productiveness. 
Frequent and thorough surface cultivation is essential to the best welfare of the young orchard.

\section{IRRIGATION}

Irrigate during the growing season as often as necessary to keep the trees in a thrifty, growing condition, this depending largely on the character of the soil and the frequency of the surface cultivation.

Cease irrigating early in the fall, so as to allow trees to ripen up their wood before going into winter. Winter killing is often caused by keeping the ground wet during the months of September and October.

A thorough wetting down after the growing season has passed and just before the ground freezes is successfully practiced and earnestly recommended by many of our best orchardists.

\section{SUMMER PINCHING}

Those who are impatient to see fruit upon their trees, as is often the case, particularly with regard to trees tardy in coming to bearing, may expedite the fulfillment of their wishes by employing the process of summer pinching. In the month of July pinch off the ends of the young shoots; this retards for the time the flow of sap and hastens the formation of the fruit buds.

\section{ASPARAGUS}

To prepare a bed, dig the ground deep, incorporating large quantities of decomposed manure. Plant the roots about three inches deep in rows about 18 inches apart and one foot apart in the rows.

\section{GRAPE VINES}

Grape vines require a dry, mellow and well-drained soil, deeply worked and well enriched with a warm, sunny exposure. In planting, give the roots plenty of room. Spread them out not more than six inches under the surface and settle the soil firmly under them. Soapsuds, sink-water and urine are good fertilizers. Nothing better than leaves and trimmings of vines kuried about the roots.

\section{CURRANTS AND GOOSEBERRIES}

Currants and Gooseberries need free pruning, so that new wood will have room to grow.

\section{ROSES}

Roses should be planted in a deep, rich, well-drained soil, so that the top roots are not less than two inches below the surface, and should be severely pruned every spring before the buds start, cutting back the last year's growth to three or four buds, except climbing roses, which may first be allowed to partly cover the space desired. Old, decayed branches should never remain. Every autumn compost should be placed around the stems of the plants and spaded into the ground in the spring. Winter covering is necessary for all tender kinds.

For planting grapes, berries, currants and gooseberries, use directions given for trees.

\section{BERRIES}

Berries should have a strong soil and be kept under constant cultivation. Faspberries and blackberries should have the old wood cut out each year and new canes pinched off when three feet high. Strawberries should be nıulched late in the fall; uncover the crowns early in the spring; remove 
mulch after fruiting and spade in a light dressing of manure. If set for fruit, keep the runners off.

Always remove straw and moss from the package before planting. Never put manure so as to come in contact with the roots of any plant or tree. Use only good soil on and around the roots.

The foregoing has been prepared with great care and with a special desire to aid our customers in the growth and care of their stock.

\section{DISTANCES FOR PLANTING}

We advise planting orchard trees close together, with a view to removing a part of them when they are large enough to crowd, thus in an orchard planted 20 feet apart by the square method, when the tops begin to crowd, every other row may be removed leaving the trees $20 \times 40$ feet; or if planted 15 feet apart every other row may be removed and every other tree in each row, leaving the fully developed trees $30 \times 30$ feet. This removal of half or three-fourths of the trees originally planted will not be necessary until after the trees have been in bearing from 6 to 10 years, or longer, and the cost and trouble of caring for an orchard with 200 trees on each acre is but little greater than where the orchard has only half or quarter that number of trees per acre, while the yield in fruit is in direct ratio to the number of thrifty bearing trees.

Standiard Apples 15 to 30 feet apart each way Standard Pears and strong-growing Cherries......10 to 20 feet apart each way Ioke and Morello Cherries.....................................10 to 18 feet apart each way Standard Plums, Peaches, Apricots, Nectarines..10 to 16 feet apart each way Dwarf Pears

Dwarf Apples 8 to 10 feet apart each way Quinces 8 to 10 feet apart each way Grapes 8 to 10 feet apart each way

Currants and Gooseberries

Raspberries and Blackberries feet in rows

Strawberries for field culture to 4 by 5 to 7 feet

Strawberries for garden culture $\ldots 1$ by 3 to $3 \frac{1}{2}$ feet .1 to 2 feet apart

\section{NUMBER OF TREES OR PLANTS ON AN ACRE}

$\begin{array}{ccccccc} & & & & & \text { Hexagonal or } \\ \text { Equilateral }\end{array}$

RULE-Square Method.-Multiply the distance in feet between the rows by the distance the plants are apart in the rows, and the product will be 
the number of square feet for each plant or hill, which, divided into the number of feet in an acre $(43,560)$, will give the number of plants or trees to the acre.

RULE-Equilateral Triangle Method.-Divide the number required to the acre "square method" by the decimal .866, or calculate the number by the "square method" and add 15 per cent. The result will be the number of plants required to the acre by this method.

\section{INSECT PEST REMEDIES

\author{
APPLE TREE APHIS \\ Quassia Chips Solution.
}

Eight pounds quassia chips; seven pounds whale-oil soap.

The quassia chips are boiled in about 1 gallon of water to each pound of chips for 5 hours. The soap is added while hot and allowed to dissolve. This solution is then diluted with 100 gallons of water. Use with sprayer when warm.

\section{TENT CATERPILLAR}

3 pounds whale-oil soap; 3 pounds sulphur; 1 can lye; 1 gallon kerosene. The egg clusters must be sought for during the winter months, when the trees being leafless, the eye will readily detect them; after being hatched out, their nests are so conspicuous that there can be no excuse for neglecting to destroy them, and where any of these pests appeared last season, thorough search must be made for these rings of eggs (which are generally found on the small branches), collecting and destroying by pouring boiling water on them or by burning them.

The following solution, if properly applied, will destroy the young larvae: Three pounds soap (whale-oil or good home-made soap), 3 pounds sulphur, 1 can lye, boiled one hour in 4 gallons water; add 1 gallon kerosene oil, boil slowly 20 minutes, then add 25 gallons of water. Use with spray pump. Do not use copper kettle in preparing solution Nos. 1 and 2 , but use kettle made of iron or some other metal.

\section{WINTER SPRAY FOR SAN JOSE SCALE AND CURL-LEAF}

50 pounds lime; 50 pounds sulphur; 50 pounds stock salt.

This will make 150 gallons of wash. Use in fall as soon as leaves have dropped and again in early spring before the buds begin to swell. Slake 50 pounds of lime, then add the 50 pounds of sulphur; boil it over a brisk fire for one hour, then place all the salt with it in the boiler and boil for 15 minutes more, then add the necessary amount of water to make 150 gallons. This solution should be used at a temperature of at least 100 degrees. Before using, strain it. The utility of this wash depends a great deal upon the strength of the sulphur. It is, therefore, recommended that those who use this wash have a Beaumes scale for acid. When it shows about 8 degrees when cold it is of proper strength. These scales can be obtained through any druggist.

\section{FOR WOOLLY APHIS AND SAN JOSE SCALE}

100 pounds lime; 100 pounds sulphur; 15 pounds blue vitriol.

Take 100 pounds of sulphur and put into a 40-gallon kettle, add about 4 gallons of water and stir until thoroughly mixed, then add about 20 gallons of water and start your fire under the kettle. Take 100 pounds of good, fresh lime and slake it in a box, keeping the lime covered with water while it is slaking; add this slowly to the sulphur; while boiling stir all the while 
to prevent burning; boil 4 hours and finish about night. Dissolve 15 pounds blue vitriol in hot water, which pour into the compound slowly, keep boiling until smooth, then let it settle for about 15 minutes, after which pour into a barrel and see that you have 30 gallons and no more. Cover your barrel up tight until morning, then open it and, as it begins to cool; keep stirring to prevent a crust from forming. When cool no crust will form, and it will keep any length of time.

Take 1 gallon of the compound to 19 gallons of water. Use about 8 gallons of boiling water to 1 gallon of the compound, making up the difference in cold water. Never spray unless the bark on tree is dry.

\section{SUMMER SPRAY FOR SAN JOSE SCALE OR GREEDY SCALE}

2 gallons water; 1 pound sulphur; 1 pound concentrated lye; one-half gallon fish-oil; one-half gallon kerosene.

For summer spraying take 2 gallons water; put into this 1 pound of sulphur, 1 pound concentrated lye; boil for two hours, then add $1 / 2$-gallon fish-oil, boil until it makes a hard soap; add $1 / 2$-gallon kerosene oil, stir well and boil a few minutes. Add to this 25 gallons cold water. For winter spraying double all the ingredients for the amount of water used. About 1 pound of whale-oil soap can be substituted for the fish-oil.

\section{CURRANT AND GOOSEBERRY SLUG OR WORM}

Hellebore is the best of known remedies, and a perfectly effectual one. Properly applied, no harm can possibly result from it. It should, according to Professor Lintner, be used in the following manner: Early in the spring, as soon as the leaves of the currant have fully put forth, watch for the first indications of the hatching and commencement of the young larvae. You have only to look for these on the lowest leaves of the bushes near the ground. The indications will be numerous small holes eaten into the leaves. Sprinkle powdered helebore over these leaves, renewing it if washed away by rain, and the desired end is accomplished. If the hellebore remains upon the leaves during the time that larvae are hatching, all will be killed and none will remain for subsequent spreading over the leaves and for the need of future atterition. If the first brood of worms is thus destroyed, there will be few, if any, to form a second brood in June.

\section{OYSTER-SHELL BARK LOUSE}

Use the same solution as for San Jose Scale heretofore described, at intervals of 10 to 15 days from May 10 to June 10 . The same solution for winter.

\section{FOR POWDERY MILDEW OR OTHER FUNGOUS DISEASES}

Bordeaux Mixture.-6 pounds copper sulphate; 6 pounds fresh lime; 45 gallons water.

Dissolve the copper sulphate into a wooden or earthen vessel, using 4 or 5 gallons of water, which, if hot, will act quicker. In a separate vessel slake the lime and rub until all lumps are broken. Then stir and strain into the copper solution. Dilute and use as soon as possible. The mixture should not stand over 20 hours, as it tends to spoil. Where a good quality of lime is used, 4 pounds will satisfy 6 pounds of bluestone, but it is best to use plenty of lime, as any free sulphate will burn the foliage. Four ounces of Paris green may be added to each 45 gallons of this liquid for all except the peach and other stoned fruits. For these use only 2 ounces. This makes the best and safest combined insecticide and fungicide for general use. 


\section{FOR CODLING MOTHS, CATERPILLARS AND SLUGS}

First application, 2 pounds line, 40 gallons water; later applications, 4 ounces Paris green, 1 pound lime, 50 gallons water.

Slake the lime; make a paste of the Paris green, mix thoroughly and then add water to make the required amount; stir thoroughly while using, and should be thrown on the leaves and fruit in a fine spray. Or use arsenate of soda spray when fruit has attained size of a hazlenut.

\section{PEAR AND CHERRY TREE SLUGS}

The Oregon Bulletin recommends the following remedy: London purple or Paris green mixed with water in the proportion of 1 ounce to 6 gallons, and apply to the foliage with a syringe or spray pump, as promptly destroying this slug.

\section{WOOLLY APHIS}

Kerosene Emulsion (Government Formula)-2 gallons kerosene; 1 gallon water; one-half pound hard soap.

Make a suds of the soap and water and pour boiling hot into the kerosene; churn with a force pump or a syringe, pumping into a bucket or barrel through a nozzle until completely emulsified. If the mixture is sufficiently hot, it will thicken in 5 to 10 minutes, and will be, when cold, of the consistency of butter or soft soap. Dilute with 7 to 12 parts of water to one of emulsion, as occasion requires, and this will kill almost anything in the form of plant lice. Be careful in using not to burn the foliage.

\section{ARSENATE OF SODA SPRAY}

2 pounds of commercial white arsenic; 4 pounds carbonate of soda,

2 gallons of water.

Use $1 \frac{1}{2}$ pints to 50 gallons Bordeaux mixture. Dissolve 2 pounds of commercial white arsenic and 4 pounds of carbonate of soda (washing soda) in 2 gallons of water, and use $1 \frac{1}{2}$ pints to 50 gallons Bordeaux mixture. The easiest way to make the solution is to put both the arsenic and soda in a gallon of boiling water and keep boiling about 15 minutes, or until a clear liquid is formed, then dilute to 2 gallons. If used without Bordeaux mixture or lime, it is liable to burn the foliage. 


\section{MISSOULA NURSERY COMPANY

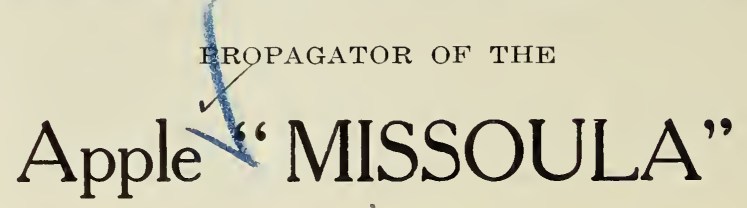

Winner of Medal at the St. Louis World's Fair, 1904, Portland Fair, 1905, and Numerous First Premiums at Local Fairs.

The original tree, as grown by C. E. Hollingsworth in Missoula, laden every year, with beautiful red apples, are the attraction of every one who passes by. The trees are about twenty years old, well branched and balanced; are iron clad in hardiness; in fact, the hardiest of any apple grown. The apples arc gems of beauty of super red color, large, round in shape; the llesh white, crisp, tender and aromatic; flavor sub-acid; in fact, excellent. As a table or market variety it far surpasses the McIntosh Red. Easily keeps until April 1st. This apple is exclusively propagated by us in Montana.

Price-Same as other apples. See page 14.

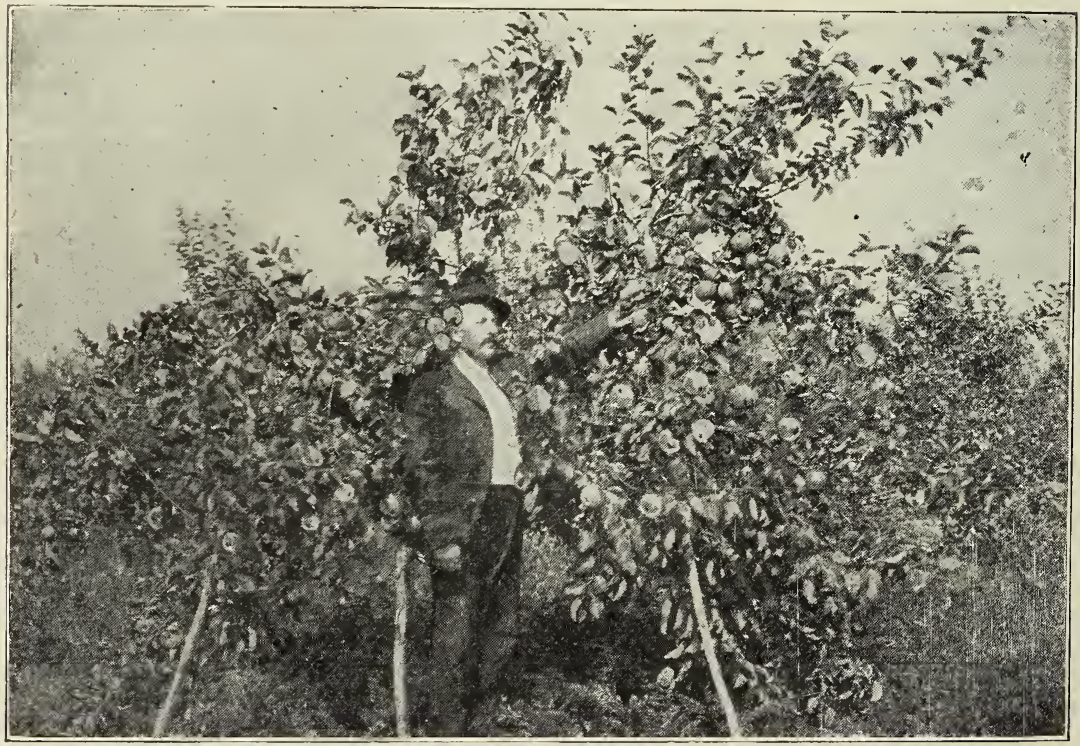

"MISSOULA" APPLE TREE FIVE YEARS OLD 


\section{TESTIMONIALS}

\section{The Following Testimonials, from a few of our leading Growers and Horti- culturists, speak for themselves:}

The Montana Agricultural Experiment Station, Bozeman, Mont., March 21, 1903.

C. F. Dallman, Mgr. Missoula Nursery Co., Missoula, Mont.

Dear Sir-This Station is in receipt of a specimen of your new apple, "Missoula." While I do not pretend to be a judge of the different varieties of apples I may say that I was struck by the fine appearance of this particular specimen. Its red color, good quality, size and shape, as well as its small core will undoubtedly place it in the front rank.

We would very much like to have a few trees of this variety to compare with numerous other hardy varieties of apple trees which are now growing in the Station orchard.

Yours truly,

S. FORTIER, Director.

Stevensville, Montana, February 27, 1903.

The Missoula Nursery Co., Missoula:-

Gents-My attention has been called to an apple called the Missoula, which is on exhibition at the Montana Horticultural Society's 7 th annuai meeting. Judging simply by the appearance and quality of the fruit, it promises to be a great acquisition to the fruit growers of the state, as it is of the very finest in appearance, of beautiful color, good size and fine in aroma and quality. W. B. HARLAN, Pres. Mont. Hort. Society.

Missoula Nursery Co., Missoula, Mont.

Missoula, Montana, March 10, 1903.

Gentlemen:-I have examined and tested your new apple, "Missoula," on exhibition at the recent meeting of the Montana Horticultural Society at Stevensville. It attracts a great deal of attention by its beautiful appearance. It certainly was the most beautiful in appearance and best in quality of any on exhibition. Its size and color make it a desirable market and fancy variety. This and the Duke of Wellington, your other seedling, would make two great market apples for Montana.

J. O. READ.

Stevensville, Montana, February 27, 1903.

Missoula Nursery Co., Missoula, Mont.

Gentlemen-I have very much admired your new apple, "Missoula," now on exlibition at the meeting of the State Horticultural Society. Its colora bright crimson red-attracts the eye, and of such size that would command a ready market, and believe it to be well worthy of consideration by the apple tree planter. Yours truly,

W. M. WOOLDRIDGE,

Industrial Agent Great Northern Railway.

Bozeman, Mont., March 16, 1903.

The Missoula Nursery Co., Missoula, Mont.

Gentlemen-The "Missoula" apples which you had on exhibition at the 
State Horticultural meeting, were surely very fine specimens. The flavor, aroma and general eating or market qualities are hard to surpass.

Yours truly, R. W. FISHER, Horticultural Experiment Station.

Missoula Nursery Co.

Stevensville, Montana, February 28, 1903.

Gentlemen-I have examined display of the apple called Missoula, at meeting of the Horticultural Society. I find it extraordinarily fine in color, in size large, and in flavor hardly equalled. From the fruit and what I am told of the history of the tree, I take pleasure in recommending it for planting in this state.

E. N. BRANDEGEE.

Butte, Montana, February 26, 1903.

Missoula Nursery Co., Missoula, Mont.

Gentlemen-I have examined with much pleasure your new apple, "Missoula," and pronounce it the most attractive apple on exhibition at this meeting. Its size and color could not be improved upon, and it seems to be a fairly good keeper; and believe it worthy of trial and consideration by those interested in growing apples.

Yours truly,

I fully endorse the above in every particular.

ROBT. B. SMITH.

C. M. ALLEN, Mem. State Board of Hort., 4th Dist.

Butte, Montana, February 27, 1903.

Missoula Nursery Co., Missoula, Mont.

Gentlemen-I have examined the new apple "Missoula," on exhibition at Buck's hall. It is a beautiful apple, luscious, firm and fine appearing. It should make a splendid seller, as it appeals both to the sight and taste. I predict for it a great future. Respectfully yours,

J. R. WHARTON.

Missoula, Montana, March 4, 1903.

Missoula Nursery Company, Missoula, Montana.

Gentlemen-I saw your new apple, "Missoula," exhibited at Stevensville and I am free to confess that it was the most beautiful and appetizing apple I ever saw.

Very respectfully, ELMER E. HERSHEY.

The Montana Agricultural Experiment Station. Bozeman, Montana, March 5, 1903.

Missoula Nursery Co.

C. F. Dallman, Manager, Missoula, Mont.

Dear Sir-I duly received the specimen of the new apple, "Missoula," which you sent by express. I am much pleased with its appearance and flavor. Its color and size are first class and the flavor is excellent. It certainly is an apple to attract the eye of the consumer and merchant, and nothing could be more beautiful than a tree loaded with these apples. I congratulate you on possessing it, and I trust that it may soon find its way into our list of commercial apples. I am very truly yours,

R. A. COOLEY, Entomologist. 
Butte, Montana, March 23, 1903.

Gentlemen-Replying to your favor inquiring what $I$ think of the "Missoula," the new apple propagated by you, will say I think it a splendid apple. In color and size it is superior to anything we are now growing; its quality excellent and will make a leader in any market. Truly yours,

C. H. EDWARDS, Secy. State Board Hort.

Missoula Nursery Co.

Missoula, Montana, March 24, 1903.

Gentlemen-I want to congratulate you on the stir your new apple, "Missoula," is making in the horticultural world. Having examined, studied and pruned the original trees of Missoula for several years, I believe it to be an iron clad and adapted to trying localities equal to Wealthy and Alexander. In productiveness, size, color, beauty and quality, it is certainly the

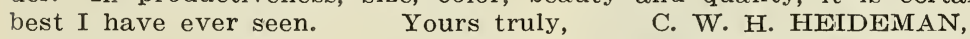

Secretary State Horticultural Society.

From the Stevensville Register, Feb. 25, 1903:

The seventh annual meeting of the Montana Horticultural Society began its sessions here today, and will conclude with a grand banquet at the Hotel Stevensville Friday evening. The exhibits of the Missoula Nursery Company are attracting much attention. The pressed specimens of foliage were gathered in the company's orchard, and will be placed on exhibit at the Columbia Gardens in Butte. In the company's fruit exhibit are a few samples of the Missoula apple, which originated in the Montana city of that name. Many have remarked upon its beauty; it is of large size, will easily keep until March and is said to be of an exceptionally fine flavor.

The Lothrop Land and Stock Company. Lothrop, Montana, April 22, 1912.

Missoula Nursery Company, Missoula, Mont.

Gentlemen: Trees ordered by Mr. Lusk arrived in good shape and are all set out. Thanking you kindly for pointers asked, I am, yours truly,

LOTHROP LAND \& STOCK CO.,

By R. P. MсCOMB.

Carlton, Montana, April 15, 1912.

Missoula Nursery Company, Missoula, Mont.

Gentlemen: I enclose check for thirty-one (\$31.00) dollars in payment for trees. They came in good condition. GEO. F. RIGBY.

\section{We have hundreds of other testimonials on file in our office,} many of them no doubt from your neighbors. Ask us for them. 


\section{APPLES}

The first fruit in importance is the apple. Its period of ripening, unlike that of other fruits, extends nearly or quite through the year. By making judicious selections of summer, autumn or winter sorts, a constant succession can be easily obtained of this indispensable fruit for family or market use.
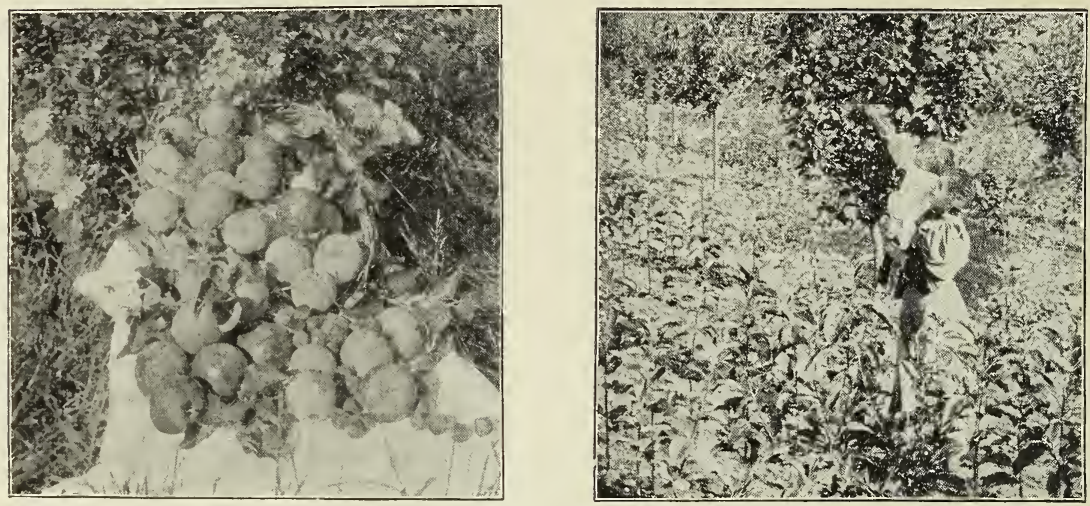

There is no farm crop which, on an average, will produce one-fourth as much income per acre as will a good apple orchard. The average prices paid for the fruit is steadily on the increase, and the immense demand for home consumption, foreign shipping, canning and evaporating, assures us that they will continue to increase.

\section{APPLES}

Extra large, special selected, each $\$ 1.00$ and up.

\begin{tabular}{|c|c|c|c|c|}
\hline & & Per & Per & Per \\
\hline & Each & 10 & 100 & 1000 \\
\hline Standard, 5 to & $\$ .50$ & $\$ 4.00$ & $\$ 35.00$ & $\$ 300.00$ \\
\hline Standard, 4 to $5 \mathrm{ft}$. & .......... $\quad .40$ & 3.50 & 30.00 & 250.00 \\
\hline Standard, 3 to $4 \mathrm{ft}$. & 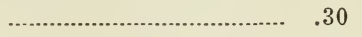 & 2.50 & 20.00 & 150.00 \\
\hline Sitandard, 2 to $3 \mathrm{ft}$. & (1) & 2.00 & 15.00 & 100.00 \\
\hline Standard, 1 to $2 \mathrm{ft}$. & . & 1.50 & 10.00 & 50.00 \\
\hline
\end{tabular}

\section{SUMMER APPLES.}

Astrachan, Red-Large, roundish; nearly covered with deep crimson, overspread with a thick bloom; juicy, rich, acid, beautiful. The tree is a vigorous grower, with large foliage and a good bearer. August.

Carolina Red June-Medium size, red, flesh white. Last of June.

Yellow Transparent-A new Russian variety imported in 1870 , through the Agricultural Department. Pronounced by some who have seen it as "the most valuable early apple ever introduced." Tree an upright grower and a very early and abundant bearer. Fruit of good size; skin clear white, turning to a pale yellow; flavor acid and very good. Ripens from ten days to two weeks earlier than Early Harvest. 


\section{AUTUMN APPLES}

Autumn Strawberry-Tender, juicy, productive.

Duchess of Oldenburg-Of Russian origin. Large size, roundish; streaked with red and yellow; flesh whitish, juicy; flavor sprightly; sub-acid; tree a vigorous grower, very hardy; very early and abundant bearer. While it is indispensable in the North it is almost equally so in the South. We confidently recommend it for the orchard as one of the most valuable sorts for market, or in the garden for domestic use. September.

Gravenstein-Large, striped and beautiful; tender, juicy and high flavored; vigorous and productive; very good. September and October.

Maiden's Blush-Medium size, flat, quite smooth and fair; pale yellow, with beautiful red cheek; tender, sprightly, pleasant acid flavor. Fair grower and good bearer. September and October.

Red Betigheimer-A rare German variety, very recently introduced. Fruit large to very large; skin pale green color, mostly covered with purplishcrimson; flesh, white, firm, sub-acid, with a brisk, pleasant flavor. Tree a fine grower and abundant bearer. This is one of the largest and handsomest of apples, and promises to be extensively cultivated. September and October.

\section{EARLY WINTER}

Alexander-(Emperor)-of Russian origin. Large; deep red or crimson; flesh yellowish-white, crisp, tender, with pleasant flavor. Very hardy. October.

Bismarck-Tree of short stock growth, thick, healthy foliage; makes beautiful specimens grown in pots for decorative purposes. Fruit large, handsome, yellow, sometimes shaded red cheek; flesh tender, pleasant subacid, entirely new in its remarkable quality of producing crops on young trees, seldom failing to bear when two years old.

Fameuse-(Snow Apple)-Medium size; round, oblate whitish ground, striped with deep red; flesh very white, juicy and pleasant. Tree very hardy; one of the most valuable Northern sorts. November and December.

McINTOSH RED-See description on back cover.

Peter-Resembles Wealthy in size and color, four to six weeks later. Perfectly hardy.

Wealthy-A seedling originated by Peter M. Gideon, at Lake Minnetonka, Minn. A fine nursery tree, very hardy, an early and abundant bearer; fruit large, dark crimson in color; flesh crisp, sub-acid, white, tinged with red; quality second to none. This tree is deservedly making a first-class record wherever planted. November to February. Late winter.

Winter Banana-Fine, vigorous grower, large, healthy foliage, early bearer. Fruit medium to large, smooth and handsome, golden yellow, usually shaded bright crimson; flesh fine grained, rich, sub-acid, aromatic, highest quality. One of the best dessert apples; easily grown, a good shipper.

Wolf River-Large, handsome; yellow shaded and striped red, juicy, pleasant spicy flavor.

\section{LATE WINTER}

Baldwin-Large, bright red, crisp, juicy, rich. 
Belleflower, Yellow-Large, yellow, with blush cheek; very tender, juicy sub-acid. In use all winter. Very valuable. A moderate grower and good bearer.

Blue Pearmain-Tree hardy. Fruit large, dark red, rich; sub-acid. December to February.

Grimes' Golden-(Grimes' Golden Pippin)-An apple of the highest quality; medium to large size; yellow, tree hardy, vigorous, productive. January to April.

Jonathan-Fruit medium or small, roundish; skin yellow, nearly covered with dark or lively red; fine grained, very tender and finely flavored; tree slender and spreading, with light colored shoots. November to April.

Gano-A large, handsome, striped apple of good quality; tree very hardy, vigorous and productive; a late keeper. Highly esteemed in the West and Southwest.

Delicious-One of the best of the good sorts, large, somewhat conical, color a brilliant red, shading to golden yellow at the tip; flesh white, sweet and slightly acid, very fragrant, fine grained and crisp; a good keeper. Tree is strong, vigorous and very productive; a high grade commercial apple.

King of Tompkins Co.-Large to very large, handsome; yellow and red; good quality. Will keep the year around.

Lawver-(Delaware Red Winter)-Large, roundish flat; mild, sub-acid, very heavy and hard; beautiful dark red; handsomest of all the extra late keepers; very valuable as a late market sort; tree a vigorous grower and very hardy; bears well; very promising late market variety. December to May.

Nonpareil-Large, handsome, yellow shaded and striped red; juicy, pleasant, spicy flavor.

Northwestern Greening-Hardy, yellow; rich, of good size, extra long keeper.

Northern Spy-Large, roundish, slightly conical, somewhat ribbed; striped with the sunny side nearly covered with purplish red; flesh white and tender, with a mild sub-acid, rich and delicious flavor; in perfection in January and keeps till June; tree is a strong, upright grower, and forms a very compact head; should be kept open by pruning, so as to admit the air and light freely.

McMahon White-Yellowish white, often with a delicate pink blush; large, handsome tree and strong, healthy grower; abundant bearer.

Pewaukee-Medium size, bright yellow, splashed red; sub-acid, with rich, aromatic flavor.

Red Napoleon-Large, dark red; hardy and productive; vigorous grower.

Rome Beauty-Large; yellow, shaded with bright red; flesh yellowish, tender, juicy, sub-acid; moderate grower. November to February.

Rhode Island Greening-Large; greenish-yellow; tender, juicy and rich with rather an acid flavor; growing strong and spreading, and an abundant bearer. December to April.

Russet Golden-Medium size; dull russet, with a tinge of red on exposed side; flesh generally crisp, juicy and high-flavored; tree a vigorous grower and a great bearer; very popular. November to April.

Russet, Roxbury or Boston-Medium to large; greenish or yellow russet; crisp, good sub-acid flavor; tree vigorous and productive; very popular on account of its long keeping. June. 
Spitzenburg-Fruit medium, roundish; skin yellow, nearly covered with dark or lively red; moderate grower. One of the best apples for home use or market. October to March.

Sweet Romanite-Medium; pale yellow, slightly tinged with red; firm, rich and very sweet; valuable baking apple; vigorous and productive. November to April.

Tallman's Sweeting-Medium; pale yellow, slightly tinged with red; firm, rich and very sweet; the most valuable baking apple; vigorous and productive. November to April.

Wagoner-Large, shaded bright red on pale yellow; crisp, tender, mild, subacid.

Walbridge-Medium size; striped with red; handsome and of excellent quality; vigorous grower and productive; very hardy and considered of great value in the North and Northwest. March to June.

White Winter Pearmain-Above medium size, roundish, oblong, conic; pale yellow, with a slight blush; extra high flavor; one of the best. December to March.

Winesap-Medium, dark red; a favorite market variety in the West. November to April.

Winter Maiden Blush-Hardy, fine, thrifty grower, healthy foliage, bears young; very productive. Handsome fruit, good size, yellow, usually with blush cheek; mild, sub-acid, rich, aromatic, spicy flavor; keeps and ships well.

York Imperial-This apple has been gaining in favor, and is being planted largely in the West as a commercial sort. Large.

Yellow Newtown Pippin-This stands as high as any apple in our markets, and is one of the best keepers; flesh firm, crisp, juicy and with a fine flavor. January to June.

\section{CRAB APPLES}

\section{(Prices the Same as Apples)}

Within the past few years much attention has been given to improving this class of fruit because of its adaptability to cold sections where only a few varieties of apples can be successfully grown. These efforts have been attended with marked success. Crab apples succeed remarkably well in all sections and are valuable for preserving, jelly, ornament, and some of the improved sorts are excellent for eating. Sent to the eastern markets they command a very high price.

General Grant-Tree an erect, vigorous grower; fruit in dense clusters; quality equal to Duchess of Oldenburg. October to December.

Hyslop-Almost as large as Early Strawberry Apple; deep crimson; very popular on account of its large size, beauty and hardiness. Keeps well into the winter.

Martha Crab-A new fruit raised from seed of the Duchess of Oldenburg. Resembles the 'Transcendent, but larger. Handsome, showy fruit; bears enormously; said to be equal, if not superior, to all others for sauce.

Transcendent-All things considered, this is one of the most valuable varieties of crab apple grown. Tree remarkably vigorous, growing to a good size and immensely productive. Comes into bearing a little the second 
year from planting and bearing every year after, and producing good crops by the fourth year. Fruit very large, from one and one-half to two inches in diameter, being large enough to quarter and core for preserving and drying. Excellent for sauce and pies, both green and dried. The best of its class for cider, being juicy and crisp, and is also by many considered a good eating apple. Skin yellow, striped with red. September and October.

Whitney No. 20 Seedling-Large, averaging one and a half to two inches in diameter; skin smooth, glossy green, striped, splashed with carmine; flesh firm, juicy and rich. Said to be a great bearer and very hardy. Tree a vigorous and handsome grower. Has no superior.

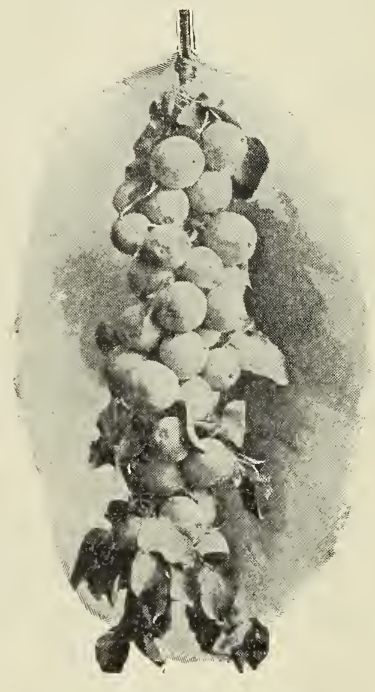

TESTIMONIALS.

Victor, Montana, May 6, 1912.

Missoula Nursery Company.

Sirs: The trees (H. Crabs) received and a finer bunch could hardly ever be found. You will find herein check (\$3.75) for same.

Yours Very Respectfully, JONAS JOHNSON.

Butte, Montana, April 25, 1912.

Missoula Nursery Co., Missoula, Mont.

Sirs: I received my order for trees today (order No. 439) through the Butte Chamber of Commerce, and am well pleased with them. Will probably order more next season. Please tell me by return mail if the trees should be pruned now. Also tell me name of bush and plant that came with trees. Yours respt.

C. T. CAMPBELL, 1055 W. Gold Street.

Missoula Nursery Co., Missoula, Mont.

Forsyth, Montana, August 21, 1911.

Gentlemen: Enclosed is two crabapples. Will you kindly tell me what kind of a crab they are. I got these trees of you some six years ago and 
will want more in the spring. They do extra fine here. Thanking you, I am yours very truly,

L. L. CROCKETT.

Office of Railroad Commissioners.

Mr. C. F. Dallman, Missoula, Mont.

Helena, Montana, October 31, 1911.

Dear Sir: I am enclosing two snapshot pictures taken of the orchard set out this spring near Helena. These trees were received from you and set out March 22, 1911. They were not irrigated; cultivated two or three times during the months of May, June and July. Every tree received is alive today. On many of the Transcendant trees, the limbs grew from 40 to 48 inches long. They are the finest bunch of trees $I$ have seen in any part of the state. With kind regards, I am, yours very truly,

DANIEL BOYLE.

Mr. C. F. Dallman, Proprietor, Missoula, Mont.

Butte, Montana, May 14, 1912.

Dear Sir: Enclosed please find check for $\$ 4.00$ for trees which I received last Saturday and for which I thank you very, very much. I appreciate the attention given the order and am very much pleased with the trees. If you have any kind of vines for sale I would like to have some, so if you will advise me in regard to them $I$ would be very thankful. Thanking you for your kindness, I am Yours truly,

M. A. MURPHY,

111 E. Workman Street, Butte, Mont.

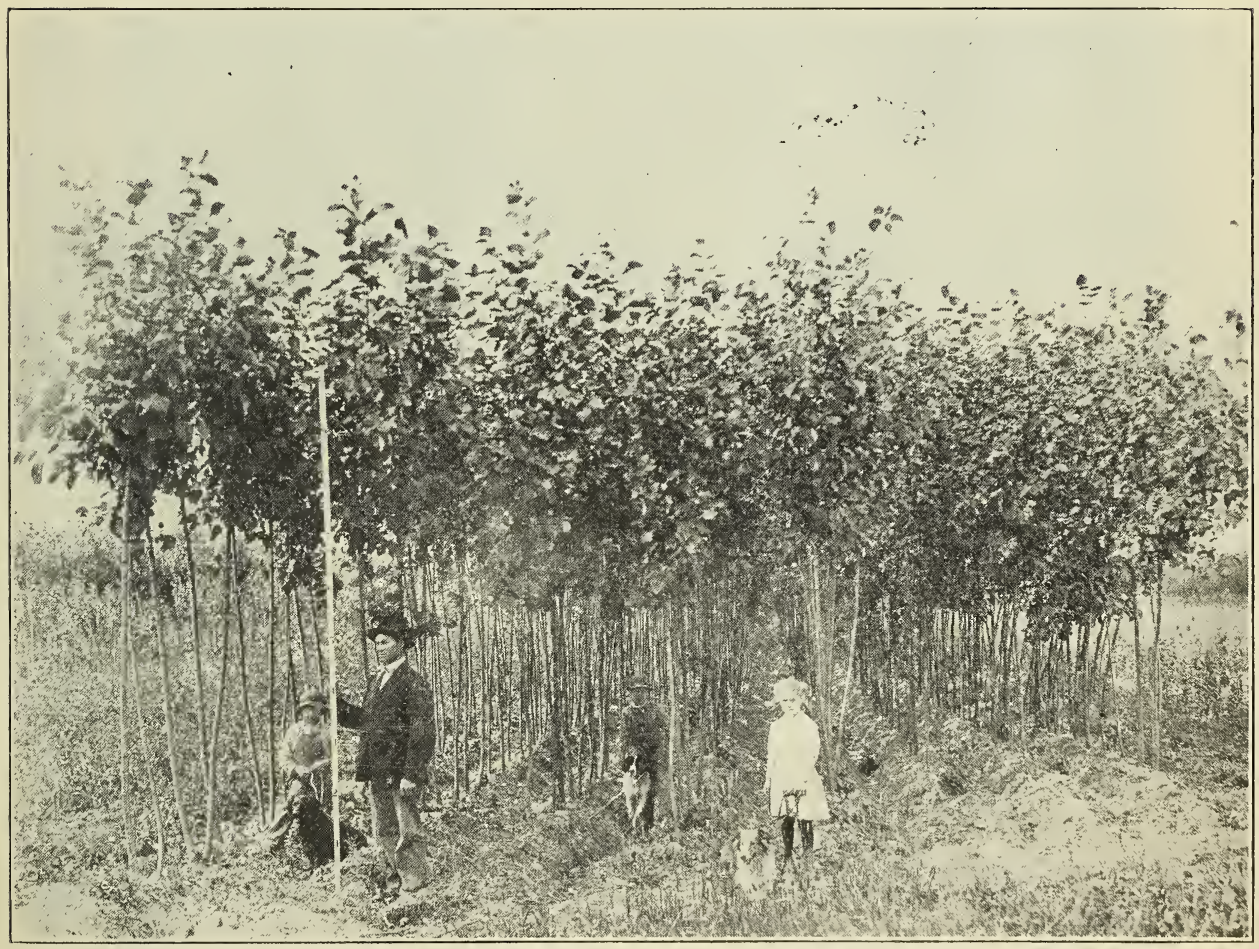

VIGOROUS STOCK AND CLEAN. 


\section{PEARS}

The cultivation of this noble fruit is rapidly extending as its value is appreciated. The range of varieties is such that, like apples, they can be had in good eating condition from August until winter.

The melting, juicy texture, the refined flavor and the delicate aroma of the Pear, give it rank above all other fruits, except the Grape. The Pear, like most things highly desirable and valuable, cannot be had without attention and labor. The relative prices of the Apple and Pear being about as one to five, purchasers of the latter can well afford to give the trees the high cultivation necessary to secure the best results.

Extra Large' Special Selected, each, $\$ 1.00$ and up.

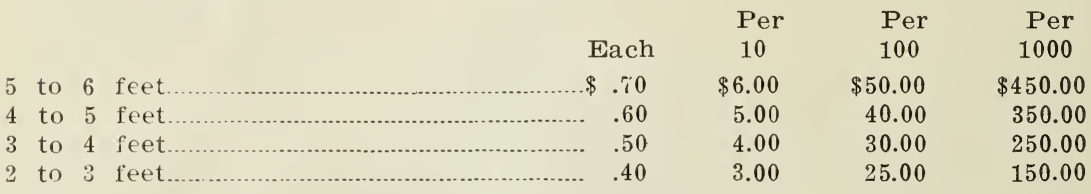

Anjou-A large greenish Pear, shaded with russet-crimson; the flesh is high flavored, rich, and vinous; the tree is very productive either as dwarf or standard. For late fall and very early winter use we have no better variety. Keeps well until winter holidays, when it demands a high market price.

\section{SUMMER}

Bartlett-Large size, often with a blush next the sun; buttery, very juicy and high flavored. Tree a strong grower; bearing early and abundantly; very popular. Last of August and first of September.

Clapp's Favorite-A large, new, fine Pear, resembling the Bartlett, but without its musky flavor; pale, lemon yellow, with brown dots, fine texture, melting, buttery, juicy, with a rich, sweet, delicate, vinous flavor. Tree hardy and very productive; very desirable in all sections, and especially so where other varieties fail. August and September.

Comice-(Duc De Comice)-Fine, yellow, faint crimson blush, aromatic; long keeper. It begins to look as if there is to be no end of the possibilities of the Comice Pear in Montana. Returns from a mixed car of Comice and other varieties consigned to a New York firm show 589 half boxes of Comice which sold readily at public auction at $\$ 4.00$ per half box, or $\$ 8.00$ per box straight, a price far beyond anything ever before realized for pears.

\section{AUTUMN}

Flemish Beauty-Large, nearly covered with reddish brown where exposed to the sun. The fruit should be gathered sooner than most Pears, even before it parts readily from the tree. If it is then ripened indoors it is always fine. September.

Keifer's Hybrid-A cross between the Chinese Sand Pear and the Bartlett. Commences bearing very young and produces regular and abundant crops of fruit; large, russety; flesh white, buttery and juicy. Quality good. October.

Seckle-One of the best pears; small, but of the highest flavor, melting and juicy. Always in demand as a dessert and market pear. Ripens September to October. A good pear for the West. 


\section{CHERRIES}

\section{For Garden and Market.}

There are few trees more attractive than the Cherry, on account of its beautiful foliage, attractive blossoms and showy fruit. It is often planted upon the lawn of the village and city as well as upon the farm lawn. It furnishes a delightful shade and is a clean tree.

Extra Large, Special Selected, each $\$ 1.00$ and up.

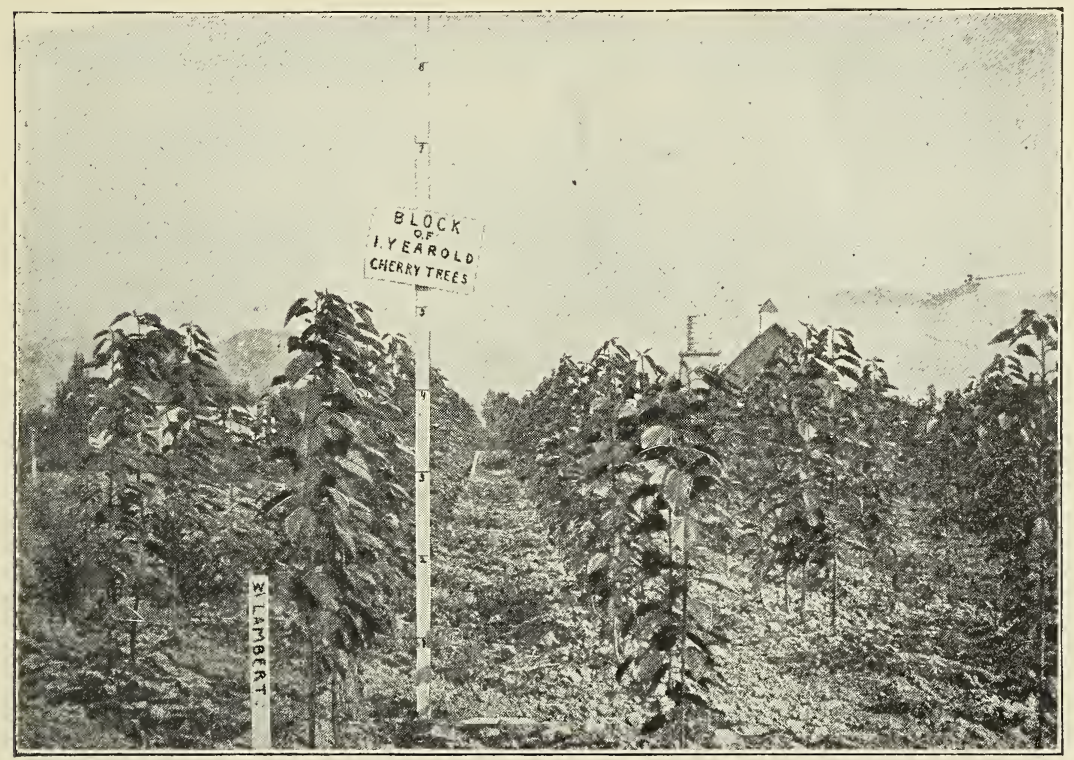

ONE-YEAR-OLD LAMBERT TREES.

SWEET CHERRIES

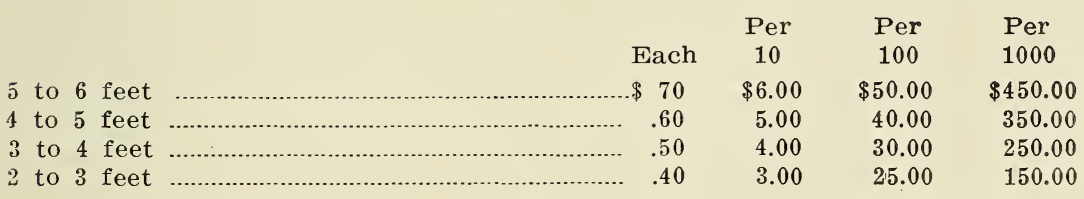

Bing-This deservedly popular cherry originated by Seth Lewelling, of Milwaukee, Oregon, is one of the grandest black cherries in existence today. Its large size, firmness and delicious flavor have caused it to be in active demand by shippers and canners alike. The tree is a remarkably thrifty upright grower and a prolific bearer.

Black Tartarian-Very large; bright, purplish black; half-tender, juicy, very rich, excellent flavor. Tree a vigorous grower and productive.

Black Republican-Extremely large, very black, juicy, sweet, luscious, good and constant bearer; one of the best shippers; late. 
Governor Wood-Very large, rich; light yellow with red cheek; juicy and very sweet; one of the very best.

Lambert-Black, one-half larger than Luelling, Black Republican. Flesh very solid; flavor of the highest quality. Tree thrifty, upright grower, very hardy and productive. A fine shipping and market variety.

Royal Ann-Very large, amber spotted with deep red; very firm, juicy and sweet; good and constant bearer.

\section{SOUR CHERRIES}

English Morello-Without doubt one of the most valuable of this class. Easily grown, generally producing a heavy crop. Fruit dark red, quality good, with a rich, acid flavor; late. Tree very hardy and recommended for extreme cold latitudes.

Early Richmond-An early, red, magnificent Cherry; very valuable for cooking; season early.

Montmorency-Large; bright, shining red; acid; late; valuable. Larger than Early Richmond. Hardy and productive. This variety seems to be almost as popular as the Early Richmond. We seldom have trees enough to supply the demand.

May Duke-Large, red; juicy and rich; an old favorite and very productive.

Wragg-Originated in Iowa and has become very popular in the Northwest and Western states. Fruit, medium to large, dark red and of fine quality. Tree is very hardy, vigorous and productive. This is one of the few cherries of good commercial quality that is perfectly hardy. Ripens in July.

Ostheimer-A perfectly hardy, late blooming, immensely productive variety. Large, heart shaped, nearly black when ripe; juicy and rich. August.

\section{TESTIMONIALS.}

Deer Lodge, Montana, May 8, 1912.

Missoula Nursery Co., Missoula, Montana.

Gentlemen: The trees arrived in excellent condition, and are very fine considering the late date we ordered them. The cherry trees were exceptionally fine and large, and greatly pleased my father, who is taking much interest in his new orchard. I noticed your prices were quite a bit better than listed in the catalogue (no doubt due to the late date) so for that reason the orders did not amount to as much as I had expected, and now I am trying to make up the amount in more orders. The members of the Woman's Club thank you most sincerely for the lovely lot of trees and shrubs you presented to the Club House. We have a fine corner and they will show off well there. You are becoming pretty well known here as we are scolding the people who send east and get cheated by buying stock that is not at all adapted for this climate. Thanking you again for your generosity, believe me,

Sincerely yours,

ALMA M. HIGGINS.

Missoula Nursery Company.

Florence, Montana, May 4, 1912.

Gentlemen: The trees came all O. K. I am sending a P. O. order for $\$ 6.50$, as there was 10 trees dead from last year's trees. If this is not right 
I will send the other dollar. Next year I think I will give you a large order for cherry trees. I think it too late to plant them out this year.

Yours truly,

A. A. SETTLEMIER.

Missoula Nursery Company.

Great Falls, Montana, May 9, 1912.

Dear Sirs: I received the trees sometime ago. They were in fine condition and I thank you for the carnation.

Yours truly, JOSEPH HERRING.

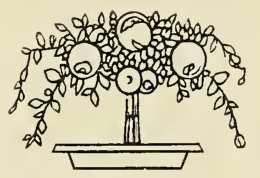

\section{OUR BEST ADVERTISEMENT}

Scattered through this book are copies of letters which we have received from those who have used our nursery stock-fruit trees, shade trees and flowers. These are but random selections from hundreds of similar letters which are on file in our office; the originals we are glad to show to anybody who is interested. Our best advertisement is found in the commendation of our stock, given by those who have used most of it. It is a source of gratification to us that we have permission to refer to any of the people who have used stock from The Missoula Nursery; the letters which are reproduced in this book have come to us entirely unsolicited. We would like you to see the originals. We have cordial indorsement of our stock from such people as Mrs. W. I. Higgins of Deer Lodge, head of the city improvement work of the Montana Federation of Woman's Clubs, who has used our shade trees and flowers under many circumstances; the Lothrop Land \& Stock Company is enthusiastic over our fruit tree stock; A. A. Settlemeir of Victor, who writes in approval; E. J. Stanley of Whitehall, whose indorsement is cordial; C. T. Campbell of Butte, who is enthusiastic; Daniel Boye, state railroad commissioner; W. MeWhite of the Butte Ice Company, who has given our shade trees a thorough trial in the severe conditions which prevail in Silver Bow county; H. A. Stewart of Hamilton; Mrs. R. A. Clark of Roland, Idaho; R. A. Barnes of the State Agricultural College. We might extend this list indefinitely had we the space. We renew our invitation to you to come and see for yourself the words of those who have tried our trees and shrubs and flowers. We are advertised by our customers. There is no stronger advertisement than that.

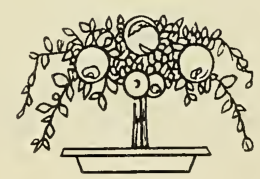




\section{PLUMS AND PRUNES}

\section{PLUMS}

The Plum delights in a cool, not too dry situation, and good, rich soil. Plant in rows north and south with trees 10 to 15 feet apart in rows, far enough from each other to give good air circulation. The varieties we offer have been thoroughly tested, and are standbys. These may be relied upon to furnish yearly crops of this most highly profitable and exceedingly delicious fruit.

The only serious difficulty is that many of the best sorts are not selffertile and though blooming abundantly, they must have the company of other varieties to enable them to mature fruit. Therefore, be sure to plant several varieties together.

Extra Large Special Selected, each, $\$ 1.00$ and up

\begin{tabular}{|c|c|c|c|c|}
\hline & Each & $\begin{array}{l}\text { Per } \\
10\end{array}$ & $\begin{array}{l}\text { Per } \\
100\end{array}$ & $\begin{array}{r}\text { Per } \\
1000\end{array}$ \\
\hline 5 to 6 feet & $\$ 70$ & $\$ 6.00$ & $\$ 50.00$ & $\$ 450.00$ \\
\hline 4 to 5 feet & .60 & 5.00 & 40.00 & 350.00 \\
\hline 3 to 4 feet & .50 & 4.00 & 30.00 & 250.00 \\
\hline 2 to 3 feet & .40 & 3.00 & 25.00 & 150.00 \\
\hline
\end{tabular}

Abundance-(Botan)-One of the oldest and best known Japanese varieties; hardy and productive. Fruit large, lemon yellow, with heavy bloom; good quality. August.

Bradshaw-A very large and fine early plum, dark violet red, juicy and good. Tree erect and vigorous; very productive; valuable for market.

Burbank-The best and most profitable among growers for market; ripens ten to fourteen days after Abundance. Tree hardy, sprawling, vigorous grower, unequalled in productiveness; bears young. Fruit large, excellent quality; cherry red with lilac bloom. August.

Columbia-Fruit of the largest size, six or seven inches in circumference, nearly globular. Skin brownish-purple, dotted with numerous fawn-colored specks. Flesh orange, not very juicy, but when at full maturity very rich, sugary and excellent. Last of August.

Damson-Fruit small, oval, skin purple, covered with blue bloom; flesh melting and juicy, rather tart, separates partly from the stone. Very good for canning. September.

Lombard-The Lombard is a great favorite for the following reasons: The tree seems to adapt itself to any locality; it is extremely hardy, producing good crops where many varieties will not even grow.

Peach Plum-Fruit very large, round, greenish white with red cheek; flesh yellow, sweet and firm; early, good for shipping. Best for Montana.

Pond's Seedling Plum-Very large, dark red, juicy and sweet. Its large size, bright color and productiveness and shipping qualities render it a profitable variety for home and distant markets. September.

Yellow Egg-Large, egg-shaped; good and productive. August.

\section{NATIVE PLUM}

Pissardi or Purple Leaved-A small sized tree with very rich purple leaves, carry their color through the season; the most desirable purple leaf tree or shrub for ornamental planting. 
The Montana-A strong, vigorous grower, hardy and an immense bearer; fruit large, yellow ground overspread with pink and white. August.

\section{PRUNES.}

German-Medium, oval; purple or blue; juicy, rich, fine. Tree moderately vigorous and very productive. One of the best. September.

Golden-A seedling of Italian prune. Light golden color, good flavor and a heavy drier, strong grower and a heavy bearer. Very free from stone. September.

Italian-Fellenberg-Medium size, oval; dark purple; flesh juicy and delicious; parts from stone. One of the best for drying.

Tennant-Large, dark purple with a blue bloom; flavor of the highest quality, rich, sugary and delicious. Tree hardy, and never fails to produce an abundant crop. August.

\section{APRICOTS}

Extra Large Special Selected, each $\$ 1.00$ and up.

\begin{tabular}{rrrrrr}
5 & & Per & \multicolumn{1}{c}{ Per } \\
4 & to 6 feet & Each & 10 & 100 \\
4 & to 5 feet
\end{tabular}

Gibb-Tree hardy, grows symmetrical, productive; fruit medium; yellowish, sub-acid, juicy and rich. The best early variety, ripening soon after strawberries. A great acquisition.

J. L. Budd-Tree a strong grower and profuse bearer; fruit large, white, with red cheek; sweet, juicy, with a sweet kernel as fine flavored as an almond. The best late variety and a decided acquisition. August.

\section{QUINCES}

Extra Large Special Selected, each $\$ 1.00$.

3 to 5 feet, 3 years old $\quad \begin{array}{ccc}\text { Per } & \text { Per } \\ 10 & 100\end{array}$

Champion-A prolific and constant bearer; fruit averaging larger than the Orange, more oval in shape, quality equally fine, and a long keeper, bears extremely young. Ripens late.

\section{PEACHES}

Extra Large Special Selected, each, $\$ 1.00$ and up.

\begin{tabular}{|c|c|c|c|c|}
\hline & & Per & Per & Per \\
\hline & Each & 10 & 50 & 100 \\
\hline 5 to 6 feet & $\ldots \$ .60$ & $\$ 5.00$ & $\$ 22.50$ & $\$ 40.00$ \\
\hline to 5 feet & $\ldots .50$ & 4.00 & 17.50 & 30.00 \\
\hline
\end{tabular}

Alexander-Medium to large; greenish white, covered with a deep rich red; very juicy, cling to stone. Best early market variety.

Early Crawford-A magnificent, large, yellow peach of good quality. Its size, beauty and productiveness makes it one of the most popular varieties. Extensively planted. Freestone. 
Late Crawford-A superb large, yellow, freestone peach; very rich. Last of September.

Triumph-Earliest yellow flesh peach; ripens a few days later than Alexander, blooms late; sure and abundant bearer; strong, vigorous grower; fruit good size; yellow, with red and crimson cheek.

\section{GRAPES}

Extra Large Special Selected, each $\$ 1.00$.

First-class plants, 2-1

Each, 25c; ten, $\$ 2.00$

Brighton-A cross between Concord and Diana Hamburg. Resembles Catawba in color, size and form of bunch and berry. Flesh, rich, sweet and of the best quality. Ripens earlier than the Delaware, vine vigorous and very hardy. This variety has now been thoroughly tested and it may now be said to be without an equal among early grapes.

Concord-A large, handsome grape, ripening two weeks before the Isabella. Very hardy and productive. Succeeds over a great extent of country, and although not of the highest quality, it is one of the most popular market grapes.

Delaware-still holds its own as one of the finest grapes. Bunches small, compact, shouldered; berries rather small, round; skin thin, light red; flesh very juicy without any hard pulp, with an exceedingly sweet, spicy and delicious flavur. Vine moderately vigorous, hardy and productive Ripens two weeks before the Isabella.

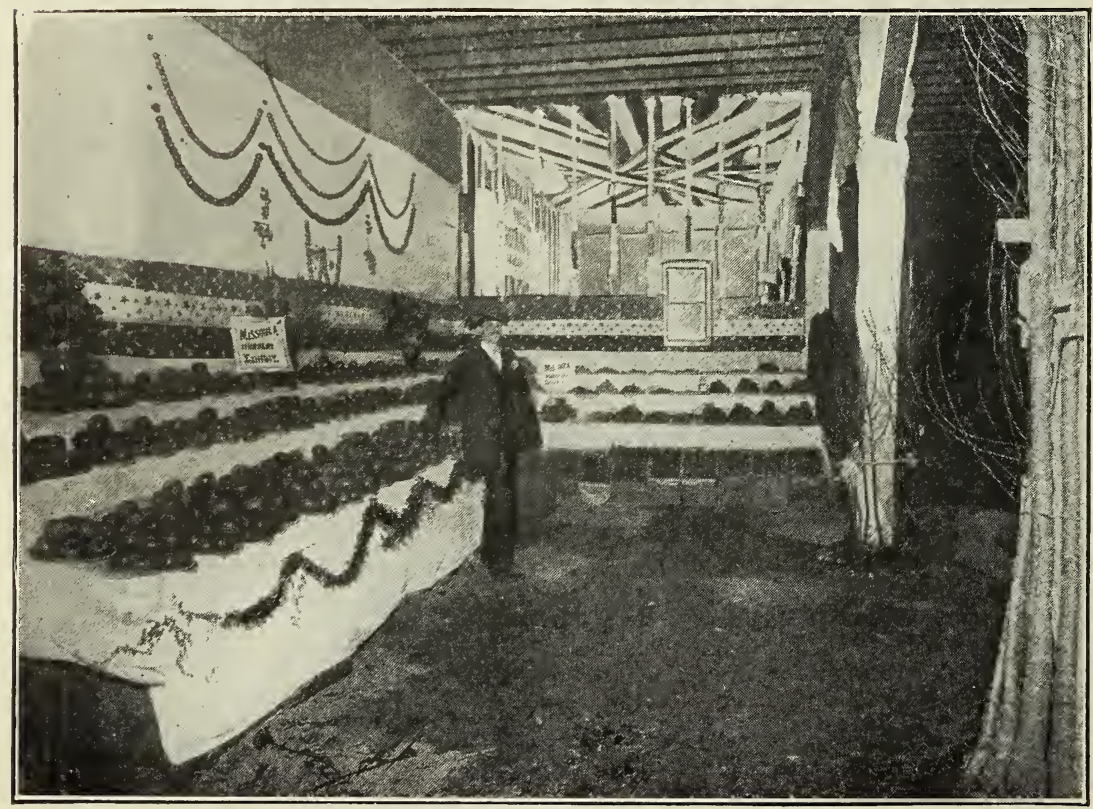


Moore's Early-A new grape raised from seed by John B. Moore, Concord, Mass., in 1872. It is described as follows: Bunch large, berry round, as large as Wilder or Rogers' No. 4, color black, with a heavy blue bloom; quality better than the Concord, vine exceedingly hardy; has never been covered in the winter and has been exposed to a temperature of more than 20 degrees below zero without injury to it; has been entirely exempt from mildew or disease. Its earliness makes it desirable for an early crop and more particularly adapts it to this country and the northern portion of the United States.

Niagara-Occupies the same position among the white varieties as Concord among the black. Very sweet. September.

Royal Muscadine-Almost identical with the Sweetwater. Berries little larger and only a few days later. Sweet, delicious.

White Sweetwater-This is the earliest grape to ripen. Vines hardy; fruit rich and sweet. First of August.

\section{CURRANT CULTURE}

What is more beautiful or more easily cared for than the currant bush? The demand for this fruit is increasing. Currants have ever been, and ever will be the housewife's favorite fruit. There is no fruit which is more healthful and easily grown. It will succeed with neglect, but will respond generously to high culture, giving double the size fruit under good treatment. The currant worm is destroyed easily with a slight early application of powdered helebore when the leaves are damp with dew and when the leaves first appear. The trouble with most planters is that they plant the bushes too close together. We would prefer rows six feet apart, with the bushes at least three feet apart, if grown in rows. If in blocks, at least four feet

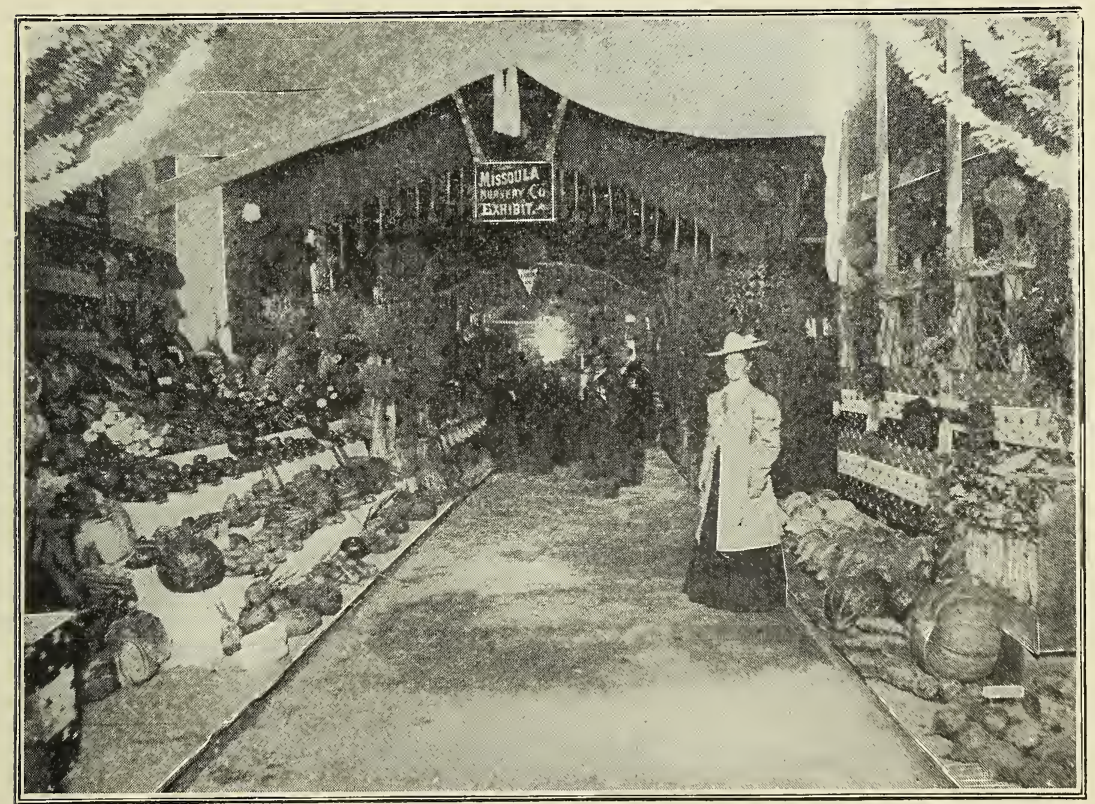

OUR EXHIBIT AT THE STATE FAIR, 1909 
apart each way. Planted thus, and the ground made rich, the profit in currants is large. Growers should also see that the bushes are pruned annually. Surplus weak branches should be cut away entirely, and the new growth shortened. Pinch off the tops of young canes in June to form fruit buds. This will allow a free circulation of air, and the currant worm will be seen as soon as it begins its ravages, whereas were the bushes thick they might pursue their depredations until most of the foliage would be consumed before notice.

Extra Large Special Selected, each, 50c; 10, $\$ 4.00$.

\begin{tabular}{|c|c|c|c|c|}
\hline & Each & $\begin{array}{l}\text { Per } \\
10\end{array}$ & $\begin{array}{l}\text { Per } \\
100\end{array}$ & $\begin{array}{r}\text { Per } \\
1000\end{array}$ \\
\hline years old, strong & $\$ .35$ & $\$ 3.00$ & $\$ 25.00$ & $\$ 150.00$ \\
\hline year old, strong & .. .30 & 2.50 & 20.00 & 100.00 \\
\hline
\end{tabular}

Black Champion-The fruit is large and of a superior quality; the bush is a vigorous grower and enormously productive, rendering it very profitable.

Fay's Prolific-Originated in Chautauqua county, N. Y. A cross between Cherry and Victoria. Of large size, fine flavor and claimed to be five times as prolific as the cherry. A great acquisition.

Perfection-The only small fruit ever awarded the Gold Medal of the Western New York Horticultural Society. A cross between Fay's and White Grape, retaining the valuable characteristics of both parents. Beautiful

bright red, as large or larger than Fay's, holding its size to end of bunch; easy to pick; a great bearer, superior to any other large sort; less acid and of better quality than any other large currant in cultivation. Large, healthy foliage, intermediate in growth between Fay's and White Grape. Kept well cultivated and fertilized they will regularly produce heavy crops of extra size fruit of the very best quality.

White Grape-Very large; yellowish white; sweet or very mild acid. Excellent quality and valuable for the table. The finest of the white sorts. Very distinct from the white Dutch, having a low, spreading habit, and dark green foliage. Very productive.

\section{GOOSEBERRIES}

Extra Large Special Selected, each, 50c; $10, \$ 4.00$.

\begin{tabular}{|c|c|c|c|c|}
\hline & & Per & Per & Per \\
\hline years old, strong & $\$ .35$ & $\$ 3.00$ & $\$ 25.00$ & \\
\hline year old, strong. & .30 & 2.50 & 20.00 & 150.00 \\
\hline
\end{tabular}

This fruit is so useful for cooking, when green or ripe, and it may be canned with such facility that it is beginning to be cultivated very extensively for both use and market.

Gooseberry culture is similar to currant culture-see pages devoted to currants. Plant early, cutting back tops severely. No fruit is more desirable for the home garden, for sauces, jams and pies.

Industry-The most planted in this country of any English sort, and is less subject to mildew. The bush is strong, upright, and immensely productive. Berries are of the largest size, dark red, and of excellent quality, rich and agreeable. When properly grown it produces large crops annually. It is one of the best varieties for general culture. 
Houghton-An enormously productive and always reliable, old variety. Of vigorous growth, slender and spreading, not subject to mildew. Fruit of medium size, smooth, pale red, tender and of good quality. About equal in hardiness to American varieties.

Pearl-Same color Downing; seems to possess all the good points of that variety with a little larger fruit and rather more prolific.

Josselyn-Red Jacket-An American seedling of large size, smooth, prolific and hardy, of best quality. Has been well tested over a wide extent of territory by the side of all the leading varieties, and so far the freest from mildew, both in leaf and fruit, of them all. A wonderful cropper, with bright, clean, healthy foliage.

Downing Gooseberry-Is the largest and best of all native American varieties. This valuable variety originated with Charles Downing, the greatest of all pomologists. The value of Downing lies in its large size, fine quality, beautiful appearance, vigorous growth and freedom from mildew.

Smith's Improved-Large, very good and productive.

\section{TESTIMONIALS.}

Missoula Nursery Company.

Whitehall, Montana, May 31, 1913.

Enclosed find check for $\$ 2.00^{\circ}$ for gooseberries. Thanks for promptness in filling order. I am curious to know the name and nature of the green plant you sent with the poplar trees. Hope it is something nice. Do you carry an assortment of shade trees in stock? If so, send me list, I might want a few another year. Am just fixing up my yard and starting an orchard-a small one. Very truly,

\section{E. J. STANLEY.}

Whitehall, Montana, May 21, 1912.

Missoula Nursery Company.

The gooseberries, and everything else, arrived in fine shape. If not too late I wish you would express me one dozen cherry currants-good variety. Splendid rain here-long drought broken-everything looking fine.

Respectfully,

E. J. STANLEY.

\section{RASPBERRIES}

Raspberries, both red and black, are among the most easily grown of any of the small fruits. The black raspberry requires more room between the rows than the red, owing to its spreading character, and yet if properly pruned it may be kept low growing and within limited space. The red raspberry sells for higher prices ordinarily than the black, but the black usually yields more crates per acre than the red. Black raspberries should be planted three feet apart in the row and seven feet apart between the rows, for field culture. Red raspberries may be planted four to five feet apart each way, cultivated both ways. A few acres of raspiberries, both black and red, may be profitably marketed in any rural community, and will be found exceedingly profitable. It does not require any special knowledge of fruit growing to succeed with the raspberry. SOIL-Raspberries succeed on almost all good soils, yet they should have one which is well drained but moist and easily worked. A sandy or clay loam is excellent. The one thing which they will not abide is a wet, heavy soil, or standing water about the roots. When planting the black raspberry plant, the top of root where new 
shoots start should be the part most observed. Let the germ be covered two inches with light moist soil and the soil about the roots trod firmly.

Extra Large Special Selected, each $25 \mathrm{c}$.

\begin{tabular}{|c|c|c|c|}
\hline & $\begin{array}{l}\text { Per } \\
10\end{array}$ & $\begin{array}{l}\text { Per } \\
100\end{array}$ & $\begin{array}{r}\text { Per } \\
1000\end{array}$ \\
\hline rong plants &.$\$ 1.00$ & $\$ 5.00$ & $\$ 30.00$ \\
\hline
\end{tabular}

Golden Queen-This variety is a seedling of the Cuthbert, but the color of the fruit is a rich, golden yellow.

Loudon-Pronounced the best early Red Raspberry by many of the leading horticulturists. Plant is a strong grower, very hardy and productive. Berry is firm, a good shipper; large size, beautiful bright scarlet color, ripens with the earliest.

Marlboro-The largest early Red Raspberry, ripening only a few days after Loudon; beautiful bright scarlet, of good but not high quality; hardy and productive.

Cuthbert, or Queen of the Market-A remarkably strong, hardy variety; stands the northern winter and southern summers equal to any. Berries very large, measuring three inches around, conical, rich crimson: very handsome and so firm they can be shipped hundreds of miles by rail in good condition; flavor is sweet, rich and luscious. The leading market variety for main crop.

Strawberry-Raspberry-One of the recent introductions from Japan. Seemingly a hybrid between strawberry and raspberry. Bush dies to the ground in the fall. Fruit red, in size and shape like a strawberry. Strawberry-Raspberry (new) each 50 cents; per $10, \$ 3.00$

\section{BLACK CAPS}

Gregg-Of gocd size, fine quality, very productive and hardy. It takes the same position among the black caps as Cuthbert among the red sorts. No one can afford to be without it.

Kansas Black Cap-Claimed to be the largest Raspberry known. Selected specimens measure one inch in diameter, while they are uniformly very large; extremely hardy, undergone a temperature of sixteen degrees below zero, unprotected, without injury. Immensely productive.

\section{BLACKBERRIES}

Extra Large Special Selected, each, 50c and up.

$\begin{array}{ccccc} & & \text { Per } & \text { Per } & \text { Per } \\ & \text { Each } & 10 & 100 & 1000 \\ \text { Strong plants } & \$ .25 & \$ 1.00 & \$ 5.00 & \$ 30.00\end{array}$

Snyder-Extremely hardy and enormously productive; medium size; no hard, sour core; half as many thorns as Lawton or Kittatinny, and they are nearly straight and short.

Stone's Hardy-This superior Blackberry originated in Wisconsin and can be relied upon as being very hardy, fine quality, sweet and marvelously productive. 


\section{LOGANBERRIES}

\begin{tabular}{|c|c|c|c|c|}
\hline & Each & $\begin{array}{l}\text { Per } \\
10\end{array}$ & $\begin{array}{l}\text { Per } \\
100\end{array}$ & $\begin{array}{r}\text { Per } \\
1000\end{array}$ \\
\hline Strong plants & $\$ .25$ & $\$ 1.50$ & $\$ 10.00$ & $\$ 40.00$ \\
\hline
\end{tabular}

\section{DEWBERRIES}

Extra Large Special Selected, each, 50c and up

\begin{tabular}{|c|c|c|c|c|}
\hline & Each & $\begin{array}{r}\text { Per } \\
10\end{array}$ & $\begin{array}{l}\text { Per } \\
100\end{array}$ & $\begin{array}{l}\text { Per } \\
1000\end{array}$ \\
\hline Strong plants & $\$ .25$ & $\$ 1.50$ & $\$ 10.00$ & $\$ 40.00$ \\
\hline
\end{tabular}

Lucretia-A long-growing, trailing Blackberry. The fruit. is very large, soft, sweet and luscious, with no hard core. Plant is hardy and productive.

\section{STRAWBERRIES}

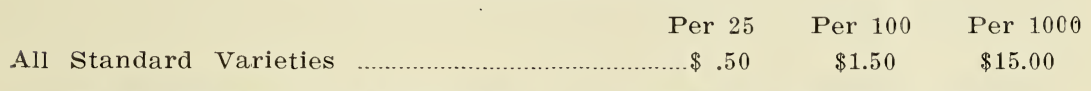

Those Marked (P) are imperfect. All others are perfect flowered.

Strawberry Culture.-We advise for field culture to plant in rows $3 \frac{1}{2}$ feet apart, with plants about 18 inches apart, about 8000 plants to the acre. For garden culture rows may be 3 feet apart, along border of the paths, if room to cultivate or hoe. Some prefer the hill system, but generally the rows found most profitable are the rows where the young plants are allowed to form a thick row known as the matted system. The soil should be made rich. Strawberries planted in the spring should be kept hoed or cultivated until winter sets in. At the approach of winter plants should be covered with a slight covering of strawy manure, free from weed seed, and a light furrow or shovel plow mark made between the rows to draw off surplus water, which is very injurious to strawberries during the winter and early spring.

Bubach-One of the best. Quite large plants, very robust; color dark green; has never shown signs of rust or blight. We can recommend it for field culture as well as for the garden.

Bismarck-Needs a strong soil to mature its crops of large, luscious berries. Seedling of Bubach with perfect blossom, larger, equally as productive, better in shape, color and quality; holds up well in shipping. Well tested; will please everyone that gives it a rich soil and good culture.

Brandywine-A fine, large, late, handsome, productive berry of excellent quality; regular conical form; dark, glossy red, extending to the center. Plant healthy and vigorous, abundant producer. An extra good sort for all purposes.

Crescent Seedling-(P.)-Large, averaging larger than Wilson's Albany; concial, color a handsome bright scarlet; quality very good. In productiveness unequalled, having produced over 400 bushels per acre. Plants very strong and vigorous. A most valuable market sort.

Senator Dunlap-(P)-(Medium Early)-One of the best all-round berries now on the market. The plant is perfect, not large, but tough, a rampant runner and ready to grow under any circumstances. It is wonderfully productive and every berry is generally brought to perfection. The fruit is beautiful, bright red and glossy, as regular as if cast in a 
mould, and of delicious quality. Large, but not the largest; firm, a good shipper and splendid keeper, and when canned one of the richest verieties we ever saw. It begins to ripen early and continues a long time in bearing.

Haverland-(P) -A favorite variety with many for near market. Very productive and profitable. Makes plants fast and ripens with the early varieties.

Hood River-This new berry originated at Hood River, Oregon, where it is planted to the exclusion of all others, for long distance shipments. It is larger than the Wilson and is very firm. Color a beautiful dark red and in quality is unsurpassed.

Gandy-Tate. Considered the best long keeping and one of the best shipping strawberries on the list. Its season is very late and it is in its prime when most other sorts are gone. Fruit is large, handsome and uniform and makes an excellent showing on the market. On heavy, rich soil the plant is a marvel of vigor and productiveness. The fruit stems are long and stand up well. Perfect.

Jessie-On rich ground and with good culture, this is a valuable sort. It is fairly productive and the berries average large, of great beauty and high quality.

Jaconda-(P)-This berry is of the Warfield type, has a perfect blossom, is hardy, productive, a splendid keeper and able to hold its own under any "rough and tumble" methods of culture to which it is likely to be subjected. Is a very heavy bearer of good size, even fruit, of a very beautiful dark red color. It is a berry to grow for either home use or market.

Sharpless-Size large to very large, irregular in shape, dark red when fully ripe; succeeds well on any heavy soil with good culture. The good old kind so favorably known.

Warfield-(P)-Similar in color and some other respects to Wilson-being very firm-it can be shipped a long distance.

Wilson's Albany-Medium to large, dark red, very hardy, vigorous and productive. The most widely known and universally successful strawberry.

Wm. Belt-A large, handsome, productive berry for market or home use. Vigorous, thrifty, heavy plant, producing large crops under good common matted row culture. Berries extra large, conical, quite uniform in shape, brilliant glossy red; ripens all over without green tips; good quality; carries well to market and brings highest price. One of the best varieties.

\section{TESTIMONIALS.}

Mr. C. F. Dallman, Missoula, Mont.

Ronan, Montana., May 2, 1912.

Dear Sir: The strawberries received in fine condition. Please find enclosed check for $\$ 3.00$ as per bill. Thanking you for your prompt attention,

Sincerely yours,

IV. SAMUEL TESTER.

Chinook, Montana, May 15, 1912.

Received strawberry plants in good condition. Would like to know where to send the money for them. Must it go to the agent in Big Sandy or to Missoula. Yours truly,

GEO. RICE, Chinook, Mont. 


\section{GARDEN ROOTS}

\section{ASPARAGUS}

There is probably no vegetable that is so absolutely superb to the delicate appetite of the epicure as the first delicious cuttings of early asparagus, and no vegetable more beneficial as an appetizer to persons of sedentary habits, and it is difficult to account for its cultivation being so much neglected by the community at large. In country gardens it is more rarely to be flound than any other vegetable, although so healthful and nutritious; yet everyone who knows anything about gardening, having a plat of ground should have an asparagus bed. While it is well known that asparagus will grow almost anywhere if covered with soil, yet the better you prepare the bed on the start the more likely you will be to have a bed that will last for years, from which you can cut an abundance in the early spring. In planting, let trenches be opened about two and one-half feet or more apart, about one foot in width and six or eight inches in depth. At the bottom of the trench some two or three inches of well decayed manure should be placed and well mixed with the soil. On this the plants are set about twelve or eighteen inches apart, spreading the roots out in a natural position and covering with two or three inches of soil, thus leaving the crown of the plant two inches or more below the level of the soil. These plants must be well cultivated, and at each hoeing, let a little earth be drawn into the trenches, so as to gradually fill them. About the end of October the stems should be cut off, and if the trenches are not already filled, fill them with well decayed manure, or good, rich compost. The second season, cultivate and hoe frequently.

\begin{tabular}{|c|c|c|c|}
\hline & Per 10 & Per 100 & Per 1000 \\
\hline Asparagus & $\ldots \ldots \$ .50$ & $\$ 4.00$ & $\$ 20.00$ \\
\hline
\end{tabular}

Conover's Colossal Asparagus-The good old variety, well known everywhere; it is of good size, rapid in growth and of good quality.

Palmetto Asparagus-This variety is considered by some to be the best. For this reason it is being largely planted now, both for home and market. It is a mammoth variety, of recent introduction, noted for its earliness, large size and productiveness.

\section{RHUBARB_Pie Plant}

$\begin{array}{ccc}\text { Per } 10 & \text { Per } 100 & \text { Per } 1000 \\ \text { Rhubarb } & \$ \ldots .00 & \$ 50.00\end{array}$

And who does not know the value of Rhubarb? In the early spring it is a very valuable addition to the larder for pie, sauce, etc. It is also put up in cans in cold spring water without cooking or sugar and kept in good condition for months or years until needed. Every housewife should learn thow to can rhubarb. How nice it is to be able, when tired of the other fruits, to make a rhubarb pie or pudding as an extra choice dish for a winter dessert. It cannot be fully appreciated until surprised with it some winter day, while it is associated in your mind only with the spring.

Myatt's Linnaeus-This is an extra good, early variety; large, tender and delicately flavored. 


\section{TESTIMONIALS.}

Dr. S'-vey, Dentist.

Great Falls, Montana, April 26, 1912.

Missoula, Nursery Co., Missoula, Mont.

Dear Sir: I received the stock all in first class condition yesterday, and I must say the quantity and quality was more than I expected. Before I knew there was a nursery at Missoula I had ordered some stock from other nurseries through their agents and the poorest rihubarb stock you sent me would make more than three like the best I got of them, yet the prices I paid them was double your prices. The grapes are excellent and Mrs. Stukey was more than pleased for the complimentary rose and carnation. I wish to thank you for the courteous treatment and will order when I need more stock. I certainly know where to get it. Yours very truly,

PETER STUKEY, D. D. S.

Missoula Nursery Co., Missoula, Mont.

Ronan, Montana, May 17, 1912.

Dear Sir: Enclosed find check for $\$ 1.80$ in payment of rhubarb and horseradish. Strawberry plants received all O. K.; planted the same day I received them and the most of them are living and doing fine. Thanks for the plants replaced. I am Yours respectfully,

C. T. PETTERSON,

Ronan, Mont.

\section{HORSERADISH}

\begin{tabular}{|c|c|c|c|}
\hline & Per 10 & Per 100 & Per 1000 \\
\hline Horseradish & $\ldots \$ 1.00$ & $\$ 8.00$ & $\$ 50.00$ \\
\hline
\end{tabular}

Many know what a nice relish this is to eat with cold meats, but few have it growing when they can get it at any time. It will grow without culture, but will give best results if planted where it can be hoed, etc. Some dig roots in the fields but these do not realize how much larger and nicer if properly planted and cultivated.

\section{SAGE}

$\begin{array}{ccc}\text { Per } 10 & \text { Per } 100 & \text { Per } 1000 \\ \text { Sage } & \$ 8.00 & \$ 50.00\end{array}$

Folt's Mammoth-Housewives and sausage makers know the value of this garden plant. No garden is complete without it. Is easy to grow. A few plants once started will last forever. 


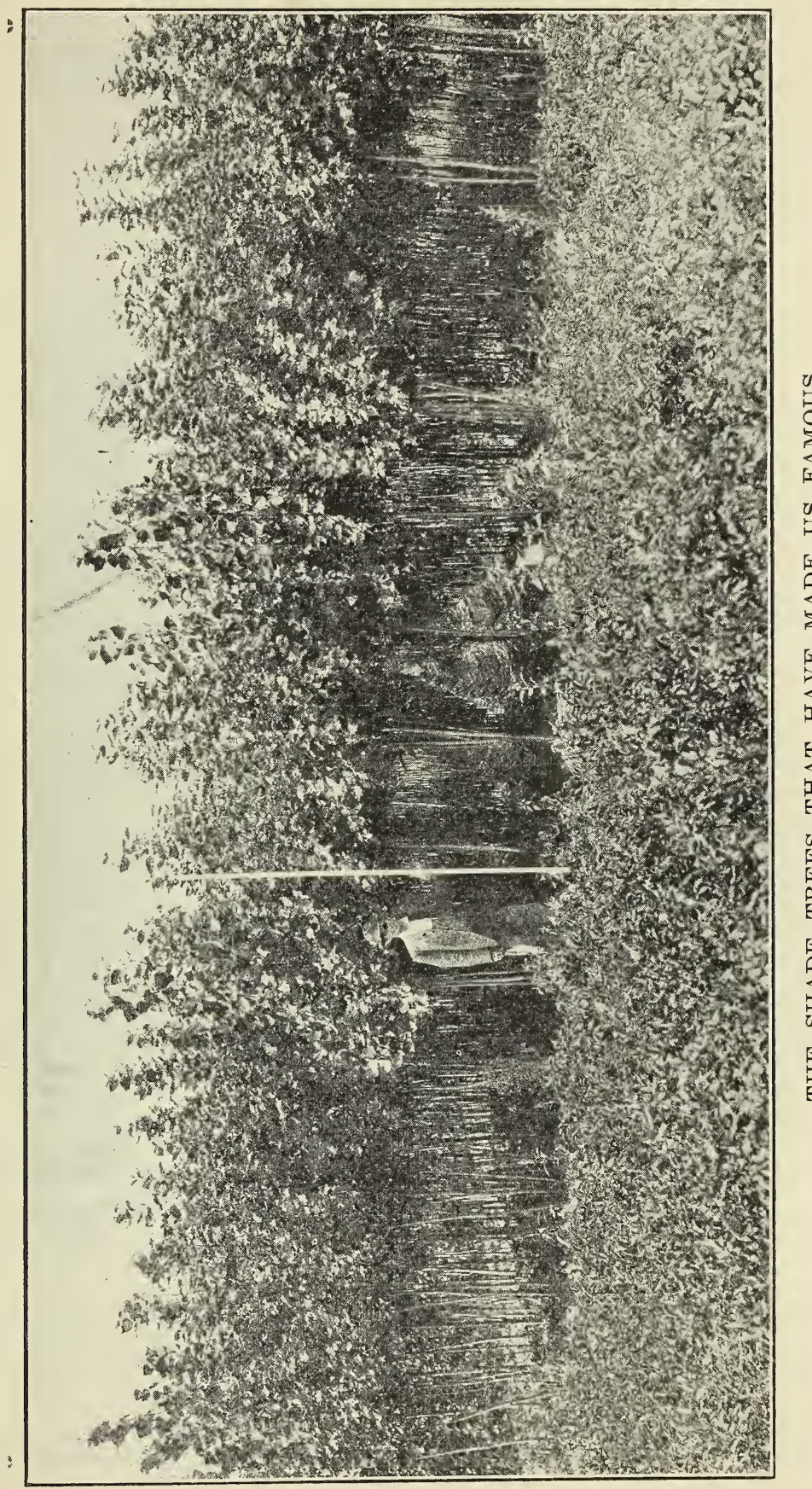




\section{SHADE TREES}

In this class we have some fancy specimens in the North Carolina Poplar, running from 3 to 6 inches in diameter, also in Box Elder and Soft Maple. These are all specimens and have been grown for years for particular trade. Prices of these will be given on application.

Extra Large Special Selected, each $\$ 1.50$ and up.

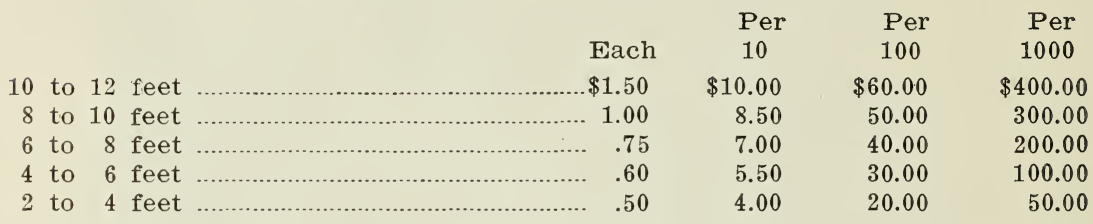

There is nothing that adds so much to the appearance and solid comfort of the home, and that will enhance the commercial value of property, either large or small, than the planting of beautiful shade trees, ornamental shrubs and roses. Realizing the growing demand for nursery stock of this nature, we have been giving careful attention to the selection and growing of such shade trees, shrubs, etc., that are best adapted for the various soils and climates of the Northwest; as a result we now have the following most desirable and valuable kinds and varieties to offer.

Poplar, Silver-Leaved-A vigorous, hardy tree of the Poplar family. Of rapid growth and spreading habits. The leaf resembles the Cottonwood in size and shape, but is more deeply lobed. Of a dark green on the upper side, and a silvery white beneath. The tree appears to be entirely at home in Montana.

Canada Poplar-This is the hardiest of all Poplar; iron clad in every respect; after several years of trial they have selected this variety as the most suitable at the celebrated Columbia Gardens at Butte, Montana. It surpassed them all in hardiness. We recommend them very highly.

Carolina Poplar-A vigorous, healthy native tree of rapid growth, pyramidal in form, with large, glossy leaves; valuable for park or street planting. Makes a fine spreading head if well cut back the first few seasons. Succeeds well everywhere.

Laurel-Leaved Willow-Handsome, upright tree with brown bark and foliage resembling the bay tree. Exceedingly effective when planted as a specimen.

Maple, Silver-A hardy, rapid-growing native tree of large size. Valuable for producing a quick shade. Excellent for street planting.

Maple, Ash-Leaved-(Box Elder)-A fine, rapid-growing variety, with handsome light green foliage and spreading head; very hardy, desirable for street plariting and succeeds in many sections where other varieties do not thrive.

Golden Willow-An exceedingly pretty and showy variety, with bark of bright golden color, making it very conspicuous during the winter. The catkins also are of yellow color. A handsome tree at all seasons. 
Poplar, Lombardy-A native of Europe. Remarkable for its erect growth and tall, spirelike form.

Poplar, Balsam-(Balm of Gilead)-A remarkably rapid-growing tree, luxuriant, glossy foliage.

\section{TESTIMONIALS.}

Missoula Nursery Co., Missoula Mont.

$720 \frac{1 / 2}{2}$ South Main, Butte, Montana, May 10, 1912.

Gentlemen: Please find enclosed money order for Nine Dollars $(\$ 9.00)$ to pay for the nine trees you sent me. I have been waiting, expecting a bill from you in regard to the freight, so if there is any freight to be paid please let me know and I will forward same to you. The trees are nice ones and came in good condition. Thanking you, I remain,

Yours very truly, ALF C. DAWE.

Mr. C. F. Dallman, Missoula, Mont.

Helena, Montana, April 20, 1912.

Dear Sir: Helena trees received in fine shape. Finished setting them out April 16, 1912. I enclose check for $\$ 122.10$. With kind regards, I am, Yours truly,

DANIEL BOYLE,

\section{WEEPING ORNAMENTAL TREES}

Extra Large Special Selected $\$ 2.00$ each and up Fancy specimens 1.50 each and up

Camperdown Weeping Elm-Its vigorous, irregular branches, which have a uniform weeping habit, overlap so regularly that a compact, roof-like head is formed. Leaves large, glossy, dark green. A strong, vigorous grower. The finest Weeping Elm and one of the best weeping trees.

Weeping Mountain Ash-One of the best known and most popular weeping trees. It is of easy culture, great hardiness and thrives in all soils. Its straggling branches, twisting and turning in every direction, with no training whatever, make a most picturesque and novel sight. Covered during the autumn with bright red berries. It is the best tree for the north of the extremely pendulous type.

Teas' Weeping Mulberry-The most graceful hardy weeping tree in existence. Forms a perfect umbrella-shaped head, with long, slender, willowy branches, drooping to the ground. It has beautiful foliage, is wonderfully vigorous and healthy; is one of the hardiest, enduring the cold of the north and the heat of the south; safe and easy to transplant, admirably adapted for ornamenting small or large grounds or for cemetery planting.

Cut Leaved Weeping Birch-This noble tree is not only the most popular of the weeping trees, but it is decidedly the best. Its tall, slender, yet vigorous growth, graceful, drooping branches, silvery-white bark, delicate foliage present a combination of attractive characteristics rarely met with in a single tree. It thrives in any soil and is very hardy, needing no protection. As single specimens on the lawn employed as avenue trees, they are very imposing and handsome. If one ornamental tree only, plant the Cut-Leaved Weeping Birch. 
Willow, Kilmarnock Weeping-(Umbrella tree)-This is a splendid weeping tree. Very desirable for lawns, gardens, cemeteries and wherever a drooping tree is preferred. It is often called the umbrella tree on account of the unique form. The leaves are glossy and reach to the extreme end of the drooping twigs which often touch the ground. It is hardy and vigorous, thriving on all soils. There are probably more of these trees planted than any other ornamental tree.

Wisconsin Weeping Willow-A beautiful tree with straggling, weeping branches. Makes a fine tree for the lawn or background.

\section{ORNAMENTAL SHADE TREES}

Extra Large Special Selected, each, $\$ 2.00$ and up.

\begin{tabular}{|c|c|c|c|c|}
\hline & & Per & Per & Per \\
\hline & Each & 10 & 100 & 1000 \\
\hline 10 to 12 feet & $\$ 2.00$ & $\$ 15.00$ & $\$ 100.00$ & $\$ 750.00$ \\
\hline 8 to 10 feet & 1.50 & 10.00 & 85.00 & 600.00 \\
\hline 6 to 8 feet & 1.00 & 8.50 & 75.00 & 500.00 \\
\hline 4 to 6 feet & .. .75 & $6 . \tilde{0} 0$ & 55.00 & 300.00 \\
\hline
\end{tabular}

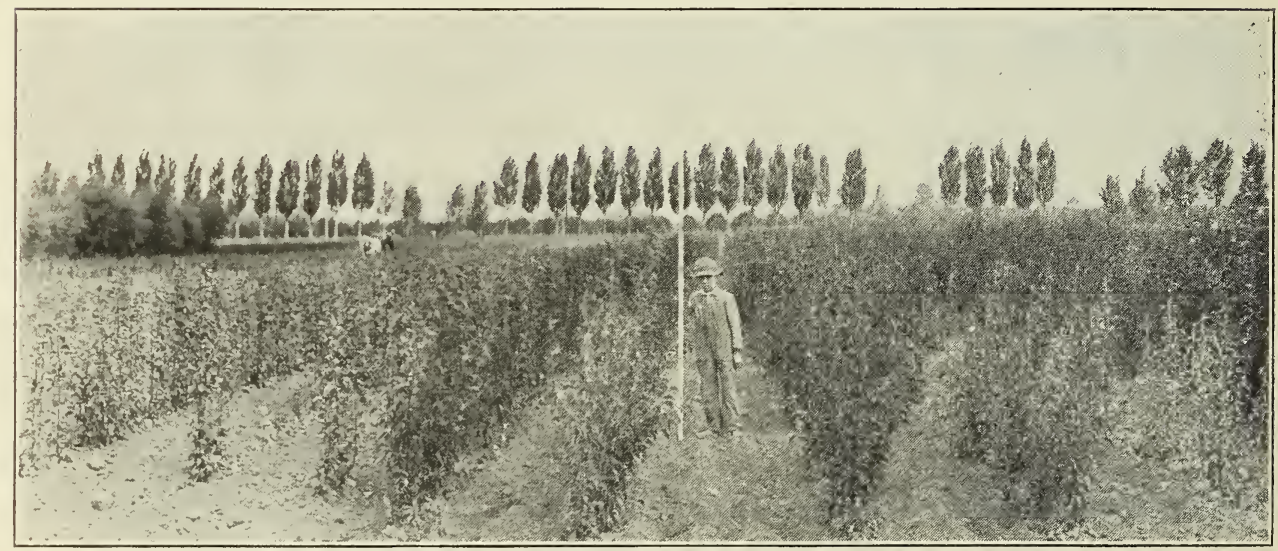

THE BROAD ACRES OF OUR NURSERY

European Linden-A very pyramidal tree with large leaves and fragrant flowers. A valuable tree for street and lawn planting, developing into beautiful specimens. Extensively planted for ornamental purposes and for bee pasture. Of rapid growth and not very particular as to soil.

Elm, American White-A native of South Dakota and the entire Northwest. One of our best trees for general planting for a shade or street tree; the best of the Elms; very hardy; endures well cold, drouth, wind and general neglect. Its wood is tough and valuable for some uses.

Ash, American Mountain-A native of the Black Hills. Similar to the European variety, but it is a little rounder-headed and more stocky in growth. It bears fruit in great abundance. The fruit or berry of the Mountain Ash is of no value for food, but is very handsome in appearance.

Ash, Oak-Leaved Mountain-A hardy tree of the pyramidal habit; height and breadth from 26 to 30 feet; leaf is deeply lobed, similar to the leaf of the Burr Oak; a very fine lawn tree. 
Norway Maple-For grace of form, beauty of foliage and grateful shade, no tree can excel the Norway Maple. Grows fast to a large size with spreading head and broad leaves which turn pale yêllow in autumn, but persist until severe weather. Its yellow flowers are a distinct feature.

Maple, Hard or Sugar-The Hard Maple is one of America's most beautiful and valuable shade and street trees. It is compact and uniform in shape and makes a dense shade. The foliage is a deep green during the summer, and this is followed by the beautiful red and yellow tints in the autumn.

Horse Chestnut-White flowering. A fine large tree of compact outline, dense, dark green foliage. In June the tree bears in greatest profusion large panicles of white flowers, tinged with red. Very pretty for street or lawn.

Locust, Yellow or Black-A valuable, rapid-growing tree; bears racemes of sweet-scented white flowers, making it quite desirable for a lawn tree.

Birch, European White-Its chalky-white bark and beautiful foliage makes it a desirable lawn tree. Very hardy where the ground is not too dry for it; a shallow rooting tree, as, in fact, all of the Birches are. Will stand almost any amount of cold, if not too dry.

\section{HEDGE PLANTS}

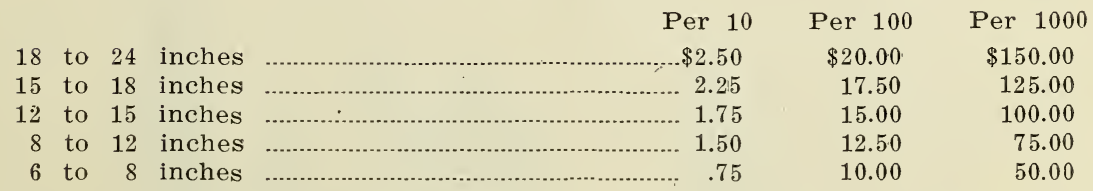

Spruce, Colorado Blue-This species has been tested at various points on the prairies of the West and Northwest with perfect success, and during a temperature of 30 degrees below zero, in exposed situations, entirely uninjured. One of the hardiest evergreens and the most beautiful in color and outline. "This is the king of spruces, clothed in royal robes of silver and sapphire, a very Kohinoor among the gems of the Rockies."

Japan Quince-Unquestionably a fine plant for an ornamental hedge. Grows very compact; will submit to any amount of pruning, while the brilliant and showy scarlet flowers make it exceedingly attractive.

Privet, California-The most popular of all ornamental hedges; used not only for hedges, but for grouping on lawn it is magnificent, as it can be sheared to any desired shape; its rich, dark green foliage is carried far into the winter; hardy, easily grown;

Arbor Vitae-An old favorite, too well known to need description. Suitable for single bushes or for hedging.

Balsam, or American Single Fir-A very regular, symmetrical tree, assuming conical form even when young. Leaves dark green above, silvery beneath. Very fine trees.

European Larch-(Larix Europaea)-An excellent, upright, rapid-growing pyramidal-shaped tree, with drooping, slender branches; foliage light green, soft and graceful in the spring, turning to a golden yellow in the autumn before falling. Unlike most conifers, it is deciduous after the first year; perfectly hardy, and thrives in nearly all situations. Makes a very handsome specimen for ornamental planting. 
White Pine-The most ornamental of all our native pines. Foliage light delicate or silvery green. Flourishes in the poorest soils.

\section{FLOWERING SHRUBS}

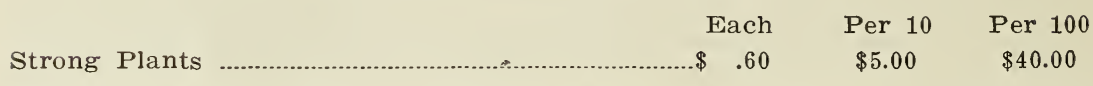

Barberry-(Purple-Leaved)-Foliage and fruit of a violet-purple color; very striking; fine for single specimens in the lawn; also a desirable orna. mental hedge plant.

Calycanthus-(Sweet Scented Shrub)-Flowers purple, very double and deliciously fragrant; remains in bloom for a long time; very desirable.

Deutzias-(Crenata)-Flowers double white, tinged with pink blooms in June. One of the fine hardy shrubs.

Hydrangea-(Paniculuata Grandiflora)-Generally considered the most valuable and ornamental shrub in existence. Bushy and robust, every branch tipped in mid-summer with an immense close panicle of flat, snow-white

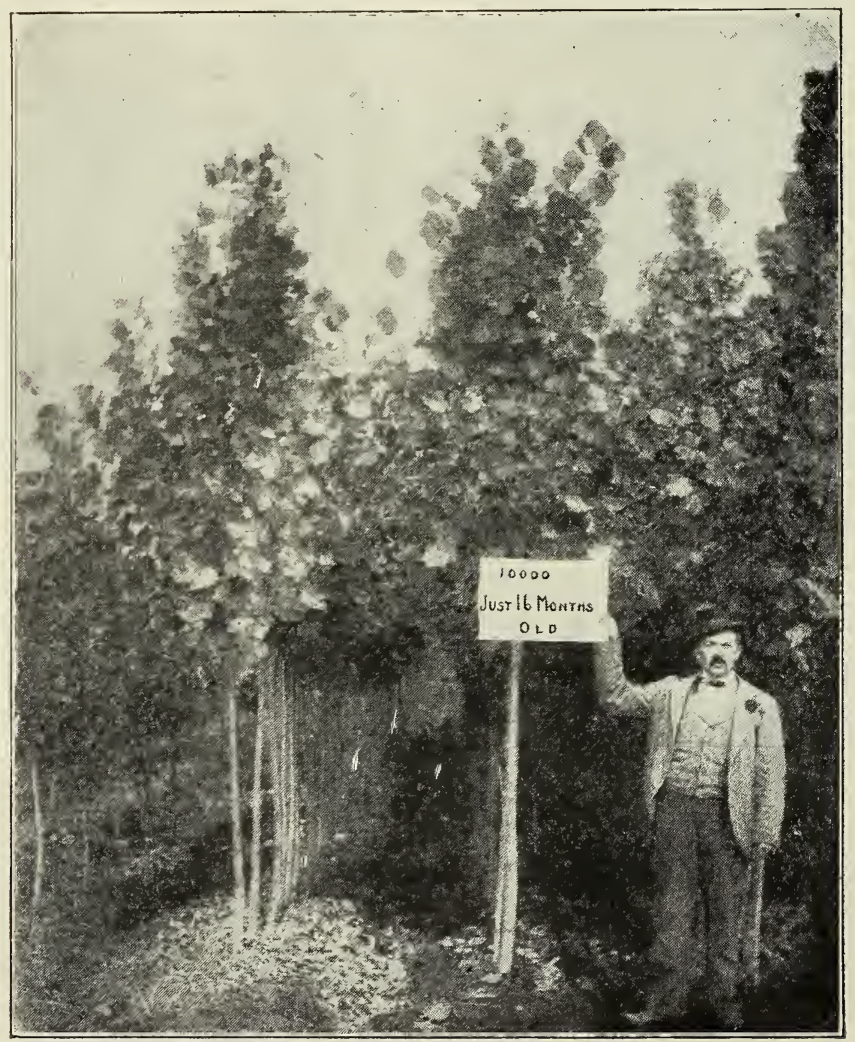

OUR POPLARS ARE STRONG AND STRAIGHT. 
flowers of gigantic size. The trusses of bloom are eight to ten inches long and are nearly as thick through. Begin blooming in July and lasts until November, flowers turning pinkish toward the last. No other shrub makes such a show on the lawn or is so universally admired. Hardy in any country, and always blooms finely the first summer.

Japan Flowering Quince-Bright scarlet crimson flowers in great profusion in early spring, and in the fall the bush hangs full of small golden quinces. Perfectly hardy anywhere.

Lilac, Purple-The well known variety. One of the best. A good grower. Flowers and young wood fragrant.

Lilac, White-A very desirable contrast to the purple.

Peonaes-Assorted, all colors.

Snowball-(Guelder Rose)-A well known favorite shrub, with globular clusters of pure white, sterile flowers, the latter part of May, each larger than a pure white snowball. This is popular and justly so, easily grown and attractive near by or at a long distance. It remains long in blcssom.

Upright or Bush Honeysuckle-(Red Tartarian)-Beautiful pink and rose colored blossoms in June, followed with bright red berries all during the season. Hardy.

Upright or Bush Honeysuckle-(White Tartarian)-Covered with white blossoms in May and June and is also covered with berries until fall. Hardy.

Spiraeas-(Anthony Waterer)-A new crimson flowered variety which is, in our estimation, one of the best dwarf flowering plants. It makes a low, compact bush two to three feet high and is covered from spring until late in the fall with large heads of deep crimson flowers. Perfectly hardy.

Spiraeas-(Van Houtte)-It is a beautiful ornament for the lawn at any season, but when in bloom it is a complete fountain of: white flowers, the foliage hardly showing. Perfectly hardy.

Weigelas-(Diervilla)-Candidia)-A vigorous, erect grower; flowers pure white, borne all through the summer months.

\title{
HARDY ORNAMENTAL CLIMBING VINES
}

\author{
Each, 60c; per 10, $\$ 5.00$; per $100, \$ 40.00$
}

Ampelopsis-(American Ivy or Virginia Creeper)-(Quinquefolia)-A native vine of hardy, rapid growth, with large, luxuriant foliage, which in autumn takes on the most gorgeous coloring. One of the finest vines for covering walls, verandas, etc.

Ampelopsis-(Veitchii)-(Boston Ivy)-Leaves a little smaller and more ivylike in form than the foregoing. The plant requires some protection until it is established.

Honeysuckle-(Red Coral)-A hardy, rapid grower, flowers are red and fragrant.

Honeysuckle-(Halleana)-A new variety from Japan, and has proved to be one of the best Honeysuckles grown. Blooms from June to November. It is almost evergreen and one of the most fragrant. White, changing to yellow. 
Clematis-(Jackmannii) - The flowers when fully expanded, are from 4 to 6 inches in diameter; intense violet purple, with a rich, velvety appearance, distinctly veined; flowers continually from July to Octoiber.

Clematis-(Paniculata)-(New, sweet-scented Japan Clematis) - No introduc* tion of recent years has met with such ready sale and given such satisfaction wherever planted. It grows and thrives anywhere and is a very rapid grower and profuse bloomer. Flowers are pure white, borne in large clusters, converting the plant into a perfect mass of white. Its extreme hardiness, bright green foliage and delightfully fragrant flowers serve to make this one of the finest hardy climbing plants in cultivation.

Wistaria-(Chinese Purple)-(Sinensis)-Most beautiful climber; of rapid growth, producing fine, large clusters of lovely blue in great masses. It is very hardy and one of the most superb vines ever introduced.

Wistaria-(Chinese White-(Sinensis Abla)-Flowers borne in long drooping clusters as in the purple variety; pure white in color making a most striking and elegant contrast.

\section{ROSES}

Strong, 2 years old

Each, 60c; per $10, \$ 5.00$; per $100, \$ 35.00$

More people appreciate the beauty and value of the rose than that of any other flower, and it is one of the easiest to raise in perfection.

It succeeds best in deep, rich soil, rather moist, with plenty of fine rotted cow manure and leaf mold, spaded in, every fall, banking up against each plant a foot or more with old, coarse straw manure for protection.

In the spring this manure should be spread on the surface of the bed and cultivated in; the result will be an abundance of rich, beautiful blossoms.

We offer the following carefully selected varieties, which have proved hardy with us. We send out one and 2-year-old strong plants on their roots.

\section{CLIMBING ROSES}

Baltimore Belle-This elegant climbing rose is a pale blush, variegated carmine rose and white. It is very double and flowers in beautiful clusters, the whole plant appearing a perfect mass of bloom. It is one of the very best climbing roses.

Crimson Ramblem-Perfectly hardy, wonderful free bloomer; rich flowing crimson. A most vigorous grower, making shoots 8 to 10 feet in a single season. As many as 30 and 40 flowers are seen in a single cluster.

Queen of the Prairies-Flowers are very large and of a peculiar globular form. A bright, rosy red, changing to lighter as the flower opens. Of very strong, rapid growth.

Seven Sisters-Blooms in clusters of seven or more flowers, varying from white to crimson.

White Rambler-(Thalia)-In habit of growth, foliage, manner of blooming and shape of flowers this is identical with Crimson Rambler, differing only in color, which in Thalia is pure, clear white. 
Yellow Rambler-This is the only hardy yellow climbing rose. Rapid grower; color a clear, decided yellow, changing to a beautiful cream. Blnoms in clusters same as the Crimson Rambler.

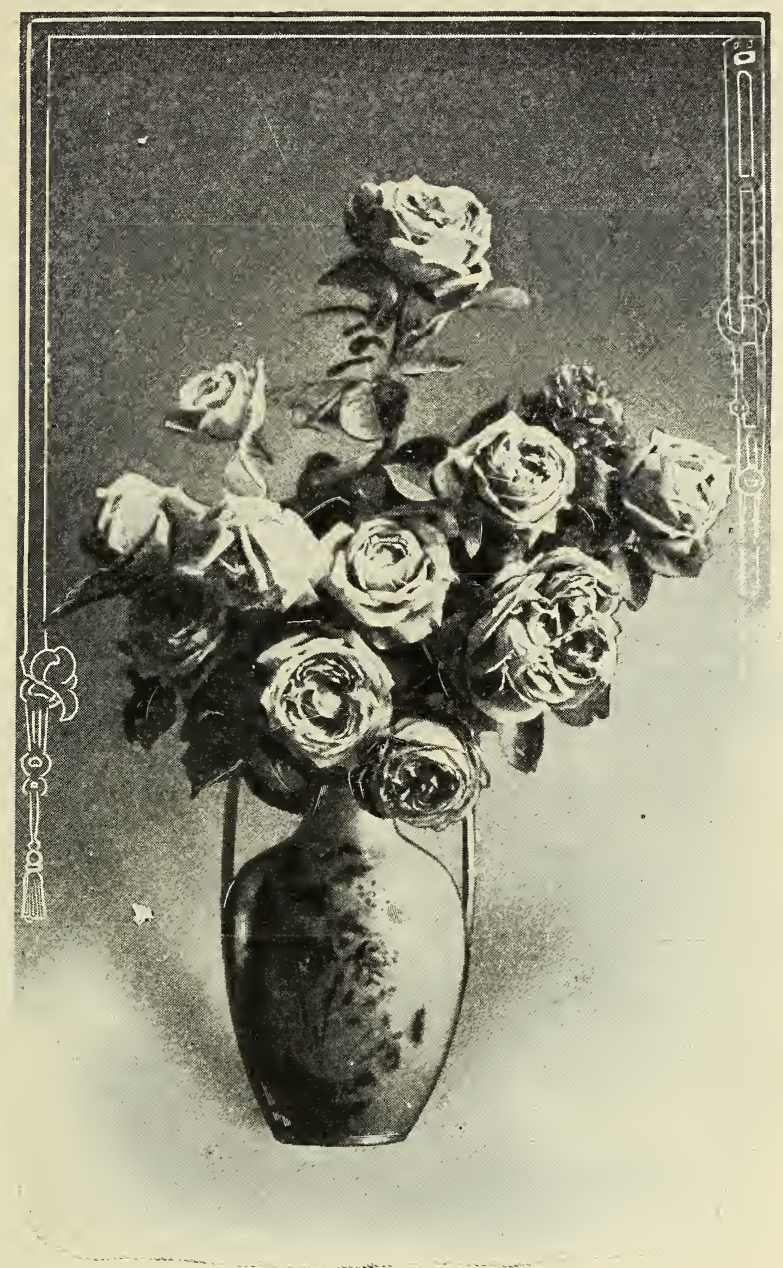

BEST OF ALL-THE GREAT AMERICAN BEAUTY

\section{HYBRID PERPETUAL ROSES}

American Beauty-Color rich, rose crimson, shaded and veined in the most charming manner. Hardy, free bloomer and very desirable.

Anna de Diesbach-Brilliant crimson, sometimes shaded with maroon; long pointed buds and large, finely formed flowers; extra fine.

Dinsmore-A vigorous; healthy rose of branching habit, very popular and highly recommended for garden planting as it is almost always in bloom. Flowers of a rich, bright crimson. 
Fisher Holmes-Dark, rich scarlet, elegantly shaded with deep, velvety crimson; beautiful. Extra large, full flowers.

General Jacqueminot-Large, velvety flowers of the most intense maroonscarlet, each set in a cluster of rich, green leaves. Blooms repeatedly through the summer and fall and is the most popular rose grown, without exception.

Magna Charta-A general favorite, prized on account of its strong, upright growing and bright, healthy foliage, as well as for its magnificent bloom. The color is a beautiful bright pink, suffused with carmine.

Madam Plantier-This grand variety; when once planted, is as hardy as a hydrangea. Flowers pure white, very large and double. One of the very best white roses.

Marshal P. Wilder-Color bright cherry-carmine; fragrant; of vigorous growth, with fine foliage. One of the freest of the Hybrid Perpetuals to bloom. We can recommend this rose without hesitation.

Mrs. John Laing-New. As a bedding rose this is undoubtedly one of the best varieties yet introduced, being hardly ever out of bloom all summer. Color a beautiful shade of delicate pink, of large size and very fragrant. It is also a good forcer from January onwards.

Paul Neyron-Immense double flowers, with a shining carmine pink; very double and fine-scented. The largest rose known.

Prince Camille de Rohan-One of the darkest colored roses; very dark, velvety crimson, changing to intense maroon. There is no rose in all this collection that attracts more favorable comment than this one. A very prolific bloomer and the blooms are of excellent form and size.

\section{TEA AND EVERBLOOMING VARIETIES}

La France-Perhaps no rose is better known and more highly valued than the La France. Both flowers and buds are of grand size. Color, a silvery-rose, changing to pink. A general favorite and the sweetest of all roses.

Bridesmaid-This is one of the most beautiful new Tea Roses that has been introduced in years. The growth is vigorous and very rich; healthy foliage and extra large flowers on long, stout stems; very double and simply exquisite when in bud or half-bloom. The color is a deep rosy pink, the inner side of petals silvery rose; makes charming bunches of long-stemmed flowers when cut.

Marie Van Houtte-Plant Marie Van Houtte if you want a rose that will bloom continually and furnish large, well-shaped, sweet-scented bloom. It succeeds anywhere and in any soil; an exceedingly strong, vigorous grower. Its color is creamy white, with the outer petals outlined bright rose; occasionally the entire flower is suffused with light pink.

Perle des Jardins-This magnificent Yellow Tea Rose still retains its position as one of the finest and most beautiful roses of its color ever produced. Its color is a clear golden yellow, and indescribably rich and beautiful shade, and entirely distinct from any other variety. The flowers are extra large, of great substance, and full to the center. Beautiful both in bud and open flower.

The Bride-A lovely, hardy Tea Rose and very popular. It has beautiful foliage and flowers of large size and most snowy-white.

Viscountess Folkstone-A vigorous, free-blooming, Hybrid Tea, of delicate tinted flesh color, almost white and lustrous as satin; large, delightfully sweet. 


\section{MOSS ROSES}

Crimson Globe-Rich, deep crimson.

Blanche Moreau-Pure white, large, full and perfect form.

\section{CREEPING ROSES}

Debutante-Of the many seedlings of Wichuriana introduced recently, this one promises to be one of the finest. It blooms freely under all conditions and makes one of the finest pillar roses imaginable. Flowers are quite double, pure white, borne in clusters. Very showy. Perfectly hardy, resembling its parent, Wichuriana, in this respect, but far surpassing it in freedom of bloom and form of flower.

Manda's Triumph-This is a grand variety. The flowers which are pure white and very double, are produced in clusters of from 10 to 12 on each cluster on small side shoots, literally covering the plant and standing iwell above the foliage.

Pink Roamer-A hybrid of the Sweet Briar, which it somewhat resembles in character of bloom, while the growth, which is very rampant, partakes more of the Wichuriana type. The single flowers are over two inches in diameter, a bright rich pink, with large, silvery white center and orange red stamens.

\section{ENGLISH SWEET BRIAR ROSE}

Highly prized on account of the delightful fragrance of its leaves and young branches. The flowers are single bright pink, very desirable for hedges and general garden planting.

\section{PERENNIAL PHLOX}

No class of hardy plants is more desirable than the Perennial Phloxes. They will thrive in any position and can be used to advantage in the hardy border, in large groups on the lawn, or planted in front of belts of shrubbery, where, by judicious pinching back and removing faded flowers, a constant succession of bloom may be had until frost.

Marie Belanger-Carmine, dark eye. An old variety, but very valuable for its vigor and floriferousness.

Michael Cervantes-Clear white with pure red eye.

Miss Lingard-Pure white, flowers very early. A standard sort.

Mme. Marie Kuppenheim-Pure white, a dwarf grower, and iate bloomer.

Mrs. Jenkins-A grand early variety, bearing immense panicles of pure white flowers.

Pecheur d'Islande-Crimson red suffused with cochineal red, bright carminered eye, very distinct.

Poussion-White, regularly striped rosy-pink, very fine.

Prof. Schliemann-Pure mauve with crimson-carmine eye. An effective late variety.

R. Werner-Rosy-carmine, dark eye. Large flower and truss, very striking.

Roxelane-Royal-purple, large flower. One of the best in its color, very effective. 
R. P. Struthers-Rosy-carmine with claret-red eye. One of the brightest and showiest.

Sunshine-Aniline red, a crimson red eye with a light halo in center.

Van Goethe-Tyrian rose suffused with carmine lake, carmine red center.

White Lady-Pure white. Tall grower, free blooming and late.

Wm. Muhle-Rich deep carmines purple; distinct crimson eve.

\section{HARDY PERENNIAL PLANTS}

\section{FOR PERMANENT PLANTING IN BORDERS OR BEDS}

There is an increasing demand for plants that are perfectly hardy, and do not have to be taken up every fall or replaced every spring. The following list has been selected with care and contains a fine assortment of plants that make valuable permanent beds.

Extra Fine Specimens, Each, $\$ 1.00$.

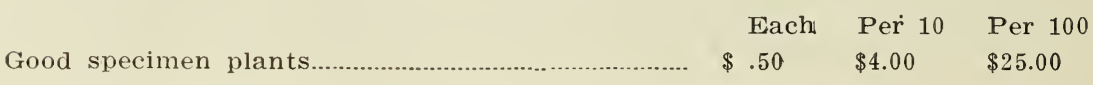

Peonies, Herbaceous-This is one of the most useful classes in the entire list. All hardy and showy, and very easily handled.

Price $\quad \begin{array}{ccc}\text { Each } & \text { Per Doz. } & \begin{array}{c}\text { Per } 100 \\ \$ 10.00\end{array}\end{array}$

Common Pink-A good sized pink flower; strong grower and quite desirable.

Common Red-A large-sized bright red double flower; a strong grower and perfectly hardy.

Ccmmon White-This is an early unnamed variety, and for a real good thing at a low price, we have nothing that will beat it. It is strong and vigorous in growth. Large, double flowers of a light pink tint with usually an orange-colored center, all changing to nearly a pure white after being open a few days.

Bleeding Hearts-(Dicentra Spectabilis)-A hardy perennial plant, producing long racemes of beautiful pink, heart-shaped flowers in May and Jure; an excellent border plant.

Orientale-(Orifntal Poppr)-The common variety. The flowers are a bright scarlet, 'with a black blotch at the base of each petal, and when in bloom in the spring they make a very brilliant display.

Hardy Poppies-(Papaver)-Nudicaule-(Iceland Poppy)-A beautiful race and among the most desirable of our herbaceous plants. The plant forms tufts of fern-like foliage, from among which the slender flower-stocks rise to about a foot in height and bear fragrant cup-shaped flowers. The profusion of blooms which they produce is astonishing, often a hundred flower-stems on a single plant, and they are produced from the beginning of June till October. They will thrive on any good garden soil, doing especially well in a sunny location. We offer them in the following colors: Scarlet, white and yellow.

Lathyrus (Latifolius)-(Perennial Pea)-Produces clusters of sweet-pea like flowers in colors of red, pink and white from June to September. 
Hardy Double English Violet-This violet is entirely hardy, perfectly double, a deep violet-purple color and most deliciously fragrant. It surpasses the well-known "Marie Louise" Violet in richness of color, being many shades darker, and far excels it in its delightful odor; this is one of its greatest merits. It is entirely free from disease of any kind, will grow and bloom in any garden and in any situation. Nothing is more arpropriate for cemetery plots than the Hardy Double English Violet.

Digitalis or Fox Glove-An old fashioned flower that should be planted in quantity. Succeeds under all conditions and furnishes a grand display during July and August. The flowers are very showy, with a large range of color and great variety of markings, from pure white to purple; thimble-shaped and borne close together on stalks from three to four feet high.

Canterbury Bells-(Campanula)-An old time favorite, growing 2 to 3 feet high and bearing in great profusion very pretty bell-shaped flowers. Shades of blue, white and rose, mixed.

Mammoth Fringed Hollyhock-(Allegheny)-The flowers are from four to six inches across, single and semi-double, finely fringed and curled. The colors are white, shell pink, rose and ruby red, crimson and maroon, a shade or two deeper at the center and tinted toward the edge. The blooming season is from June until frost.

Fleur-De-Lis, or Iris-The true "Fleur-de-Lis," the national flower of France. They are perfectly hardy, thrive anywhere, grow and bloom luxuriantly particularly if plentifully supplied with water or if planted in moist situations, as on banks of ponds, etc. Plants well established produce from 50 to 100 spikes of bloom, deliciously frangrant and fine for cutting. In beauty the flowers rival the finest Orchids, colors ranging through richest yellows, intense purples, delicate blues, soft mauves, beautiful claret reds, white, primrose and bronzes of every imaginable shade.

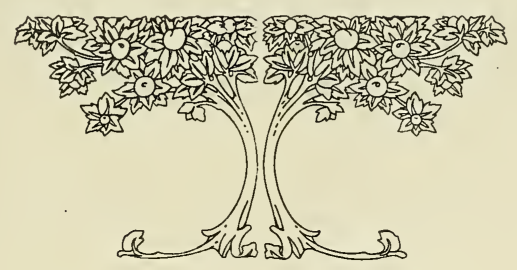




\title{
PLANT DEPARTMENT
}

COMPLETE IN EVERY RESPECT

All orders, unless instructions are received to the contrary, are executed and forwarded upon receipt. Customers placing orders for stock to be reserved and sent later must distinctly specify this at time of ordering.

\section{MISCELLANEOUS HINTS AND SUGGESTIONS FOR THE AMATEUR FLORIST}

\author{
By Chas. F. Dallman.
}

Soil for Pot Plants-It used to be thought and taught that nearly every kind of plant needed soil specially prepared for it. We have learned that this was a mistake. Ninety-nine out of every hundred plants that can be grown in the house will do well in any good soil that is not too heavy and compact to allow water to run through it readily. A soil prepared after the following formula will answer the needs of the flower-grower excellently: One part ordinary loam. One part leafmold of turfy matter. Mix these together and add enough sharp sand to make the whole so friable that it will fall apart readily after squeezing in the hand.

(The "turfy matter" advised as a substitute for leafmold is obtained by turning over sod and scraping away that portion of it which is full of grassroots. This gives you a light, spongy soil, rich in vegetable matter, and almost as valuable as genuine leafmold from the woods.)

A sprinkling of bone meal can be added to give richness, if thought advisable. But I think it best to wait until a plant has made some growth before using much fertilizer. When a plant is in the process of development one can tell better about its needs than he can in advance, and then is the proper time to supply those needs. At no time should enough be used to produce a rapid growth, for rapidity, as a general thing, means weakness. A sturdy, healthy development is what should be aimed at, and the wise gardener will be content with it.

Drainage-Every pot more than three inches across ought to have something in the way of drainage before filling it with soil, through which surplus water can run away. If the hole in the bottom becomes closed there is no outlet for this water, and the soil is soon soured by it. This results in diseased roots, and anything that interferes with healthy root-action will eventually destroy the plant unless the difficulty is promptly remedied. An inch of drainage is enough for a five-inch pot. For a ten-inch pot three is not too much. For intermediate sizes use proportionately. Old flower pots, or brick, broken into pieces as large as a walnut, make excellent drainage material. Coarse gravel can be used if there is nothing better to be hadalmost anything, in fact, that will not decay under the action of water. It is a good plan to put a layer of sphagnum moss or fine roots over the drainage material before filling the pot with soil, to prevent the latter from being washed down and closing the cracks and crevices through which the water is supposed to drain off, A piece of sod will answer if there is nothing better at hand.

Watering-Water when the surface of the soil looks dry, and then watering thoroughly, and waiting until the dry look comes again, is the 
nearest approach to a rule than can be offered. There are exceptions to all rules, and in order to take intelligent care of one's plants it is necessary to study them and be able to recognize the exceptions as they occur, and be governed in your treatment by the good judgment which can only come from personal olservation and experience.

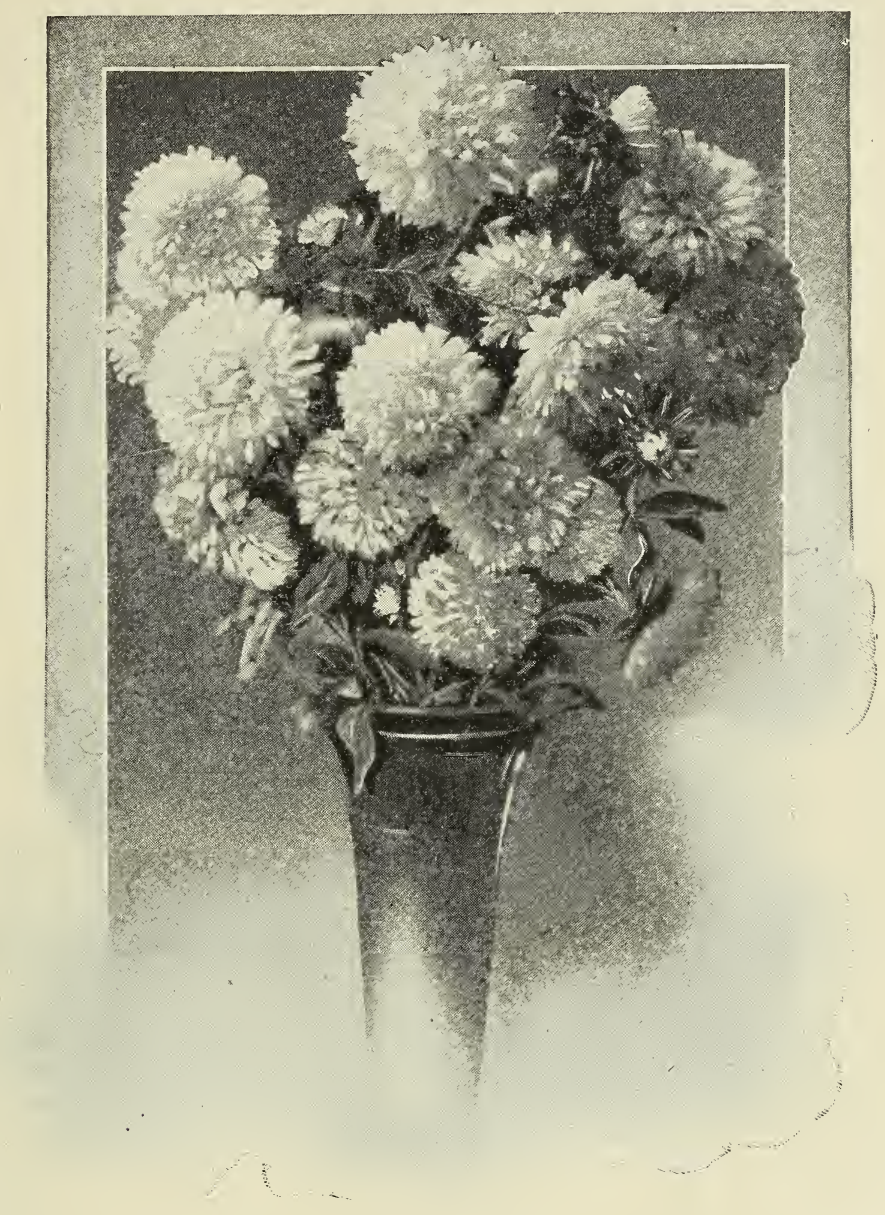

THE FALL QUEEN-THE CHRYSANTHEMUM

Plants in small pots dry out rapidly, and will require watering much oftener than those in large pots. In winter much less water is needed than in summer. Plants not making active growth will need but little water. Plants exposed to the sun will require a good deal more water than those in shade. Hanging plants almost always suffer from lack of water because the soil in them parts rapidly with moisture on account of exposure on all sides to a temperature considerably higher than that at the window-sill. Most failures with hanging plants and window-boxes outside the window 
result from insufficient watering. A window-box a foot wide, and a foot deep, and three feet long, ought to be given at least a pailful of water daily.

Repotting-I am not an advocate of frequent repotting. I prefer to supply my plants with food in the shape of fertilizers administered through the soil rather than forcing them to depend upon the soil itself for nourishment. If we make the soil the medium through which we feed our plants, it stands to reason that a frequent change of it is neither necessary nor advisable. My experience with root-bound plants which have been kept growing healthily by the application of fertilizers convinces me that a great deal of hard work can be saved by paying less attention to repotting than we have been in the habit of doing.

I would not be understood as saying that it is not necessary to repot a plant occasionally after it has grown to good size, but $I$ assert that it is wholly unnecessary to do so oftener than once in two or three years if the proper fertilizer is used.

Young plants will require shifting to pots of larger size as their root system develops. To not repot such a plant would be to check its growth at a time when the development of a vigorous root-system is a matter of great importance.

In repotting any plant, large or small, disturb the roots as little as possible. Slip it out of its old pot, put it into the new one, and fill in about it with fresh soil. Water well before doing this to prevent the soil from cleaving away from the roots. Water well after you have the plant in its new pot to settle the soil you have added.

Fertilizers-There are many good kinds on the market. I cannot mention any particular kind here with the exception of bonemeal which has already been spoken of. This I consider a thoroughly reliable plant food. Liquid manure made of leaching barnyard soil is excellent.

But let me say right here, use whatever fertilizer you make choice of with great caution. Be governed by the instructions which accompany it. Don't think that because a little is good a good deal must be better. It is an easy matter to kill your plants by being too kind to them. Don't try to force their growth.

Never use any fertilizer on a plant that is standing still. It is not in a condition to make use of rich food. Wait until it begins to grow, and then weak applications, increasing the amount as the plant develops. So long as plants grow well, be content to let well enough alone. Sickly plants are injured by the application of a fertilizer under the impression that what is needed is more food. They need no food at all until normal conditions are resumed. You will know when this takes place by their beginning to grow.

Insects-The insect most frequently met with among house-plants is the aphis or green plant-louse. Some plants, like the Rose and Pelargonium are especially subject to its attack, and unless it is properly checked they will be greatly injured by it. The preparation on the market under the name of Nikoteen is the best weapon I know of to fight this enemy of plant life with. Prepare and use it as directed on the bottle or package in which it comes; and it will certainly destroy every aphide with which it comes in contact. Keep a supply of it on hand, and make use of it whenever you discover an aphis. Do this promptly, and it is an easy matter to prevent the insect from spreading all over your plants, but wait a few days and you will 
find that the pest has increased a thousandfold. "A stitch in time saves nine."

If the leaves of your plants turn yellow and drop without any apparent reason for it, you are safe in suspecting that the red spider is the cause of the trouble. Turn up a leaf and examine it carefully. If you find tiny webs on it you may be sure your suspicions were well founded. So small is this creature that he will not be seen unless you look for him with sharp eyes. Even then he will resemble grains of Cayenne pepper more than a living organism. But, small as he is, he is capable of doing deadly work.

Nothing troubles the red spider but moisture. Showering-not sprinkling-with clear water will rout him if persisted in. Lay the infested planc down on its side and turn on the hose. Do this several times a week until the plant shows no more yellow leaves, and not a web is to be seen. But do not "rest on your laurels" when you have accomplished this much, but act on the belief that the enemy will soon return if you relax your vigilance. He 'will, at the first opportunity, if he considers it safe to do so. Keep water constantly evaporating on stove and register in winter. Do any and everything that will help to keep the atmosphere of the room moist, but depend upon showering as a general treatment.

Airing Your Plants-Give the plants in your window fresh air on every pleasant day. Open a door or window at some distance from them and let the cold air from out of doors mix with the warm air of the room before it reaches them. This is very necessary, especially in winter when our rooms are sure to be overheated, and the air in them is depleted of its life-giving qualities.

When Plants Are Received From the Florist do not take them out of their wrappers immediately, unless the soil about their roots is damp enough to hold together. Set them up on end and water them well. Leave them until the soil has had a chance to absorb a goodly amount of moisture, and then pot them, being careful to expose their roots as little as possible. In case the soil is so dry that it crumbles when they are received, I would put them in the cellar over night after watering them well.

We invite you to visit our establishment. This season we have doubled our glass area. Our stock was never as complete and in such perfect conaition as this season. They are cool grown, clean and healthy, well furnished and stocky, not to be compared with the lanky stock sent out. In placing an order with us you can always depend on it that we will select plants for you fully up to the value of our price, placing yourself in the same position as though you had selected them yourself. We treat each and every order received, large or small, as though it were the only order in the house. This state with its many protected valleys and rich soils offer places for homes that can be made beautiful. A home, however, small, with proper arrangements can be made an ideal one with Trees, Shrubs and Flowers. Surround your home with flowers and you will soon notice the peculiar refining influence they will have upon yourself and children.

\section{THE CANNAS}

The Cannas wherever planted in Montana have proved to surpass the greatest expectations and we wish to recommend them as one of the most prolific and beautiful flowering ornamental plants. We carry five varieties -Mad, Crazy Red, Chas. Henderson Red, Flamingo Red, Florence Vaughan Yellow Spotted, Italia Orchid flower, yellow with blood spots. 


\section{BEDDING PLANTS}

Per Doz. Per 100

Ageratum

$\$ 1.00$

$\$ 6.00$

Alyssum

1.00

6.00

Aster (transplanted)

.25

1.50

Carnations-(See Plants in Pots)

1.00

6.00

Cobea Scandens

Coleus, ten varieties

6.00

Feverfew

1.00

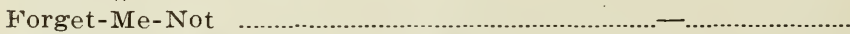

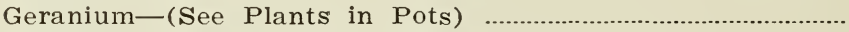

Heliotrope

1.00

6.00

Ivy-

English

1.00

6.00

German, good for outdoor culture

1.00

1.00

6.00

Lobelia

1.00

6.00

Lantana

1.00

6.00

Pink

1.00

6.00

Marguerites-(French · Daisy)

Yellow

1.00

6.00

White

Mignonette

1.00

6.00

Nasturtium-mixed colors

Dwarf, Climbing

Pansies-Extra fine plants in bud and bloom .......................... $\quad .50$

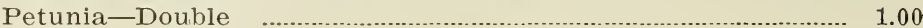

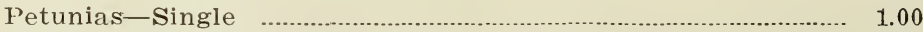

Phlox Drummondii

Salvia, Scarlet

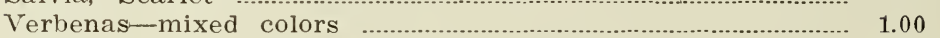

Tolets

California (single)

2.00

6.00

Marie Louise (double)

1.00

15.00

Zinnea-transplanted

1.00

6.00

6.00

1.00

6.00

Hyacinths, in jars and pots, all colors; when in season. $25 \mathrm{c}$ and up Tulips, in jars and pots, all colors; when in season. $.25 \mathrm{c}$ and up Daffodils, in jars and pots, all colors; when in season $25 \mathrm{c}$ and up Narcissus, in jars and pots, all colors; when in season $25 \mathrm{c}$ and up

\section{ASTERS}

We have always been noted for our Asters and during the past season we have added more of the best varieties to our beds. We have received many flattering testimonials as to their size and quality. The flowers are large and are supported by long, stiff stems. Can be supplied in separate colors or mixed. No family of plants bears such marks of progress as the Aster, and none is more eagerly sought. An almost endless variety; always reliable.

Comet, or Branching-A handsome and very distinct variety, resembling Japanese Chrysanthemums.

Crego's Giant Comet-Magnificent fluffy flowers, averaging over 5 inches across, with long strong stems; the finest of this type. Comes into 
bloom in August, continuing well into september, and unlike most of the Comet sorts, stands when cut and is a good flower to ship.

Improved Crego-In white, shell pink, rose pink and purple.

Queen of the Market-The earliest variety. Colors, white, pink, red, blue or mixed.

Truffaut's Paeony Flowered-Medium tall; deserves a place in every garden. The colors are bright and delicate. White, blue, indigo, rose, red.

Ageratum-(Floss Flower)-One of the very best bedding plants, being literally a sheet of bloom from early summer till frost. Unlike many bedding plants, their flowers are not liable to be spoiled by rain, nor do the colors fade out. The various blue varieties are without doubt the most satisfactory bedding plants of this color for our trying climate.

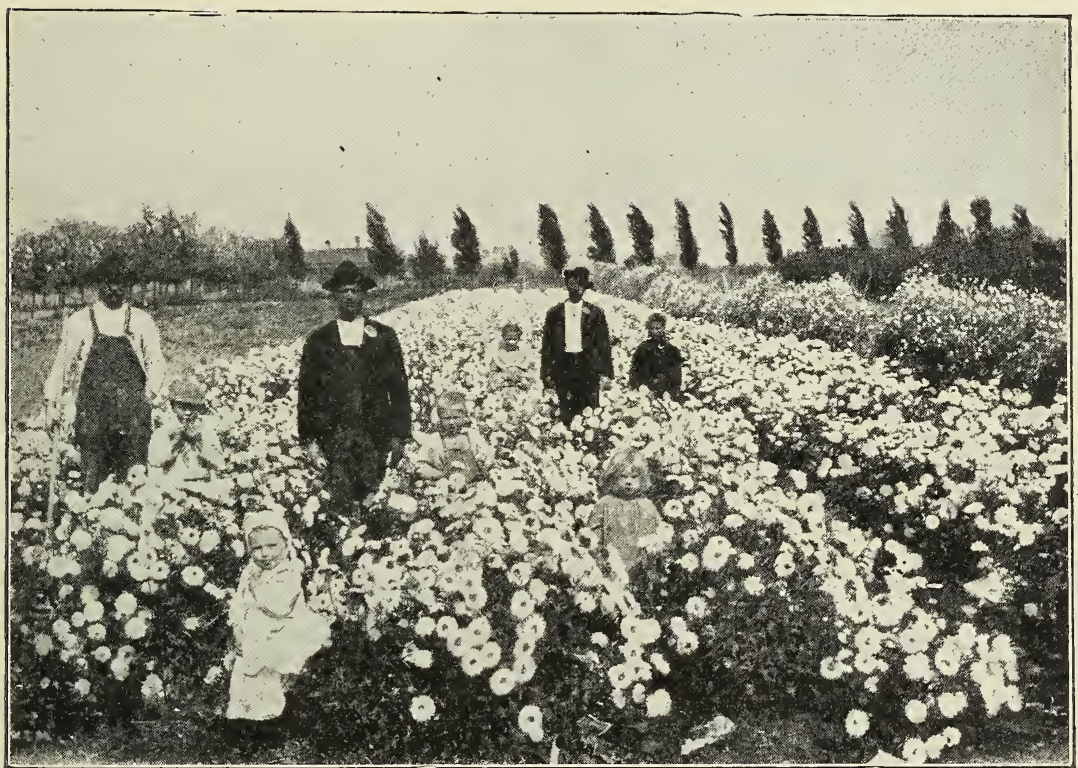

A FIELD OF ASTERS IN OUR OUT-DOOR GARDEN.

\section{ALYSSUM}

Mad Wort-Pretty little plants for beds, vases, baskets, edging or rockwork, blooming profusely all summer; useful also for winter-flowering. Very sweetly scented.

Little Gem, or Carpet of Snow-Of dwarf, compact habit, but four inches high. It begins to bloom when quite small, and the plants are a solid mass of white from spring to late in autumn, and undoubtedly the best white flowering edging plant in the list.

Balsam-The Balsam has been so much improved by cultivation as to be scarcely recognized. The blossoms are double, though semi-double and 
single ones are very certain to appear, and such plants should be removed. Require a rich, deep soil, good culture and plenty of space to grow to perfection. Height, 2 feet. Tender annual.

Canna-(All Leading Varieties)-Stately plants, with foliage of elegant growth, presenting a luxuriant and tropical appearance, and much employed in ornamental planting; when planted in clumps of 4 or 5 contrasting colors are very effective. Height 3 to 6 feet.

Cobaea-Scandens-A splendid climbing plant with large purple bell-shaped flowers and elegant tendrils; when well established grows very rapidly, with numerous branches. Height, 15 to 20 feet. Tender perennial.

Feverfew-A free-flowering, half-hardy perennial plant growing 18 inches in height. The plant throws up numerous stems, terminating in clusters of very double, pure white flowers, three-quarters of an inch in diameter. These are desirable for cut flowers. Plants bloom freely when grown in pots in a cool room.

Four o'Clock-(Marvel of Peru)-A handsome plant, making an attractive display of its many colored flowers from the middle of July till frost. The blossoms are marbled and spotted in the most diversified manner, the same plant producing different colors; some branches will grow flowers of a single color only, while others will have stripes. The leading colors are red, white and yellow with stripes and variegations of all three. Height, 2 feet. Hardy annual.

Forget-Met-Not-This beautiful little flower is too well known to require description or recommendation. The delicate blue flowers appear all summer. Height, 6 inches. Hardy perennial.

sophila-Small, fragrant flowers, borne on long feathery stems. No flower adds more of light and grace to a bouquet than this, and when once grown will be found indispensable. In bloom through the summer from the first of July till frost. Although not belonging to the immortelle class, the flowers dry finely and are very desirable for winter bouquets. Height, 1 foot.

Heliotrope-A well known popular house plant, fine for bedding, vases or baskets and exquisite for pot culture in winter. Flowers purple, borne in trusses, and exceedingly fragrant. Height, 1 foot. Half-hardy perennial.

Hibiscus-(Marshmallow)-Showy ornamental perennial plants, for mixed beds or shrubbery borders, having large-sized, beautifully-colored flowers; blooms the first year if planted early.

Hyacinth Bean-(Dolichos Lablab)-Splendid climber, with abundant clustered spikes of purple and white flowers, which are followed by exceedingly ornamental seed-pods. It is of rapid growth and often runs 20 feet in a season. Height, 10 to 20 feet. Tender annual.

Lobelia-(Crystal Palace)-An elegant and useful class of plants of dwarf, compact growth, bearing a profusion of delicate blue flowers. In bloom through the summer and autumn. Make a neat and effective edging for geraniums and ornamental leaved plants; pretty for baskets and vases and piazza decorations. Height, 6 inches. Half-hardy 7 ๆnial.

\section{MARGUERITES}

The Improved Crested-We grow this in the "White" or Queen Alexandra variety. 
Mrs. F. Sanders-Color of the purest glistening white, in size, blooms often measuring 5 inches across. Large double.

Marigold-A showy plant of compact, symmetrical growth, handsome foliage and a profusion of flowers of brilliant shades of yellow, finely variegated and striped with dark, rich colors of maroon and brown. Flowers are about an inch in diameter, full double to center, and cover the plant profusely. Height 1 foot. Half-hardy annulal.

Mignonette-(Reseda)-One of the best known and most popular flowers, indispensable for the garden; is suitable to almost any location and soil, furnishing its fragrant blossoms continuously through the summer and until after severe frosts. Height, 1 foot. Hardy annual.

Mourning Bride-(Scabiosa)-One of the best flowers for bouquets; plants of dwarf habit and compact; the flowers borne on long, wiry stems. A great variety of colors from white to very dark purple-almost black. In bloom from August till after severe frosts. Height, 18 inches. Hardy annual.

Nasturtiums-(Dwarf)-A bed of Dwarf Nasturtiums is very desirable for borders along walk ways, etc. They are in constant bloom. Grow about one foot high.

Pansies-Next to the Rose there is no other plant which enjoys such universal popularity as the Pansy. It is a favorite with all, having a larger assortment of colors than most other flowers. It is a hardy biennial; blooms continuously from spring until late in the fall, and will, if slightly covered, bring fine results the second year. No garden, however small it may be, should be without a bed of Pansies.

Petunia-One of the best flowers for a splendid display throughout the entire season. Beautiful new colors, striped and marked in the most diversified manner. The ease of culture, profuse and continuous blooms, adaption for different styles of growth - indoors and in the gardenrender the Petunia one of the most valuable of the annuals and entitled to a generous share of the space in every garden.

Phlox Drummondii-No flower excels this in all the qualities that make a popular annual. Brilliant and varied colors, continuous and profuse bloom, being one of the last to succumb to the frosts of late October. It is excellent.

Pyrethrum-(Insect Powder Plant)-Practical entomologists tell us they have found an effective and safe insecticide in the Persian Insect Powder. This is the dried and powdered flowers of the Pyrethrum Roseum, and it is certain death to Plant Lice, Flies, Cabbage Worms and nearly every form of insect life. It is harmless to man, but when diluted with ten times its bulk of flour, kills Cabbage Worms and other insects. Height, 1 foot.

Salvia-The Salvia or Scarlet Flowering Sage is a very ornamental plant, flowering in spikes, and continues in bloom in the open ground till frost, when the plants can be removed to the house and they will continue in bloom a long time.

Snap Dragon-They have dark and glossy leaves and curiously shaped flowers with finely marked throats. They bloom the first season from seed sown in the spring, but the blossoms will be much stronger the second year. Succeeds best in dry loamy soil. Half-hardy perennial. A few leaves or any light litter thrown over them will help to carry them through the winter; or they may be treated as annuals. 
Stocks-(Ten Weeks)-Plants grow about one foot high, making a compact bush, covered with splendid spikes of blooms from July till frost. Saved only from the selected plants, and will produce the largest proportion possible to obtain of large double flowers, in the most brilliant colors and variety. Half-hardy annual. Height 1 foot.

Verbena-The most popular bedding plant. The fine variety of colors, with stripes and markings of different colors, profuse and long continued bloom and excellence for bouquets, make them one of the most desirable annuals for general culture.

Violet-(Viola Odorata)-The violet should not be wanting in any garden, on account of its fragrance and early appearance. A single flower will perfume a whole room. Succeeds best in a shady, sheltered place, and

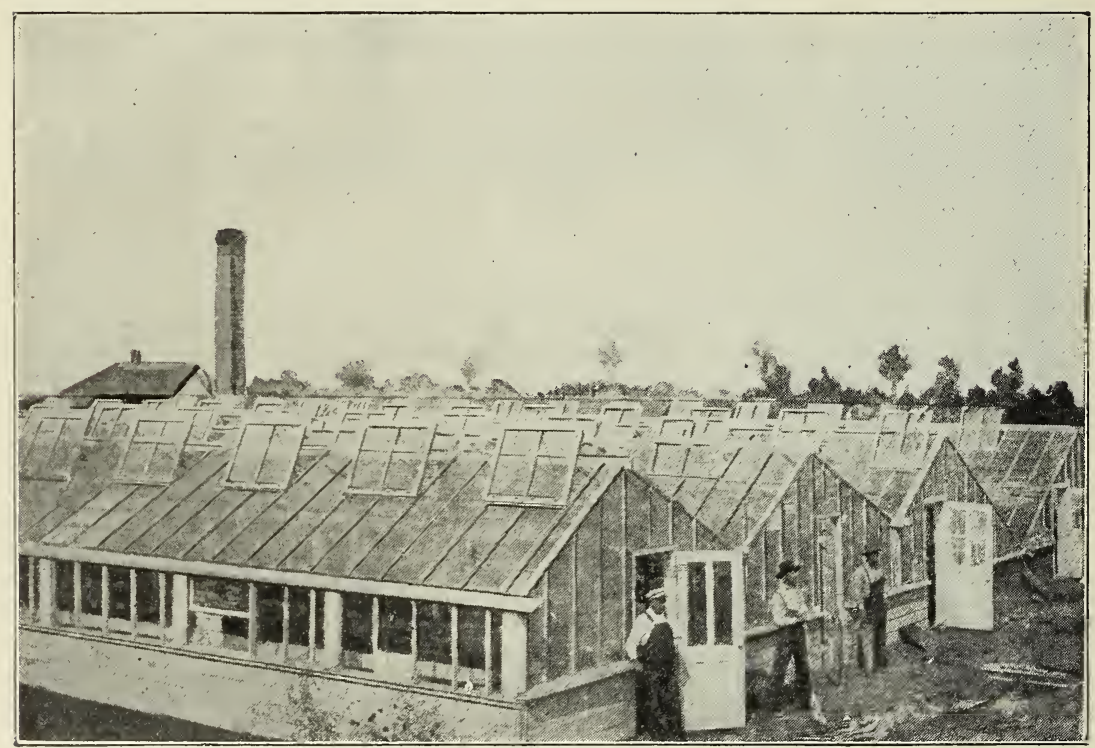

OUR CARNATION HOUSES.

can be easily increased by dividing the roots. The violet is an emblem of faithfulness. Hardy perennial. Height, 4 inches.

Wallflower-The large, massive spikes of the Wallflower are very conspicuous in beds and borders, and are very useful in making bouquets. They are deliciously fragrant, perfectly double, and combine many shades of color-the orange, purple and chocolate predominating. Height, 18 inches. Tender perennial.

Zinnia-Fine, large flowers, of great variety of colors-red, rose, crimson, scarlet, purple, orange, white and yellow-the flowers full double as a Dahlia, and remaining in bloom from July till frost. Make a fine display when grown in rows, the plants forming a dense hedge, covered with hlooms. Height, 2 feet. Half-hardy annual. 


\section{FLOWERING PLANTS IN POTS}

\begin{tabular}{|c|c|}
\hline & $25 \mathrm{c}$ and \\
\hline & $25 \mathrm{c}$ and \\
\hline Bonn & $25 \mathrm{c}$ and \\
\hline 然 & $\$ 2.00$ \\
\hline -Rex & $25 \mathrm{c}$ \\
\hline -Flowering & $25 \mathrm{c}$ \\
\hline 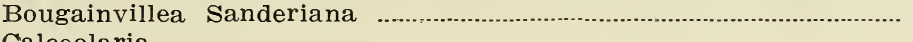 & \\
\hline i & \\
\hline
\end{tabular}

\section{Carnation-}

Beacon-red

$25 \mathrm{c}$ and up

Harlowarden-crimson

$25 \mathrm{c}$ and up

Enchantress-pink

May Day-pink $25 \mathrm{c}$ and up

Washington-pink

$25 \mathrm{c}$ and up

White Wonder-pink

$25 \mathrm{c}$ and up

Enchantress-white

$25 \mathrm{c}$ and up

Mrs. Ward-dark pink

$25 \mathrm{c}$ and up

$25 \mathrm{c}$ and up

Cineraria, well potted grown plants, in full bloom.

$25 \mathrm{c}$ and up

Easter Lilies, according to number of buds and blooms.

$50 \mathrm{c}$ and up

Fuchia-

Black Prince

$25 \mathrm{c}$ and up

Carl Halt

$25 \mathrm{c}$ and up

Storm King

$25 \mathrm{c}$ and up

Rose of Castile

$25 \mathrm{c}$ and up

Earl of Beaconsfield

$25 \mathrm{c}$ and up

Beauty of Exeter

$25 \mathrm{c}$ and up

Genista canariensis, when well grown a stately plant

$25 \mathrm{c}$ and up

Geranium-

Geranium as a bedding plant we can recommend very highly; always in bloom, brilliant in color and easy culture. For cemetery planting the Geraniums are undoubtedly the best plants to recommend.

Prices

S. A. Nutt-dark scarlet (double) ….... $\$ .15$

Mme. Thibaut-pink (double) ….............. $\quad .15$

Mrs. E. J, Hill-single................................ .15

Mme. Jaulin-variegated ........................ .15

General Grant-scarlet (single)............... $\quad .15$

$\begin{array}{ccc}4-\text { in. Pot } & \text { 5-in. Pot } & \text { 6-in. Pot } \\ \$ .25 & \$ .50 & \$ .75 \\ .25 & .50 & .75 \\ .25 & .50 & .75 \\ .25 & .50 & .75 \\ .25 & .50 & .75\end{array}$

Geranium-Ivy Leaved-

P. Crozy-scarlet ….............................. $\quad .15$

Eden Marchii-pink ........................... .15

Souv. de Chas. Turner-pink .......... .15

Jean d'Arc-white ............................. $\quad .15$

General Championnette-scarlet .... $\quad .15$

Lady Washington or Pelargonium .25

Mrs. Robt. Sanford ............................ .25

Crimson King ........................................ $\quad .25$

Mme. Thibaut …………………………... $\quad .25$

Wonder 
Dorothy

.20

Sandiford's Б̈est …............................ .20

Rose scented, should be in every collection

Happy Thought-variegated leaf.... .15

Salleroi-variegated leaf .................. .15

Hydrangea-

Thos. Hogg

Otaksa Montrosa

Oleander-

Pink

White

Frimula-

Sinensis

Obconica

Forbesii (Baby Primrose)

Roses-Specially adapted for house culture-

Bride-white

Bridesmaid-pink

American Beauty-red

American Beauty-red .................... ....

Perle-Yellow

Wooton-red

Golden Gate-pink ........................... ....

Kaiserin-white .....................................

Swansonia-white

........

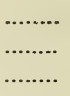

Vinca Variegata-

White

Green

.15

Smilax

Arbutilon-(Daydawn)-A good practical bedder and shapely pot plant. Flowers bright daybreak pink.

Asparagus Plumosus Nanus-Bright green leaves, gracefully arched and as finely woven as silken mesh, retaining their freshness for weeks when cut.

Regonias-(Flowering)-Few families of house plants are so entirely satisfactory in every way as the Begonias. They are rich in color and beautiful in design, and all classes are easily handled under any condition. The flowering varieties are bright with delicate, graceful panicles, set among leaves of endless variety as to shape and coloring; the Rex section, with their gorgeously painted foliage are very rich and showy for decorating purposes; while the large, brilliant flowered Tuberous Rooted class are equally valuable indoors and out. We offer as large and complete a list as any house in the country.

Rex Begonias-(Painted Leaf Begonias)-The high coloring and exquisite markings of Rex Begonias makes them invaluable as decorative plants for house culture. They make excellent plants for baskets and vases, if given plenty of moisture and not exposed to the full rays of the sun. 
Calceolaria-An ornamental plant, producing a mass of beautiful pocket-like flowers early in the spring, and a universal favorite for decorating the greenhouse or conservatory. Our strains have been grown especially for us, and can be relied upon to produce nothing but flowers of the largest size and most brilliant coloring.

Callas-(Ethiopica)-This is the well-known and ever popular White Calla Lily whose chaste, waxen beauty has lent itself for generations to typify purity and sacredness. There is nothing to take its place in decorations for church functions, and its presence in the home is ever an inspiration.

Fuchsias-For window hot plants or for partially shady spots in the garden, these plants, with their gracefully drooping flowers, are held in high favor.

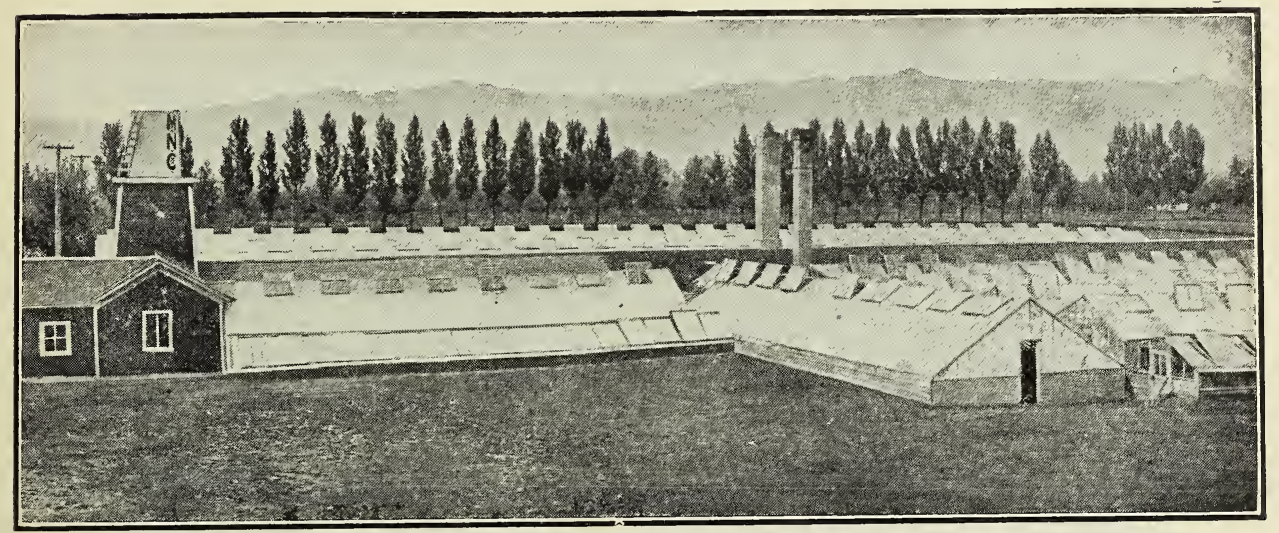

THE GREENHOUSE PLANT.

Primula-(Primrose)-A new species from China. It is one of the most charming plants we know; there could be nothing more graceful or more airy. It is fairly loaded down with flowers of a very pretty shade of light lilac. They are borne in clusters on long, slender but wiry stems, the individual flowers are one-half to three-fourths inches across. The foliage is very attractive, making a handsome setting for the flowers. As a pot plant or for cut flowers it is of the greatest value, of the easiest culture it will become a favorite for the window garden.

Swainsona-(Alba)-The blossoms of these plants are very similar to that of the Sweet Pea. Being of the ever-blooming variety, it is fast becoming a favorite.

Vinca Major Variegata-More of this used for baskets and vases than there is of any other two basket plants. Beautifully rariegated green and white foliage, strong, trailing habit of growth. 


\section{PALMS AND FERNS}

\section{PALMS AND DECORATIVE PLANTS}

Our Palms. We havel paid special attention to this department and the plants we offer for sale are well grown, clean from insects, of large plants for the size of pots they are growing in.

Asparagus-

Each Each Each Each

3 -in. Pot 4 -in. Pot 5 -in. Pot 6 -in. Pot

Plumosus nanus …............................... \$ .25

Tenuissimus ……..................................... .25

Sprengerii ……………………............... .25

Aspidistia, beautiful foliage plant.. ....

Araucaria Excelsa

$\begin{array}{rrr}\$ .50 & \$ .75 & \$ 1.00 \\ .50 & .75 & 1.00 \\ .50 & .75 & 1.00 \\ \ldots \ldots . & 1.25 & 1.50 \\ 1.00 & 2.00 & 3.00\end{array}$

Each Each Each Each

4-in. Pot 5 -in. Pot 6 -in. Pot 7 -in. Pot

Cyprus Alternifolius (Umbrella Plant) .35

Cycas Revoluta (Sago Palm)..............

Dracaena Indivisia ….......................... $\quad .75$

Ficus Elastica (Rubber Plant):..... ....

(Sclected Specimens, $\$ 5$ to $\$ 10$ )

Grevillea Robusta (Silk Oak) ......... $\quad .50$

Kentia Belmoriana ….......................... 1.00

(Selected Specimens, $\$ 5$ to $\$ 10$ )

Kentia Fosteriana …........................ 1.00

(Selected Specimens, $\$ 5$ to $\$ 10$ )

Latania Borbonica (Fan Palm) ........ 1.00

(Selected Specimens, $\$ 5$ to $\$ 10$ )

Pandanus Utilis .............................. .50

Phoenix Canariensis (Date Palm) $\quad .75$ (Extra Fine, $\$ 5$ to $\$ 10$ )

Nephrolepsis Bostonienses (Boston Fern) .75

.75

2.50

1.50

1.50

1.00

4.00

2.50

2.50

1.00

1.50

3.50

4.50

1.50

3.50

4.50

2.00

3.50

4.50

1.50
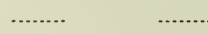

1.00

2.50

Araucaria Excelsa-Deep green, feathery foliage arranged in whorls, rising one above the other at regular distances. It is easily grown and is highly ornamental.

Assorted Ferns-A nice assortment for filling pans, baskets, vases, etc., or for growing on as single specimens in pots.

Dracenas-Used extensively as center plant for vases, baskets, etc. Their leaves contrast nicely with other foliage and flowering plants.

Ficus Elastica-(India Rubber Tree)-Nothing better for table or house decoration. Its dark green, shiny foliage is always handsome, and its constitution is such that it is able to stand the excessive heat and dryness of the ordinary dwelling house without injury.

Kentia Balmoreana-This is, in our estimation, the very best Palm for house culture, as well as the most graceful and handsome. There are few plants that give more satisfaction all the year round.

Kentia Fosteriana-Much like Balmoreana, except that it grows taller, with larger, heavier foliage. 
Latania Borbonica-(Fan Palm)-A beautiful Palm, with large deeply divided, fan-shaped leaves. It is of easy cultivation, and should be in every collection.

Nephrolepis Whitmanii-A new form of the "Plumed Fern." The pinnae subdividing making miniature fronds, which are superimposed on the main fronds, looking as if two or even three were condensed in one.

Phoenix Canariensis-Straight, upright growing plants used for porch decoration and large vase or urn filling; most serviceable and ornamental. We will express strong plants from 7 -inch pots, 28 to 32 inches high.

Pandanus Utilis-(Screw Pine)-A grand decorative plant. Its glossy dark green foliage, gracefully arranged, renders it particularly attractive; fine for centers of viases or baskets, or for growing as single specimens.

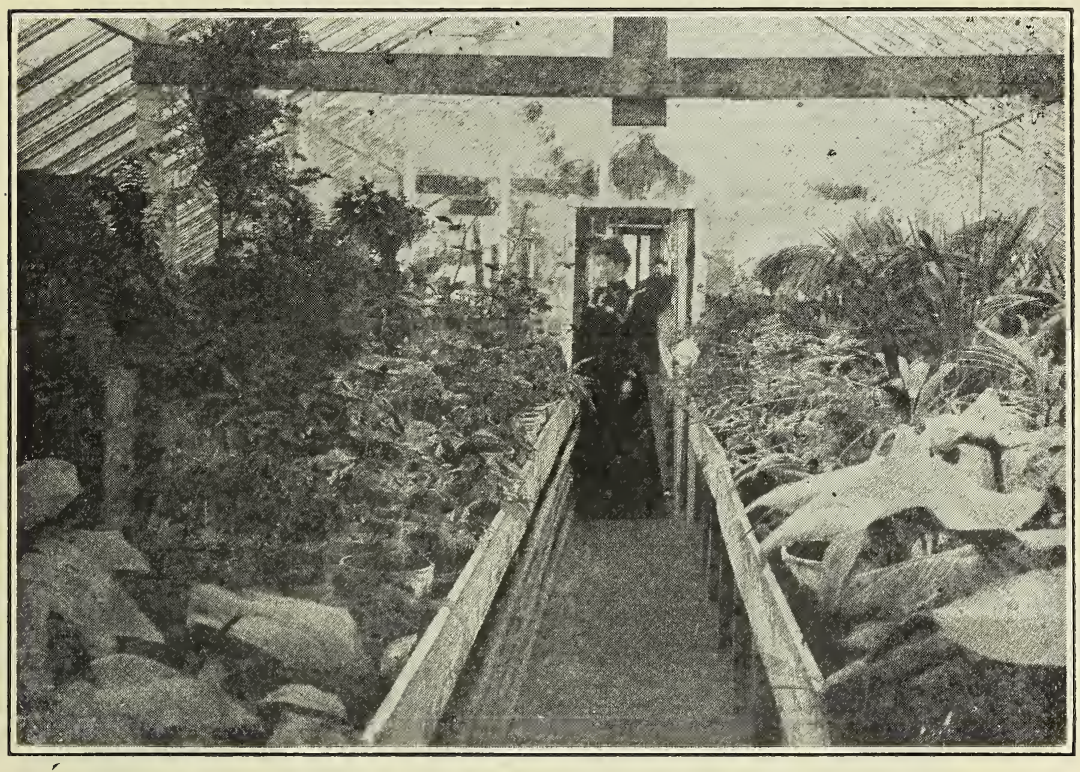

INTERIOR VIEW OF PALM HOUSE

Plumosus Nanus-Used with telling effect in fern dishes, or as a single pot plant; may be trained over windows or small trellises in the house, and is indispensable as a green in floral decorations.

Sprengeri-(Asparagus)-Dense, gleaming trails, ylards long. Very imposing, massed by itself in large cemetery urns.

\section{BULBS}

Tulips for fall planting here around Missoula surpass anything we have ever seen in that line. They bloom about Decoration day. Flowers are 
large, prominent in color and borne on long stiff stems, some bulbs producing as many as three flowers.

Gladiolus

Hyacinths-

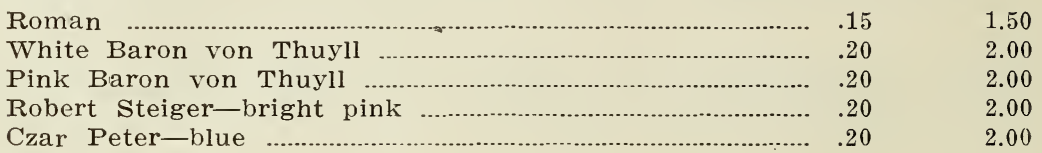

Lilies-

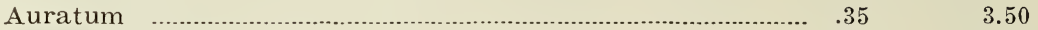

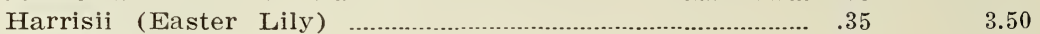

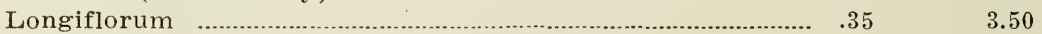

Narcissus-

Von Sion-double yellow …….............................................. $\quad .10 \quad 1.00$

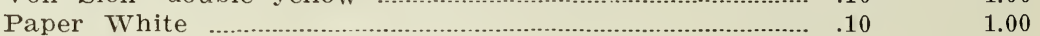

\begin{tabular}{|c|c|c|c|}
\hline Tulips- & Each & Dozen & Per 100 \\
\hline Belle Alliance-scarlet & $\$ .05$ & $\$ .75$ & $\$ 5.00$ \\
\hline Cottage Maid-pink. & $\ldots .05$ & .75 & 5.00 \\
\hline Yellow Prince ................... & .05 & .75 & 5.00 \\
\hline Le Reine-white & .05 & .75 & 5.00 \\
\hline
\end{tabular}

\section{TESTIMONIAL.}

Deer Lodge, Montana, March 27, 1912.

Missoula Nursery Co., Missoula, Mont.

Dear Sir: Received the fern all O. K. in fine shape. Enclosed please find check for same, $\$ 1.50$. Very respectfully yours,

C. H. STEVENS, V. D. S. and D. S. V.,

Deer Lodge, Mont.

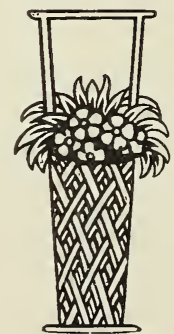




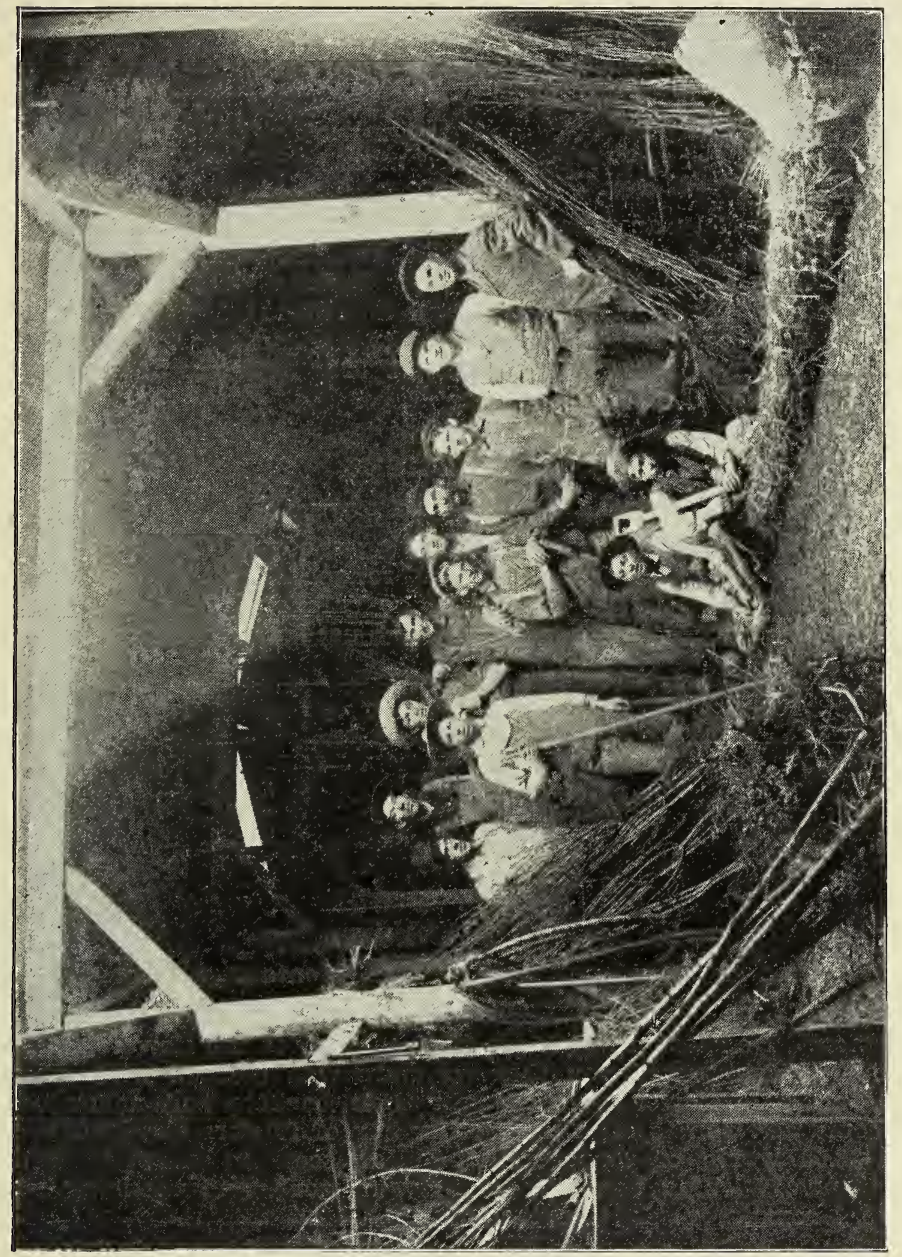

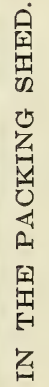




\section{OUR CUT-FLOWER DEPARTMENT}

In this particular we have built up a trade anyone may be proud of. We have 50,000 square feet of glass at your service. We hold the distinction of growing the best carnations in the world, and have shipped our cut flowers from the Atlantic to the Pacific with success, keeping for days after their arrival in perfect condition. Our line in this department offers all the leading stock-Roses, Carnations, Violets, Lily-of-Valley, Snapdragons, Easter Lilies and all other bulbous stock when in season.

Our growers are expert and grow the best; we are proud of them.

The arrangement of decorative and design work is done by mechanics in their line, and have proven to satisfy the most sceptical. Be one of those that we can please.

We ship with safety anywhere, and for the convenience of our city and out-of-town trade that comes to Missoula, we have an up-to-date flower store in the Dixon \& Cowell Block on East Cedar Street. This store was arranged purposely for a flower store and is a beauty. We invite you to make it your stopping place when in the city and enjoy the flowers. Call, write or wire. Store phones: Bell 192, Ind. 526; Nursery and Greenhouse phones: Bell 45, Ind. 1286.

\section{FLORAL DESIGNS}

We can furnish at all times, on short notice, the most artistic floral designs, in a great variety of shapes, including the emblems of all the leading fraternal and secret societies. Prices range from $\$ 2.00$ to $\$ 40.00$ and higher. We can pack floral designs to go safely by express and solicit orders from a distance. The forms generally used are as follows:

$\begin{array}{lll}\text { Wreath } & \text { Gates Ajar } & \text { Broken Wheel } \\ \text { Cross } & \text { Heart } & \text { Scroll } \\ \text { Anchor } & \text { Star on Stand } & \text { Star and Crescent } \\ \text { Broken Column } & \text { Anchor on Stand } & \text { Horseshoe } \\ \text { Pillows } & \text { Lyres } & \text { Harps }\end{array}$

\section{TESTIMONIALS.}

House of Providence, St. Ignatius, Montana, February 3, 1913 Missoula Nursery Co., Missoula, Mont.

Gentlemen: I enclose a check for $\$ 3.00$ to pay for the flowers we bought last month. I wish to tell you that we were well pleased with what you sent us. Our little flower girls thought their baskets had never been so pretty. Would ask you to send us another box of flowers for Friday. I am sure that $\$ 3.00$ worth of them will do. You seem to know so well just what we want. Wishing you success in your work, and thanking you for past favors, I remain,

Respectfully,

\section{SISTERS OF CHARITY, Per SISTER PACOMINS.}

Mr. C. F. Dallman, Missoula, Mont.

Valley Mercantile Company. Hamilton, Montana, January 8, 1913.

Friend Charles: Enclosed find check for $\$ 20.00$, covering amount due you on flowers ordered a few days ago. They were fine and wish to thank 
you for promptness in delivery. Wishing you and yours a happy new year, as well as all the boys, I am, Yours truly,

H. A. STEWART.

Missoula Nursery Co., Missoula, Mont.

Hamilton, Montana, Feb. 21, 1912.

Flowers came fine; they were beautiful. Yours truly,

MRS. J. E. TOTMAN.

Mr. C. F. Dallman, Missoula, Mont.

The Ravalli.

Hamilton, Montana, July 16, 1911.

Dear Sir: Received the flowers and they were fine. Will be in Missoula in a week or ten days and will drop in and settle bill. Your friend,

GEO. W. DREGARD.

Missoula Nursery Co., Missoula, Mont.

Roland, Idaho, December 13, 1912.

Enclosed $\$ 1.00$ account flowers up to December 1. Will you please send me two Hyacinths, one purple and one pink, potted, the first day you have some at the store. The flowers you sent me are beautiful and I appreciate them very much.

MRS. R. O. CLARK.

Montana State College of Agriculture and Mechanic Arts. Bozeman, Montana, April 7, 1912.

Missoula Nursery Co., Missoula, Mont.

Professor Cobleigh tells me that the flowers reached him in perfect condition. Thanking you for your kindness, I am, yours truly,

R. A. BARNES,

407 Eighth Avenue, South.

Missoula Nursery Company.

Deer Lodge, Montana, June 19, 1912.

Dear Sir: I received aster plants all right. Enclosed find stamps for same. I remain yours truly,

W. H. HEINSMAN, Deer Lodge, Mont. 


\section{TRANSPLANTED VEGETABLE PLANTS}

The transplanted vegetable plants we offer for sale are grown from seeds of tested varieties secured from the best seedhouses in the country that handle northern grown seeds, strong healthy plants that will give good results even under adverse conditions. The field of Flat Dutch Cabbage that we have on our grounds this fall, planted with small plants left over after the sale last spring presents a view worthy to see. Heads like wash tubs.

\begin{tabular}{|c|c|c|c|c|}
\hline & Dozen & Per 100 & \multirow{2}{*}{\multicolumn{2}{|c|}{$\begin{array}{r}\text { Per } 1007 \\
\$ 4.00\end{array}$}} \\
\hline Cabbage & .15 & $\$ .75$ & & \\
\hline$(\$ 30.00$ for 10,000$)$ & & & & \\
\hline Cauliflower & .50 & 2.00 & & 10.00 \\
\hline Celery, transplanted .......... & .25 & 1.00 & & $5 \subset 0$ \\
\hline Egg Plant, transplanted & .50 & 2.00 & & 10.00 \\
\hline 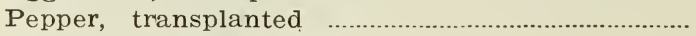 & .50 & 2.00 & & 10.00 \\
\hline 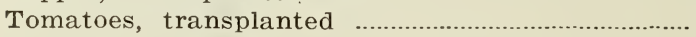 & .50 & 2.00 & & 10.00 \\
\hline
\end{tabular}

\section{CABBAGE}

Danish Ball-Head-(Dutch Winter or Hollander)-The heads are of medium size, solid and deep, averaging in weight nearly eight pounds. Their quality is superior and they are just as solid in spring as when put away in the fall.

Early Winnigstadt-Will grow a hard head under circumstances where most sorts would fail; heads regular, conical, keeps well both summer and winter. Our best gardeners say if they could only grow one sort the Winnigstadt would be their choice.

Large Flat Dutch-Selected and improved, superior to all other flat Dutch in size, sweetness and keeping qualities.

Peerless Drumhead Savoy-When better known will be more generally grown; delicious after slightly frosted.

Peerless Wakefield-The best of all Wakefield; superior strain; earliest, large and sound.

Red Dutch-Used principally for pickling; solid heads, good color.

Surehead-For main crop is unexcelled; large flattish round heads fine and solid; always "heads."

\section{CAULIFLOWER}

Peerless Snowball-Is the best all-round Cauliflower on the market-early or late-for the family or the market garden. It heads where others fail. Its close and compact growing habit permits one-third more to be planted on the same quantity of ground than can be done with other varieties:

\section{KALE}

Dwarfed German Curled-The Kales make excellent greens for fall and are improved when slightly frosted. Cultivate same as Cabbage. Beautifully curled, very hardy.

\section{KOHL RABI}

Early Purple Vienna-An early variety with a bright purple bulb. The leaf and stems being green and tinged with purple. 


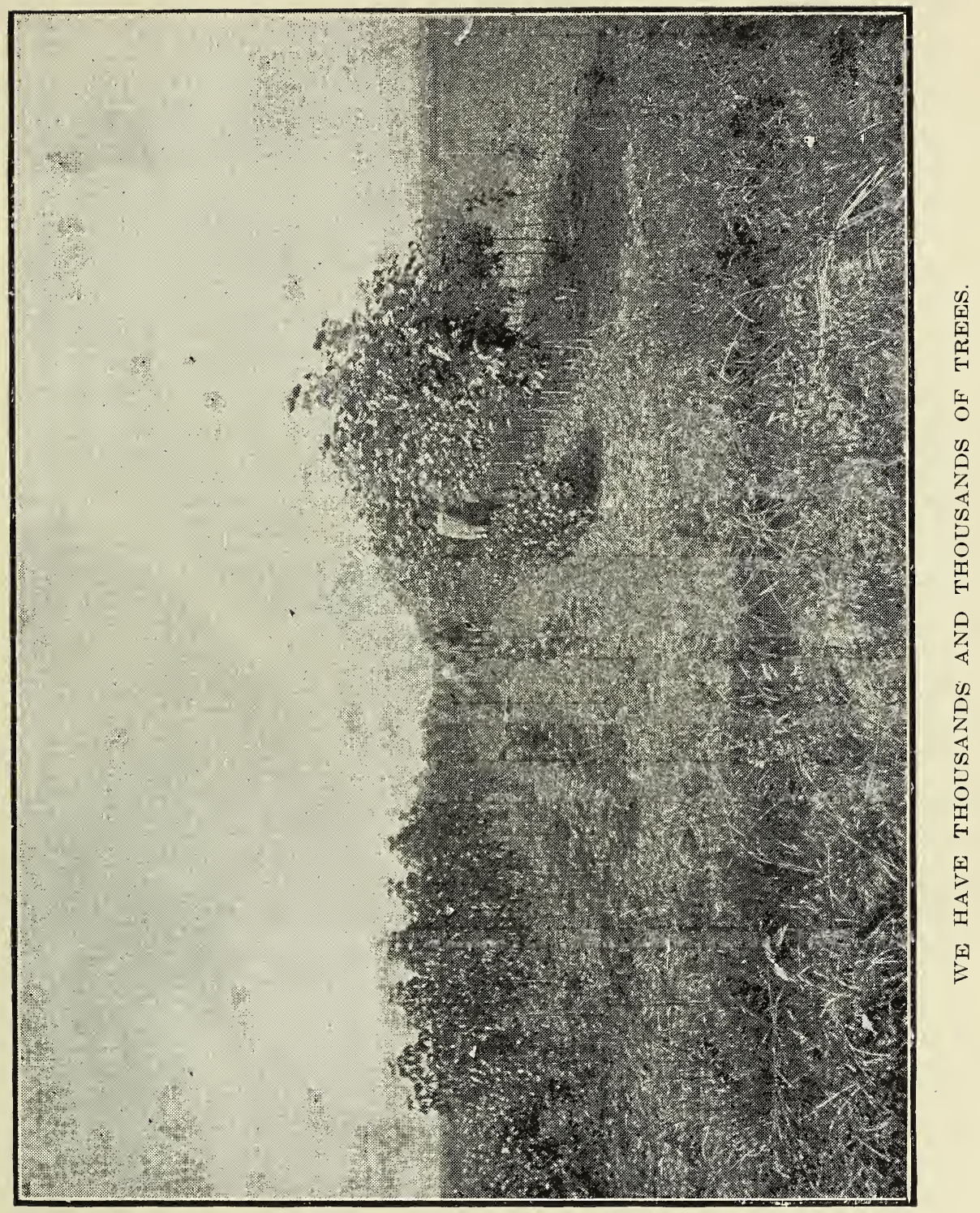




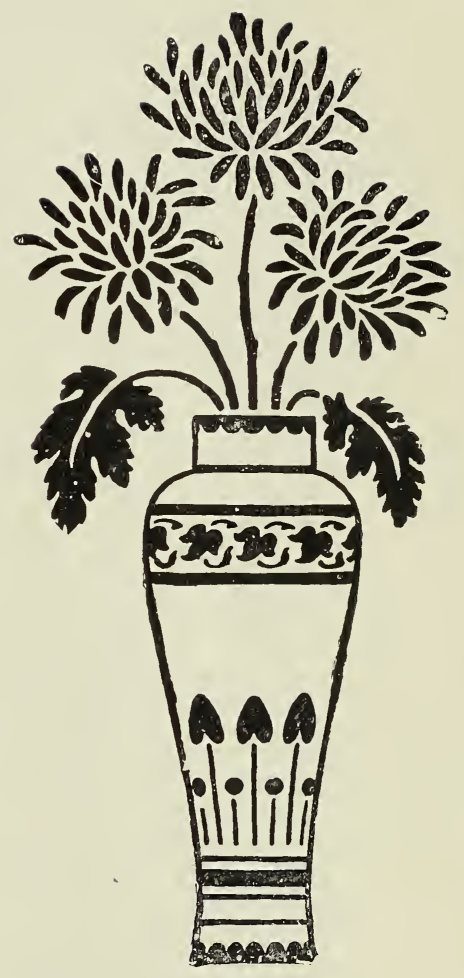


ORDER SHEET-Please Use This Sheet in Ordering Trees and Plants.

\section{MISSOULA NURSERY CO. MISSOULA, MONTANA.}

Please Forward by.

State whether wanted by Mail, Freight or Exp.

Exp. or Frgt. Office

Name

Postoffice

County

State

R. R. or Exp. Line.

\section{AMOUNT ENCLOSED}

Postofice order, \$.

Express M. O. - $\$$.

Bank Draft, - - $\$$.

Cash, - - - - \$.

Stamps, - - $\quad \$$.

Total - - $\quad \$$.

Date

VERY IMPORTANT.-Always write your name and address very plainly; by so doing you will save us much trouble, and save the possibility of delay and mistakes in filling your order. All remittances, if practical, should be made by P. O. or Express Order or Bank Draft. We will not be responsible for money lost if sent in an ordinary letter. One and two cent stamps accepted in sums of $\$ 1.00$ or less.

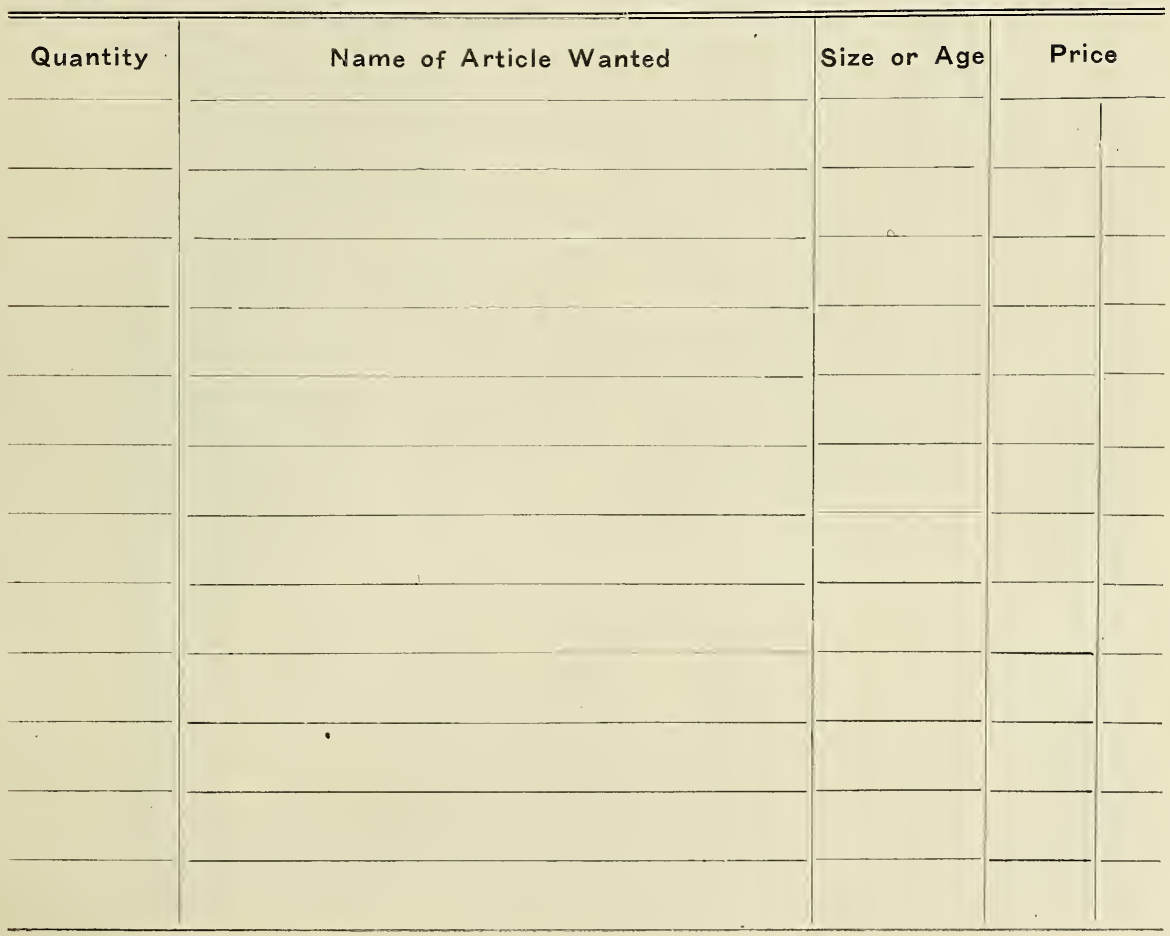




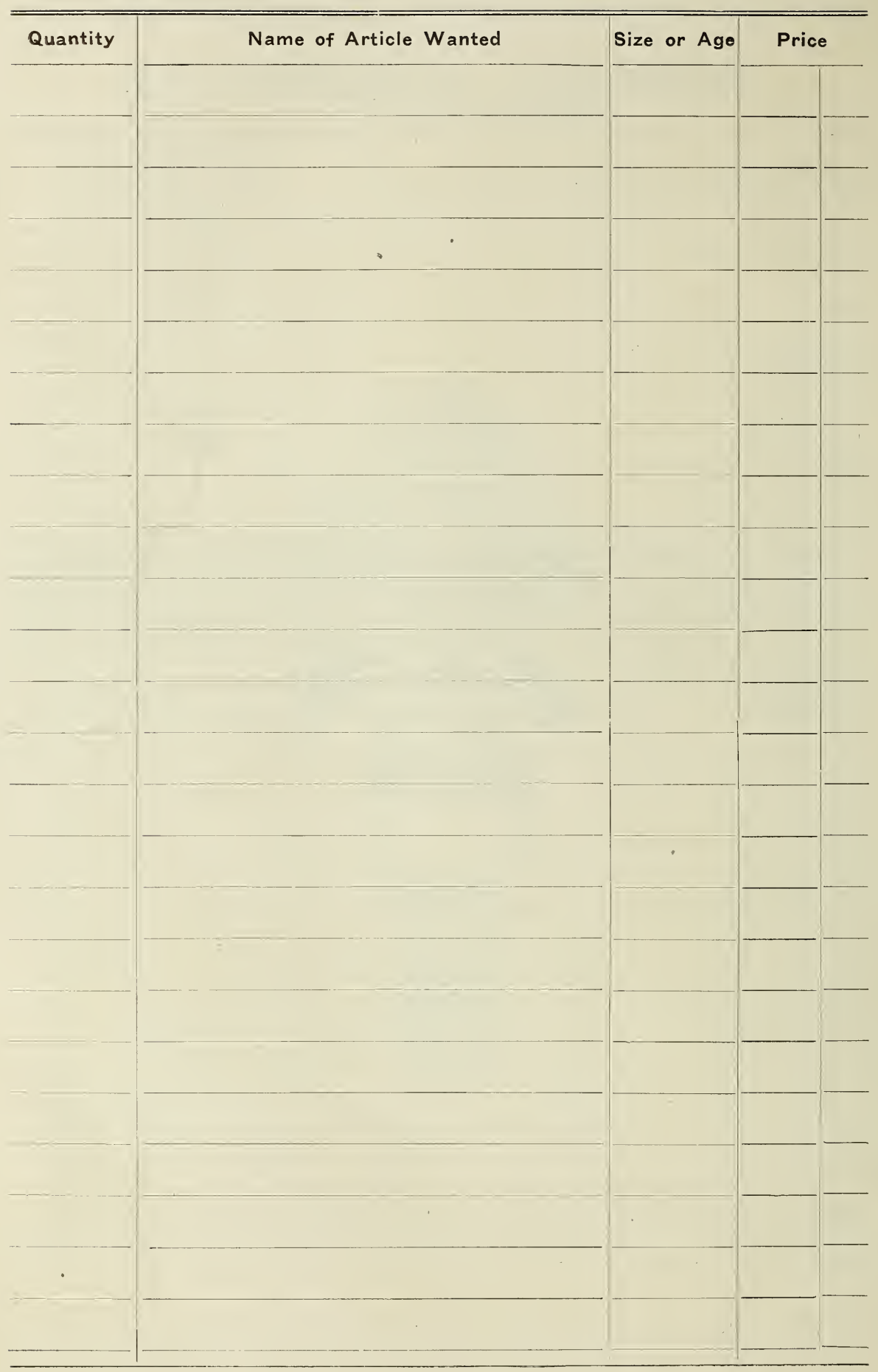




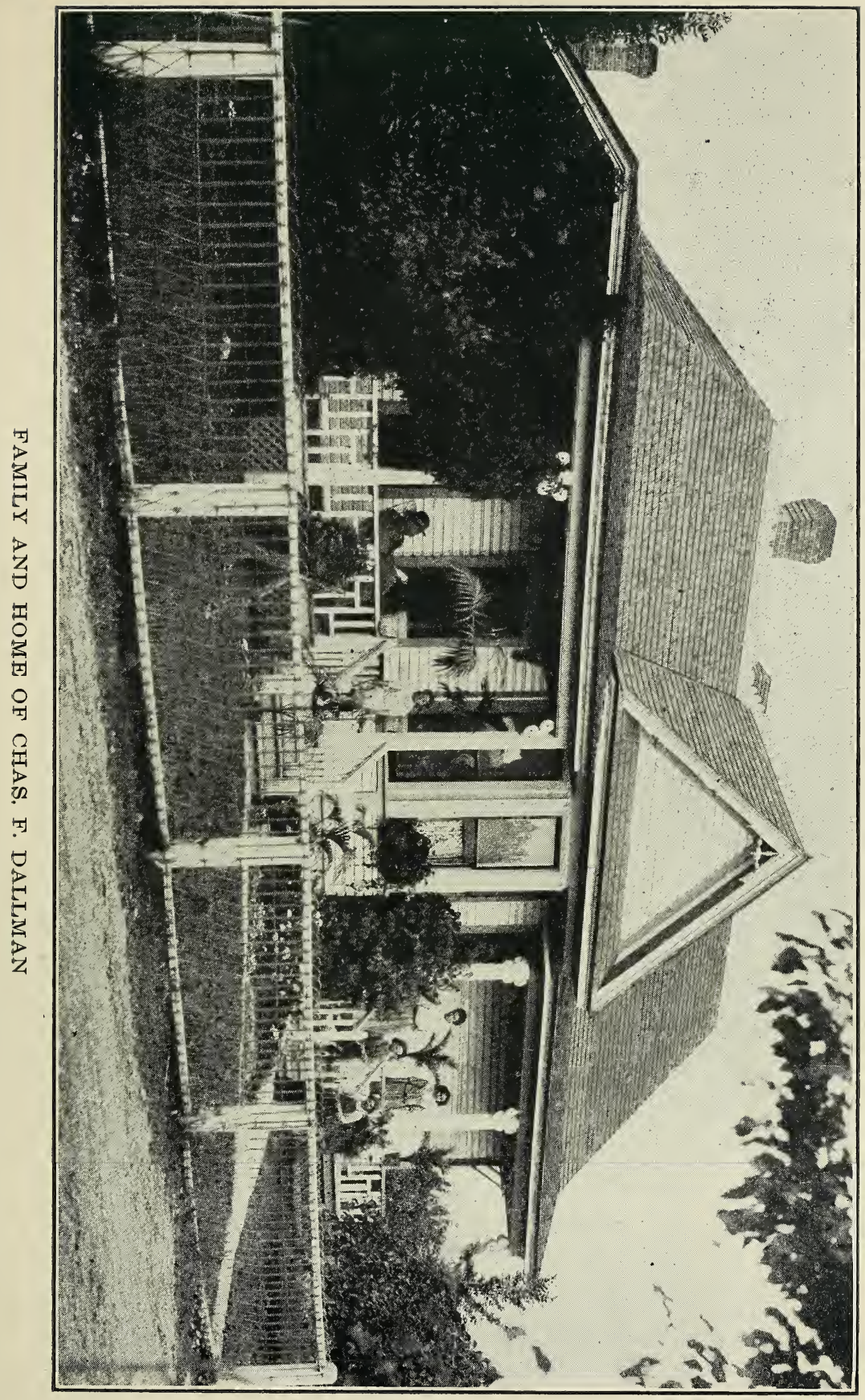




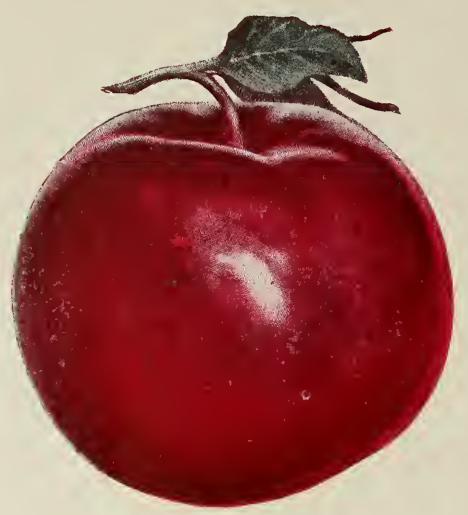

Mclntosh Red-An exceedingly valuable, hardy, Canada sort; medium size, nearly covered with dark red; flesh white, fine, very tender, juicy and refreshing. A good, annual bearer of fair, handsome fruit. Resembles the Fameuse but larger and more hardy and fully equal in quality to this standard sort. Best for Montana planters. November to February.

\section{THE McINTOSH RED}

The MrcIntosh Red ranks as one of the first-class apples; it has been given the highest rating by expert apple judges and it is a ruling favorite in the market. It possesses a distinctive flavor and its fragrant aroma gives it an individuality which ean be claimed by no other apple. The original MeIntosh Red tree, now 124 years old. is yet bearing upon the Mr.Intosh farm near Uttawa, Ont., where it was propagated as a seedling. Thirty-two years ago the first McIntosh trees were planted in the Bitter Root valley. From the date of the maturity of these trees, the McIntosh has been recognized as an apple singularly adapted to the climate and soil of western Montana. Its color, size and fragrance combine with its incomparable flavor to make it one of the most desirable of apples for the market. It is showy and it is excellent in keeping qualities. Its strong individuality makes it worthy of the high place it holds in the list of western apples. We have made a specialty of the propagation of the MeIntosh for years; our stock is select, true to name and absolutely clean. 